


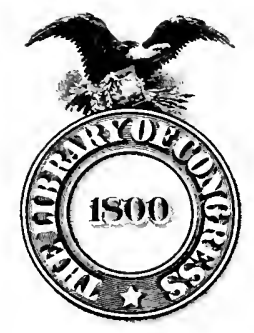








\section{FREDERICK DOUGLASS}

\section{THE ORATOR.}

CONTAINING

AN ACCOUNT OF HIS LIFE; HIS EMINENT PUBLIC SERVICES; HIS BRILLIANT CAREER AS ORATOR; SELE!TIONS FROM HIS SPEECHES AND WRITINGS.

BI

JAMES M. GREGORY, A. M.

Professor of the Latin Language and Literature, Howard University, Washington, D. C.

WITH AN INIRONUCTION BY

W. S. SCARBOROUGH, A. M.,

Professor New Testament, Greek and Literature,

Payne Tileological Seminary, IVilberforce, Ohio.

ILLUSTRATED.

SPRINGFIELD, MASS:

WILLEY COMPANT. 
Entered according to Act of Congress, in the vear $1 \$ 93$,

BY JAMES M. GREGORY, A. I.,

In the Otfice of the Librarian of Congress at Washington, D. C.

MRIVEIEIU PRI:TIZG AND BINHING COMPANY, ELECTROTYYLKS, IRITTEKS AND BINDERS, SHKINGFIKLD, MASS. 


\section{TO THE STUDENTS}

WHO HAVE PASSED UNDER MY INSTRUCTION DURINC, TIIE LAST TWENTY YEARS

\section{THIS BIOGRAPHY \\ OF}

AN EMINENT ORATOR AND A CHAMPION OF HUMAN FREEDOM

IS AFFECTIONATELY INSCRIBED. 




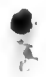

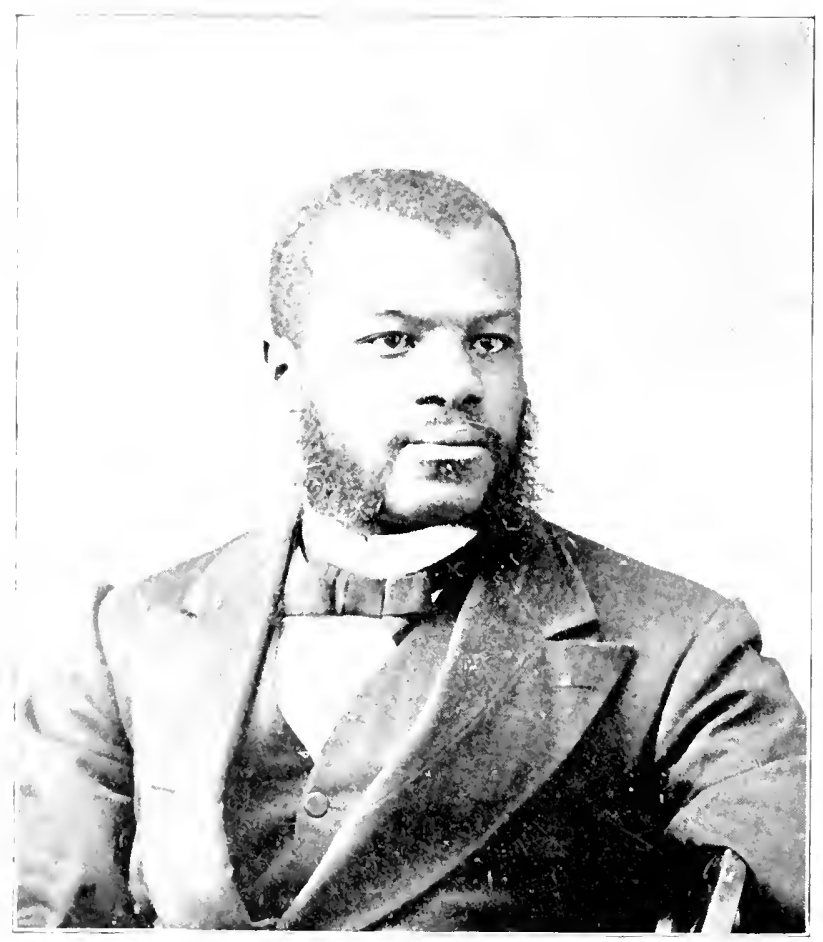

II. S. SCARIOROLGH. 


\section{INTRODUCTION.}

When it was announced that Professor James M. Gregory of Howard University would edit a volume bearing upon some phase of the remarkable career of one of the most remarkable men of our times, the Hon. Frederick Douglass, all became expectant, and felt that a worthier chronicler of a worthier sire would be difficult to find.

Both the writer of this volume and his hero as well are eminent citizens in their respective spheres, and will doubtless receive the respectful attention they merit - the former as a representative of the younger generation, and hence the product of the new dispensation; the latter, of the older generation, but the product of two dispensations, the old and the new.

Professor James M. Gregory by education and by training is in a high degree qualified for the task he has undertaken. Having passed through the Cleveland (O.) city schools, he became a student of Oberlin College, and then a graduate of Howard University, Washington, D. C., where he took high honors.

Immediately upon graduation he was made tutor of mathematics in the preparatory depart- 
ment of his alma mater. After four years as instructor here he was made professor of Latin in the college department, and was for two successive years dean of that department. He was also instructor of political economy and general history.

Professor Gregory is a forcible writer, a fluent speaker, and an acceptable orator. Aside from this he is a man of sound judgment and great executive ability. As an educator he ranks among the first and easily holds his own. He was the first executive officer of the American Association of Educators of Colored Youth, organized under the auspices of the alumni of Howard University, and has since been annually re-elected to that important office. This in itself is conclusive proof of his eminent fitness for the position he holds.

He also served as a member of the board of trustees of the Washington city public schools for six years, and during that time was chairman of the committec on teachers. Here as in other positions he distinguished himself by his efficient service and strict integrity.

The hero of this volume is too well known for even a reference from me, but a few observations will not be out of keeping with the plan and scope of this work. Without exception, the most celcbrated negro now living is the Hon. Frederick Douglass. Born in the lap of slavery and reared 
by slavery's fireside at least until he succeeded in making his escape from bondage, Mr. Douglass has demonstrated beyond contradiction the possibilities of his race even against the most fearful odds. There are other prominent colored men in America-doctors, lawyers, theologians, orators, statesmen, nd scholars-but none of them from a national standpoint has attained the celebrity or the prestige of the "Sage of Anacostia." The pious Mrs. Auld, when she was "learning Fred how to read," little suspected that she, in reality, was shaping the future of him (though then a slave and a member of one of the despised races) who in time was destined to become one of the most distinguished men of his generation. Thus it was.

Mr. Douglass himself tells us, in his autobiography, that he made such rapid progress in mastering the alphabet and in spelling words of three and four syllables, that his old master forbade his wife to teach him, declaring that learning would spoil the best " nigger" in the world, as it forever unfits him to be a slave. He added that he should know nothing but the will of his master, and should learn to obey it. As to Fred, learning will do him no good, but a great deal of harm, making him disconsolate and unhappy. If you teach him how to read, he will want to know how to write, and this accomplished he will be run- 
ning away with himself. Such in substance was his old master's opinion, and that it was a true prediction the life and career of Mr. Douglass, which have been fully told elsewhere, are a sufficient proof.

Mr. Douglass's superior ability as an orator and as a writer was early recognized by the friends of the race, and from that day to this his services in behalf of his people have ever been in demand. On the other hand he has been ready to sacrifice his own best interests for his race, and he has not failed to make the sacrifice. $\mathrm{He}$ is a brilliant orator, a fluent talker, and an interesting conversationalist. He has an excellent memory, and can recall dates and facts of history with perfect ease. A day in his society is a rare treat, a privilege that might well be coveted by America's greatest citizens. The greatness of the man and the inspiration that comes from every word that he utters, make one wonder how it was possible for such a remarkable claracter to have ever been a slave; and, further, how even now it is possible for any discourtesies to be shown him because of his color. It is nevertheless true, however, that this distinguished American citizen must suffer with the rest of his fellows and share like indignities-and all because of his race.

Socrates used to say that all men are sufficiently eloquent in that which they understand. 
Cicero says that, though this is plausible, it is not strictly true. He adds that no man can be eloquent even if he understands the subject ever so well but is ignorant how to form and to polish his speech. We take these views for what they are worth, but venture to add that eloquence is a spontaneous outburst of the human soul.

The cause of the oppressed could not have found a more eloquent defender than Mr. Douglass. Himself oppressed and denied the rights and privileges of a freeman, he felt what he said and said what he felt. The negro's cause was his cause, and his cause was the negro's cause. In defending his people he was defending himself. It was here that the brilliancy of his oratorical powers was most manifest. It was here that he was most profoundly eloquent.

Themistocles, Pericles, and Demosthenes may be said to represent the three ages of Greek eloquence. Themistocles was undoubtedly the greatest orator of Athens before the time of Pericles. "His eloquence was characterized," says Cicero, "by precision and simplicity, penetrating acuteness, rapidity, and fertility of thought."

Pericles was a finished orator, the most perfect type of his school, and was regarded by Cicero as the best specimen of the oratorical art of Athens -eloquentissimus Athenis Pericles. But the third representative was one whose oratorical greatness 
seemed destined to remain forever uneclipsed. In Demosthenes political eloquence in Greece culminated. He was without doubt the greatest of all Athenian orators, and, to use the language of Longinus, "his eloquence was like a terrible sweep of a vast body of cavalry." It mowed down everything before it.

Certainly a noble ambition, if, as we learn elsewhere, the sole purposes for which he labored were to animate a people renowned for justice, humanity, and valor; to warn them of the dangers of luxury, treachery, and bribery, of the ambition and perfidy of a powerful foreign enemy; to recall the glory of their ancestors, to inspire them with resolution, vigor, and unanimity, to correct abuses, to restore discipline, to revive and restore the generous sentiments of patriotism and public spirit. Laudable as was this ambition, it was no more laudable than that which actuated Frederick Douglass during all the years of his active life.

The scathing invectives and fiery eloquence of Mr. Douglass were the inevitable outcome of a soul longing for freedom in all that the term implies, not only for himself but for an oppressed race. His sole purpose was to stir the hearts of the American people against the system of slavery and color prejudice; to touch the philanthropic chord of the nation so as to induce it to recognize the brotherhood of man and the father- 
hood of God. A tremendous task was his, but he never gave up the struggle. Day and night he pleaded for freedom, for citizenship, for equality of rights, for justice, for humanity. Could a higher sentiment of philanthropy and patriotism pervade a human soul than this?

Lincoln, Grant, Sumner, Morton, Phillips, Garrison, Garfield, Blaine, Wilson, Conkling, Wade, Thaddeus Stevens, Chase, and other advocates of freedom have all passed away, but they have left behind them influences that survive. The echoes of their words in senate chambers and public halls will resound throughout all ages; their heroic lives and their philanthropic deeds will live when time shall have passed into eternity. These, however, were of Anglo-Saxon extraction. On the other side stands one of African extraction, to some extent their co-laborer, the hero of this volume. In point of ability and all the virtues that go to make up a well rounded citizenship Mr. Douglass compares well with them allthe only difference being that they represent white American and he black America.

This grand old patriot will always live in the hearts of his countrymen as one of the greatest of America's noblemen. His hard-fought battles and victories won will prove an incentive to generations yet to come. His virtuous life and noble deeds will always remain to warn us to 
bestir ourselves in the interest of manhood rights, in the interest of justice to all men regardless of color or nationality.

\section{W. S. SCARBOROUGH.}

WilberFORCE, O., April I8, 1893. 



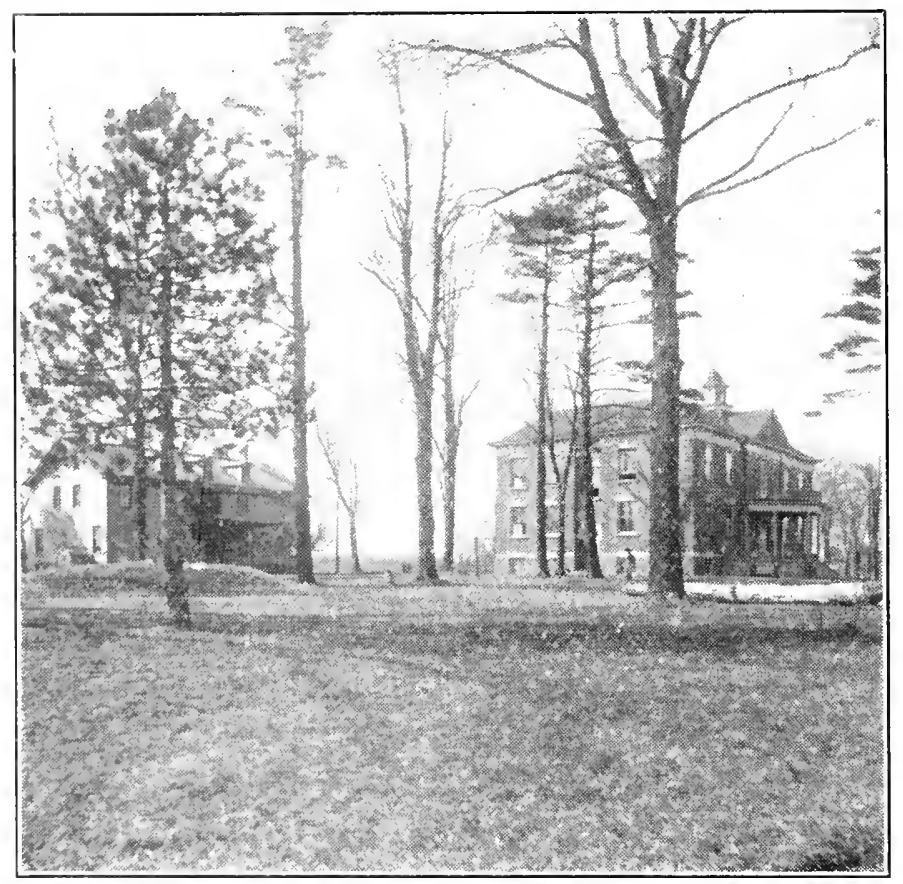

Manual Training and Industrial School for colored Youth, Ironsides, Burdentown, N. J. 
PREFACE TO THE FOURTH EDFTION.

THE first thirteen chapters of this book were written while Mr. Douglass was living; and published in I893. The last chapter was added after his death in 1895 , at which time a second edition was issued, and afterwards a third.

It is gratifying to the anthor that the work has found favor with the public, and that there is an increasing desire on the part of the youth to know more of this remarkable man. In many of the public schools for colored children the birthday of Frederick Douglass, February gth, is regularly observed, and at these times the lessons from his life are impressed upon the young. It is always a hopeful sign of the development of a people when the young men and women find in their own race those whose characters are worthy of study and of initation.

Some years ago, in Washington, Dr. Sanders, president of Bidlle University, Charlotte. North Carolina, remarked to the writer that a young man came to him to rehearse his oration for commencement. He noticed that all the examples of hravery and heroism were taken from 
the white race and he asked him why he had not taken some of his models from his own race. The student replied that he did not know of any negro in history possessing these qualities in an unusual degree. The Doctor arose, took down a book from a shelf in his library, and opened to the astonished gaze of the young man chapters headed "Toussaint L'Ouverture" and "Chrispus Attucks." The oration was rewritten, and in the student was created a higher conception of courage and respect for members of his own race and in his bosom burned a new flame of pride and confidence in his powers.

In further attestation of the place Mr. Douglass holds in the affections and memory of the people, his old home, Cedar Hill, at Anacostia, District of Columbia, by act of Congress, under the direction of the Frederick Douglass Historical Association, has been turned into a permanent memorial. Hither will come the people in loving remembrance of the Great Douglass who did so much to break the chains of slavery that bound and degraded his race, and who, after the abolition of slavery, was untiring in his efforts to secure for them all the rights and privileges of citizens.

The writer was engaged as instructor and professor in Howard University from $\mathrm{I} 872$ to I 896 , and has been principal of the Manual 
IREFACE.

Training and Industrial School for Colored Youth at Ironsides, Bordentown, New Jersey, since IS97. He finds here, as at Howard, the influence of the life of Mr. Douglass continues to impress itself upon him and to give him inspiration in his work of training and elucating the young.

JAMES M. GREGORY, Manual Training and Industrial School for Colored Youth at Ironsides, Bordentown, N. J.

May 15, 1907. 



\section{PREFACE.}

IT has seemed to the author that a volume which should give the important incidents in the life of Frederick Douglass, and which should treat of him as orator and thinker, would find favor with the public. His speeches and lectures have been carefully examined, and the best selections from these incorporated in the biography.

No pretensions are made to the discovery of new facts. Where practicable Mr. Douglass is permitted to speak in his own language. Most of the quoted passages are from that inimitable autobiography, "The Life and Times of Frederick Douglass," and are here introduced by permission of Mr. Douglass, and the publishers, Messrs. De Wolf, Fiske \& Co. Such other publications have been consulted as were deemed necessary.

The main purpose of this book is one of usefulness. If it shall be instrumental in leading our youth to study the character of this remarkable man and to draw from it lessems that will wree them to high and noble effort, the time and latur spent in its preparation will not have been in ram.

HowaRD UNIVERSITY, March 24, 1893. 


\section{CONTENTS.}

CHAPTER I.

PAGE

Birth and Early Life.-Escape from Slavery,

CHAPTER II.

Career as an Anti-Slavery Agitator.-First Visit to Great Britain, . . . . 28

CHAPTER III.

Editor of the "North Star."-Connection With JohN BROWN, . . . . 32

CHAPTER IV.

Second Visit to England. - The War of the Rebellion, · · . . . . 50

CHAPTER V.

Continued Literary Efforts. - Freedmen's Bank. - Official Career in Washington.-Visit to His Oli Maryland Home, 54

CHAPTER VI.

Banquet in Recognition of His Public Services.-The Douglass in IHs Halle, . 6y

\section{CHAPTER VII.}

Visit Abroad.-Return Home ant Reception.Minister Resident ani Consul General TO HaYTi, 


\section{C.HAPTER IX.}

Extracts from His Speeches and Lectures, .

\section{CHAPTER X.}

Extracts From His SpeEches and Lectures Continter,

\section{CHAPTER XI.}

Extracts from His Speeches and Lectures Cuncluded, . . . . . . . .

\section{CHAPTER XII.}

Members of the Douglass Failly,

\section{CHAPTER XIII.}

His Home-Personal Traits and CharacterISTIC: .

\section{CHAPTER XIV.}

Death of Frenerick Douglass and Funeral Services at IVashington, D. C.,

CHAPTER XV.

Obsequies a R Ruchester, N. Y., . 


\section{LIST OF ILLUSTRATIONS.}

PORTRAITS.

AUthor's PORTRait.

FRETERICK DUTiIASS (as a young man).

fikEDERJCk DhCGLASS (as an old man).

FREDERUK TWURLASS, JR.

CHARtES R. IOOUGLASS.

LEWTS H. POUGLASS.

Mks. R. D. SPRAGUE (Daughter of Frederick Douglass).

TOHN BROWN.

JAIJES A. GARFIELD.

U. S. GRANT.

TOHN M. HARLAX.

RUTHERFORD B. HAYES.

HYPPOLITE.

ABRAHAM LINCOLN.

II. S. Scarborough.

CHARIES SUMNER.

Mrs. AMY POST.

Robert Gould Shaw.

MAYOR F. S. CUNNINGHAM.

VIEIVS.

Residence, uf Frederick Douglass (Cedar Hill, Anacostia, D. C.).

FRONT VIEW.

SIDE VIEW.

"Mr. DOUGLass' DEN."

THE OLD Pust HuSF. (Headquarters of the Underground Railroad).

Cellar in the Oli post House.

PARlor of THE Old POST House.

Freinerick Douglass' Old POST OfFice (where the North Star was printed).

THE DOUGLASS FINIRAL.

THF, LINE OF MARCH.

THE PROCISSION.

IN Front OF THE CHURCh.

inside the Church. 



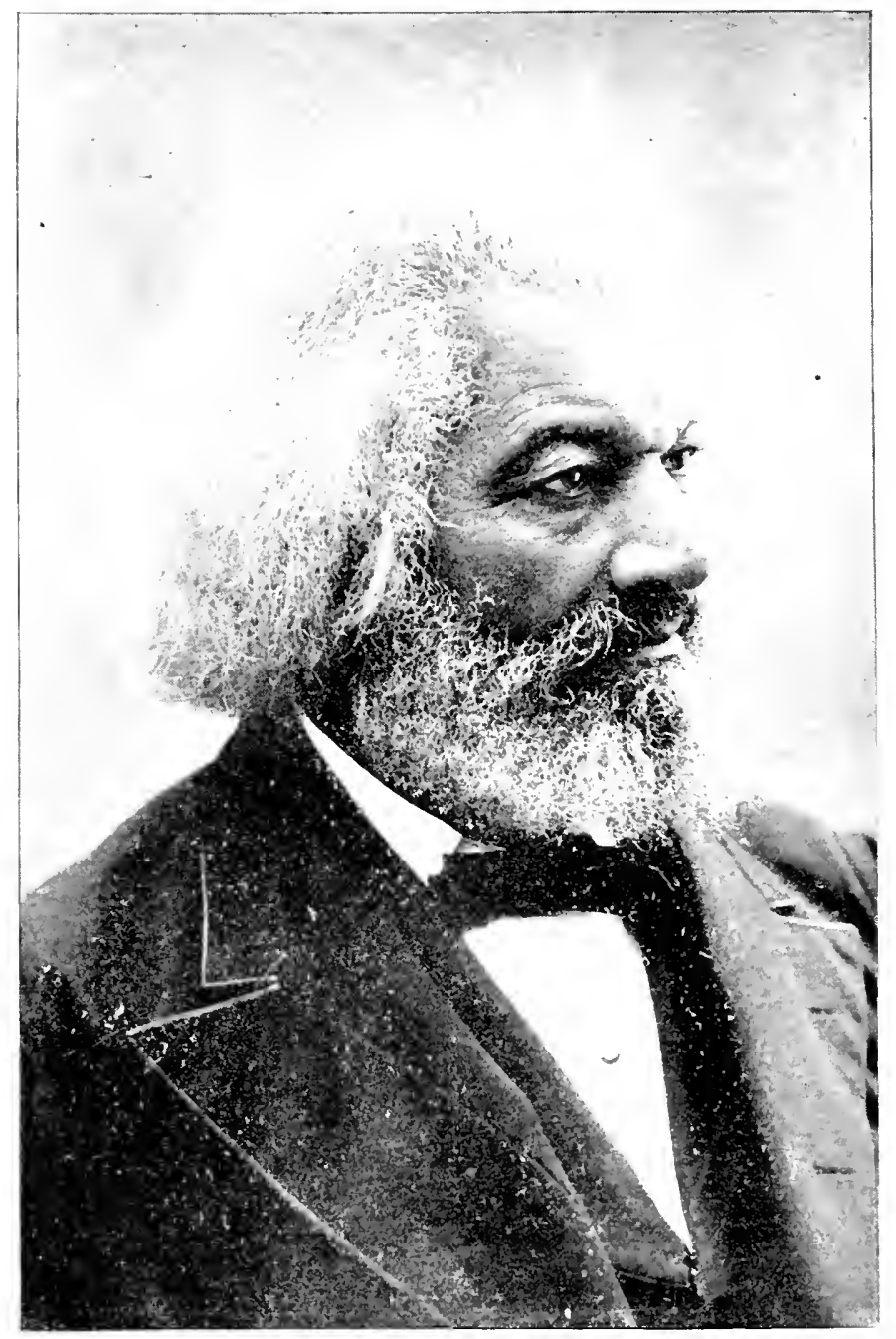

FREIOEKICK IO)U(GLASS. 


\section{FREDERICK DOUGLASS, THE ORATOR.}

\section{CHAPTER I.}

Birth and Early Life.-Escape from Slavery.

Among the great men America has produced whose achievements will be narrated to posterity and remembered, is Frederick Douglass. His name is so identified with the anti-slavery movement that no account of this eventful period of our national existence will be complete in which the historian neglects to tell of the remarkable career of this eminent man, and to assign him that place which the services he has rendered his race and mankind deserve.

It is often argued that great crises produce great men, and, conversely, great men bring about great crises, but it will be found difficult to establish the truth of either of these propositions to the exclusion of the other, inasmuch as the forces that operate and co-operate in each are factors of a common product. Observation shows that when the exigencies of the times have demanded leaders, those were chosen whose training and experience fitted them for the particular 
emergency. An ancient author relates that when an inhabitant of the barren island Seriphus in the Egean sea, to which the Romans banished their criminals, claimed. that Themistocles had acquired distinction not through his own glory but through that of his native Greece, Themistocles replied: "Neither, by Hercules, if I had been a man of Seriphus, should I ever have been eminent, nor, if you had been an Athenian, would you ever have been renowned."

It sometimes happens that one circumstance or chain of circumstances singles out a man from among his fellowmen and places him in the number of those whose fame shall endure and grow brighter with time. Father of his Country is the title which appropriately belongs to Washington, because, under his leadership, success crowned our arms in the war for independence. The fame of John Brown is made secure by his raid upon Harper's Ferry and his subsequent martyrdom. If the other acts of President Lincoln be forgotten, the one act of signing the Emancipation Proclamation will insure him the remembrance of posterity. Hero of Appomattox is the designation by which Grant will be known through the ages. The name of Frederick Douglass will survive as the fugitive slave who became one of the most eloquent orators as well as profound thinkers of his time. 
Frederick Douglass was born at Tuckahoe, in Talbot county, Maryland, in February, 1817 . The place was not distinguished either for the fertility of the soil, the beauty of the surroundings, or the thrift and intelligence of its inhabitants. His mother was Harriet Bailey. Of his father he has no knowledge. He lived with his grandmother till he was five years of age, and during that period saw his mother only a few times. He was now taken to the home plantation of Colonel Lloyd, about two miles from his birthplace. Here, along with the other children, he was placed in the care of Aunt Katy, whom Mr. Douglass describes as a cruel and ill-natured person.

At the age of ten he was sent to Baltimore to live with Mr. Hugh Auld, whose wife, Mrs. Sophia Auld, was his first teacher, and she continued her instructions until objection was made to it by her husband. Frederick, however, found other means of accomplishing his desire. Having procured a spelling book he learned to rcad through the assistance of his white playmates whom he met in the streets. When about thirteen years of age he bought a book entitled the "Columbian Orator," with money earned by blacking boots. The speeches of Sheridan, Lord Chatham, William Pitt, and Fox, which he read in this book, increased his information and supply of words, en- 
abling him to give expression to the thoughts that now began to form in his mind. By reading and observation he was led at this early age to understand something of the wicked system of slavery.

About this time he became acquainted with a pious man by the name of Lawson, whom he visited at his home. Father Lawson inspired him in his search for knowledge by the assurance, "The Lord has a great work for you to do, and you must prepare yourself for it." It was soon after his acquaintance with this good man that he learned to write by copying letters with chalk on fences and pavements. Left in charge of the house he wrote upon the vacant spaces of copy books which his young master had used in school. He further continued his studies, seated in the kitchen loft late at night when the other inmates of the household were asleep, in transcribing from the Bible, the Methodist hymn book and other books, a barrel head serving him the purpose of a table.

Upon the death of his former owners Frederick became the property of Mr. Thomas Auld, who then resided at St. Michael's. Here he was cruelly treated, having the coarsest food, and not enough of that to satisfy the cravings of his appetite. Several difficulties occurred between $\mathrm{Mr}$. Auld and Frederick, in consequence of which Mr. Auld sent him to Covey, a notorious "negro- 
breaker" in the neighborhood, for discipline. He had not been long with Covey before he was subjected to the greatest cruelty. The details of one difficulty between them we give in Mr. Douglass' own language, as it serves to show the methocls pursued in "breaking" slaves, and at the same time furnishes an example of his powers of narration, for which he is especially distinguished.

"Mr. Covey sent me, very early in the morning of one of our coldest days in the month of January, to the woods, to get a load of wood. He gave me a team of unbroken oxen, telling me which was the inside ox, and which the off-hand one. He then tied the end of a large rope around the horns of the in-hand ox, and gave me the other end of it, and told me, if the oxen started to run, that I must hold on upon the rope. I had never before driven oxen, and of course I was very awkward. I, however, succeeded in getting to the edge of the woods with little difficulty, but I had got a very few rods into the woods, when the oxen took fright and started full tilt, carrying the cart against trees, and over stumps, in the most frightful manner. I expected every moment that my brains would be dashed out against the trees. After running thus for a considerable distance, they finally upset the cart, dashing it with great force against a tree, and threw themselves into a dense thicket. How I escaped death, I do 
not know. There I was, entirely alone, in a thick wood, in a place new to me. My cart was upset and shattered, my oxen were entangled among the young trees, and there was none to help me. After a long spell of effort, I succeeded in getting my cart righted, my oxen disentangled, and again yoked to the cart. I now proceeded with my team to the place where I had, the day before, been chopping wood, and loaded my cart pretty heavily, thinking in this way to tame my oxen. I then proceeded on my way home. I had now consumed one-half of the day. I got out of the woods safely, and now felt out of danger. I stopped my oxen to open the wooden gate; and just as I did so, before I could get hold of my ox-rope, the oxen again started, rushed through the gate, catching it between the wheel and the body of the cart, tearing it to pieces, and coming within a few inches of crushing me against the gate-post. Thus twice, in one short day, I escaped death by the merest chance. On my return, I told Mr. Covey what had happened, and how it happened. He ordered me to return to the woods again immediately. I clid so, and he followed on after me. Just as I got into the woods, he came up and told me to stop my cart, and that he would teach me how to trifle away my time, and break gates. He then went to a large gum-tree, and with his ax cut three large switches, and, 
after trimming them up neatly with his pocketknife, he ordered me to take off my clothes. I made him no answer, but stood with my clothes on. He repeated his order. I still made him no answer, nor did I move to strip myself. Upon this he rushed at me with the fierceness of a tiger, tore off my clothes, and lashed me till he had worn out his switches, cutting me so savagely as to leave the marks visible for a long time after. This whipping was the first of a number just like it, and for similar offenses."

After the affair just narrated, Frederick's sufferings were increased, and he was driven to such desperation by the treatment of Covey, that he determined to defend himself. In the next encounter which they had Covey was handled so roughly by the young man that he never again raised his hand against him. This conflict with Covey had a most inspiring effect upon the youth. By resistance he asserted his manhood, increased his own self-respect, and confidence in himself. From this day on he was never whipped while in slavery, though he had several fights.

Leaving Covey in January, I 834 , Frederick went to live with Mr. William Freeland, whom he found to be a very good man. He for more than a year after that time conducted a Sabbathschool, where he taught his fellow slaves to read. He also devoted three evenings in each week to a 
similar purpose. While at Mr. Freeland's the following year he made up his mind to make an attempt to secure his liberty. He consulted with those slaves who he believed would be willing to co-operate in this movement with him. But they had in mind no definite place to which they could flee and enjoy their freedom. Mr. Douglass has beautifully and graphically described the thoughts that passed through their minds at the time they were planning to run away. Here is what he says: "At every gate through which we had to pass we saw a watchman; at every ferry a guard; on every bridge a sentinel, and in every wood a patrol or slave-hunter. We were hemmed in on every side. The good to be sought and the evil to be shunned were flung in the balance and weighed against each other. On the one hand stood slavery, a stern reality, glaring frightfully upon us, with the blood of millions in its polluted skirts, terrible to behold, greedily devouring our hard earnings and feeding upon our flesh. This was the evil from which to escape. On the other hand, far away, back in the hazy distance, where all forms seemed but shadows under the flickering light of the north star, behind some craggy hill or snow-capped mountain, stood a doubtful freedom, half frozen, beckoning us to her icy domain. This was the good to be sought. The inequality was as great as that between certainty 
and uncertainty. This in itself was enough to stagger us; but when we came to survey the untrodden road and conjecture the many possible difficulties, we were appalled, and at times, as I have said, were upon the point of giving over the struggle altogether. The reader can have little idea of the phantoms which would flit in such circumstances before the uneducated mind of the slave. Upon either side we saw grim death, assuming a variety of horrid shapes. Now it was starvation, causing us, in a strange and friendless land, to eat our own flesh. Now we were contending with the waves and were drowned. Now we were hunted by dogs and overtaken, and torn to pieces by their merciless fangs. We were stung by scorpions, chased by wild beasts, bitten by snakes, and, worst of all, after having succeeded in swimming rivers, encountering wild beasts, sleeping in the woods, suffering hunger, cold, heat, and nakedness, overtaken by hired kidnapers, who, in the name of law and for the thrice-cursed reward, would, perchance, fire upon us, kill some, wound others, and capture all. This dark picture, drawn by ignorance and fear, at times greatly shook our determination, and not unfrequently caused us to

". Rather bear the ills we had,

Than flee to others which we knew not of." "

But just as they were about to start they found 
that they had been betrayed, and their plans revealed. As a result of this discovery they were all bound with cords and driven off to the Easton jail. The slaveholders now demanded that Frederick be removed from the neighborhood. Captain Auld therefore sent him back to Baltimore to live with his brother Hugh, where he might learn a trade. Soon after going there he was hired to Mr. William Gardner, a ship builder, for the purpose of learning to calk vessels. He made no progress in the business at this place. The white apprentices thought it degrading to work with a slave, and on one occasion made an assault upon him. In the struggle which ensued Frederick, although bruised and severely beaten, resisted as best he could; but at last had to yield because of the great numbers against him. He was afterwards hired to Mr. Walter Price, where he learned calking, and soon commanded the highest wages.

During his leisure hours he reflected much upon his condition; and the more he reflected, the more he hated slavery, and the more discontented he became. He therefore determined to make another attempt to secure his liberty, and, with this end in view, obtained from a friend a "Sailor's protection," which in this instance served the purpose of free papers. Disguised as a sailor, he left Baltimore, September 3, I $s_{3} 3$, now 
twenty-one years of age, and made his way to New York, where he was introduced to Mr. Ruggles, secretary of the New York Vigilance Committce. As soon as she could be sent for, his affianced wife, Anna, came on, and they were married by the Rev. J. W. C. Pennington, of the Presbyterian church. Acting upon the advice of Mr. Ruggles, he went to New Bedford, and was kindly received by Mr. Nathan Johnson. In slavery Frederick's name was Frederick Augustus Bailey. At the suggestion of Mr. Johnson his name was now changed to Frederick Douglass, by which title he has ever since been known. In New Bedford he found employment in putting away coal, sawing wood, moving rubbish, working on the wharves, and in a brass foundry; and thus earned the means to support his family. It was here that he became a subscriber of Mr. Garrison's paper, the Liberator. Mr. Douglass says this paper took the place in his heart, "second only to the Bible." Not long after subscribing for the Liberator, he had the pleasure of hearing Mr. Garrison himself, and from this time on entertained for the distinguished agitator the highest admiration. By reading the Liberator he came in possession of the principles of the abolition movement. The spirit that animated its friends in their efforts to put down human slavery had already been awakened within him. 


\section{CHAPTER II.}

Career as an Anti-Slavery Agitator.-First Visit to Great Britain.

ON the i ith of August, I 84I, an anti-slavery convention was held at Nantucket. Many distinguished abolitionists were present, among whom was Mr. Garrison. Mr. Douglass had come to the convention that he might learn something further of the principles and measures of these reputed fanatics. Being invited to speak he at first declined to say anything. Urged by a friend, he at last came forward with great reluctance and embarrassment, and addressed the meeting. So great was the impression made upon the audience by his eloquent words, that it was the means of opening to him that field in which he has won so many laurels as a platform speaker and orator. Not long after this he was appointed a lecturing agent of the Anti-Slavery Society.

In the same year he made speeches in Rhode Island, where an attempt was made to set aside the old colonial charter by a constitution in which was a provision to deprive colored men there of the elective franchise. At this time there were very strong prejudices against the negro in that 
state. Speaking of his work in Rhode Island, Mr. Douglass says: "In Grafton, I was alone, and there was neither house, hall, church, nor market-place in which I could speak to the people, but, detcrmincd to speak, I went to the hotel and borrowed a dinner bell, with which in hand I passed through the principal streets, ringing the bell and crying out, 'Notice! Frederick Douglass, recently a slave, will lecture on American slavery, on Grafton common this evening at seven o'clock. Those who would like to hear of the great workings of slavery, by one of the slaves, are respectfully invited to attend.' 'This notice brought a large audience, after which the largest church in town was open to me."

In what is known as the "hundred conventions," which in the year I $S_{43}$ were held in New Hampshire, New York, Vermont, Ohio, Indiana, and P'ennsylvania, Mr. Douglass took an active and leading part. He experienced the same difficulty in procuring places in which to speak, and often he was compelled to hold his meetings in the open air. A memorable meeting was held at Pendleton, Indiana. No building of any kind could be procured in which to hold the assemblage, and consequently they convened in the woods near by, where an infuriated mob rushed upon and assaulted them. Mr. Douglass, in attempting to fight his way through the crowd, 
had his arm broken, was knocked down, and left unconscious by his cowardly assailants. At Buffalo, where one of these meetings was convened, he took part in a convention of colored men assembled about the same time to discuss questions of importance to the race.

Mr. Douglass, some time after his speech at the Nantucket convention, wrote an account of his life and published it in pamphlet form. These pamphlets were widely circulated and read, and they, together with the addresses he had clelivered as agent of the Anti-Slavery Society, attracted to himself the attention of the country. For this reason he was now in danger of being seized and carried back into slavery. With the view of avoiding the possibility of such a misfortune, he was induced to seek refuge abroad.

The visit which Mr. Douglass at this time made to Great Britain was of much benefit to him, as it gave opportunity of seeing the great. cities of the mother country, of studying the character of its people and their institutions, of hearing the great orators of the age, and of meeting many eminent literary and educated men. He heard in parliamentary debate, Cobden, Bright, Peel, Disraeli, O'Connell, Lord John Russell, Lord Brougham, and other renowned statesmen. Of all these distinguished men, he thought Lord Brougham the best speaker. He was kindly re- 
ceived and hospitably entertained by eminent men in England, Scotland, and Ireland. On the 7 th of August, I 846 , the World's Temperance Convention was held in Covent Garden Theater, London. To Mr. Douglass was extended an invitation to speak, with which he complied, his remarks having special reference to the condition of the colored people in the United States.

A question of importance was being discussed in Scotland whither he now went. The Free Church there received contributions from slaveholders, and, by so doing, gave its sanction to slavery. This system was condemned by many of the leading men of Glasgow. Some undertook to defend in the name of the Bible not only this system but the holding of fellowship with slaveholders. Scotland was roused with excitement over the question. Much good resulted from the agitation which followed. Slavery was thoroughly discussed, and its pernicious practices exposed. To Mr. Douglass more than to any other at the time was given the credit of awakening the moral and religious sentiment of the people against the holding of human beings in bondage. Before his return to America, which soon after followed, some friends raised the money and purchased his freedom from his owner, Captain Auld of Naryland, the amount charged being one hundred and fifty pounds sterling. 


\section{CHAPTER III.}

Editor of the “Nortil Star." - Connection witil John Brown.

ON his return to the United States Mr. Douglass determined to establish a newspaper, his idea being that a newspaper in the hands of a colored man, if properly conducted, would greatly assist in creating public sentiment for the overthrow of slavery. At that time there was no newspaper in this country under the control of colored men, though at intervals efforts had been made to establish one. The name given to the paper which he subsequently published at Rochester, New York, was the North Star, but it was afterwards called Frederick Douglass' Paper. The publication of this journal reached a large circulation and was a source of incalculable benefit to its founder. He was required to write editorials and other matter, and had, therefore, to inform himself upon the subjects about which he wrote. Much time was necessarily spent in reading and research, so that, under the circumstances, his paper was for him the very best educator. In his early anti-slavery life he was a disciple of $\mathrm{Mr}$. Garrison and believed with him in the pro-slavery character of the constitution of the United 
States-that slavery could only be effectually destroyed by dissolving the union. He now held the opposite view, and ably defended his changer opinions through the columns of the North Star.

In June, I 872 , he suffered a severe loss. His house was burned down, and among the other losses he sustained was that of twelve volumes of his paper. These he has been able to replace only in part. The destruction of these volumes is not a loss to the editor alone; it is also a loss to the country, for they contained some of his best thoughts upon many of the most important questions which were before the people from I 848 to I 860 .

Mr. Douglass during one winter delivered a course of lectures on Sunday evening of each week in Corinthian Hall, in Rochester, and these lectures contributed in creating a healthy antislavery sentiment in that city and western New York. In the midst of all these duties he also found time to act as conductor of the Underground railroad. It was his business to receive fugitive slaves, secrete them, raise means, and send them on to Canada.

Soon after he began to publish his paper, he became acquainted with John Brown, then residing in Springfield, Mass. Mr. Douglass on invitation visited that personage, who afterwards became so famous, and thus describes him: "In 
person he was lean, strong, and sinewy; of the best New England mold, built for times of trouble, fitted to grapple with the flintiest hardships. Clad in plain American woolen, shod in boots of cowhicle leather, and wearing a cravat of the same substantial material; under six feet high, less than a hundred and fifty pounds in weight, aged about fifty, he presented a figure straight and symmetrical as a mountain pine. His bearing was singularly impressive. His head was not large, but compact and high. His hair was coarse, strong, slightly gray, and closely trimmed, and grew low on his forehead. His face was smoothly shaved, and revealed a strong, square mouth, supported by a broad and prominent chin. His eyes were bluish gray, and in conversation they were full of light and fire. When on the street, he moved with a long, springing, racehorse step, absorbed in his own reflections, neither seeking nor shunning observation. Such was Captain Brown, whose name has now passed into history as one of the most marked characters and greatest heroes known to American fame."

Mr. Brown explained the plan he had formed of freeing the bondmen of the South. It then was not his purpose to cause an insurrection of the slaves; but he proposed that certain reliable men whom he would select and place at different points in the mountains of Virginia and Mary- 


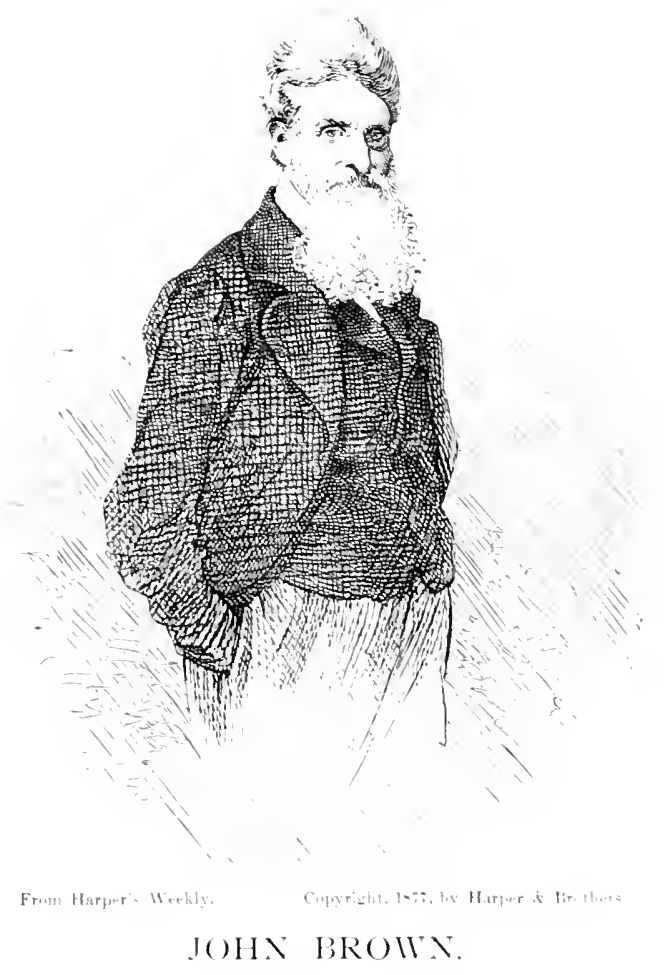



land, should go down into the lowlands, as opporiunity offered, and induce slaves to escape. These should then be sent to Canada through means which would be provided. This in substance was Mr. Brown's plan. Mr. Douglass was very much impressed with his visit to John Brown, and began to doubt that slavery could ever be destroyed by peaceful means. From this time on his speeches showed that this impression had become a firm belief.

Nothing was attempted by Brown in this matter till after the Kansas difficulty was settled. The two men continued friends from their very first acquaintance, and frequently exchanged visits. Just after the Kansas trouble Brown came to Rochester and remained with Mr. Douglass several weeks. While there he prepared a constitution which he intended should govern those associated with him. Mr. Douglass has now a copy of this constitution in Brown's own handwriting. It had been Brown's purpose to begin work in 1858 , but, on account of the exposure of his plans by an Englishman whom he had met in Kansas, operations were postponed a year later.

This year brought some changes in the original plans. Three weeks before he made his raid on Harper's Ferry, he wrote to Mr. Douglass to come to Chambersburg, Penn., as he wished to 
confer with him. The place selected for the meeting was an old stone quarry in the suburbs of the city. Thither Mr. Douglass went, taking with him Shields Green, a fugitive slave from South Carolina whom Brown had met at $\mathrm{Mr}$. Douglass' house in Rochester. What took place in that memorable conference August I9, we will set forth in the exact language of Mr. Douglass as he has himself related it: "When I reached Chambersburg, a good deal of surprise was expressed (for I was instantly recognized), that I should come there unannounced, and I was pressed to make a speech to them, with which invitation I readily complied. Meanwhile, I called upon Mr. Henry Watson, a simple-minded and warm-hearted man, to whom Captain Brown had imparted the secret of my visit, to show me the road to the appointed rendezvous. Watson was very busy in his barber's shop, but he dropped all and put me on the right track. I approached the old quarry very cautiously, for John Brown was generally well armed and regarded strangers with suspicion. He was there under the ban of the government, and heavy rewards were offered for his arrest, for offenses said to have been committed in Kansas. He was passing under the name of John Smith. As I came near, he regarded me rather suspiciously, but soon recognized me, and received me cordially. He had in 
his hand when I met him, a fishing-tackle, with which he had apparently been fishing in a stream hard by; but I saw no fish, and I did not suppose he cared much for his 'fisherman's luck.' The fishing was simply a disguise, and was certainly a good one. He looked every way like a man of the neighborhood, and as much at home as any of the farmers around there. His hat was old, and storm beaten, and his clothing was about the color of the stone quarry itself-his then present hiding place.

"His face wore an anxious expression, and he was much worn by thought and exposure. I felt that I was on a dangerous mission, and I was as little desirous of discovery as himself, though no reward had been offered for me.

"We-Mr. Kagi, Captain Brown, Shields Green, and myself-sat down among the rocks and talked over the enterprise which was about to be undertaken. The taking of Harper's Ferry, of which Captain Brown had merely hinted before, was now declared as his settled purpose, and he wanted to know what I thought of it. I at once opposed the measure with all the arguments at my command. To me, such a measure would be fatal to running off slaves (as was the original plan), and fatal to all engaged in doing so. It would be an attack upon the federal government, and would array the whole country against us. 
Captain Brown did most of the talking on the other side of the question. He did not at all object to rousing the nation; it seemed to him that something startling was just what the nation needecl. He had completely renounced his old plan, and thought that the capture of Harper's Ferry would serve as notice to the slaves that their friends had come, and as a trumpet to rally them to his standard. He described the place as to its means of defense, and how impossible it would be to dislodge him if once in possession. Of course I was no match for him in such matters, but I told him, and these were my words, that all his arguments, and all his descriptions of the place, convinced me that he was going into a perfect steel trap, and that once in he would never get out alive; that he would be surrounded at once and escape would be impossible. He was not to be shaken by anything I could say, but treated my views respectfully, replying that even if surrounded he would find means for cutting his way out; but that would not be forced upon him; he should have a number of the best citizens of the neighborhood as his prisoners at the start, and that holding them as hostages, he should be able if worse came to worse, to dictate terms of cogress from the town. I looked at him with some astonishment that he could rest upon a reed so weak and broken, and told him that Vir- 
ginia would blow him and his hostages sky-high, rather than that he should hold Harper's Ferry an hour. Our talk was long and earnest; we spent the most of Saturday and a part of Sunday in this debate-Brown for Harper's Ferry, and I against it; he for striking a blow which should instantly rouse the country, and I for the policy of gradually and unaccountably drawing off slaves to the mountains, as at first suggested and proposed by him. When I found that he had fully made up his mind and could not be dissuaded, I tumed to Shields Green and told him he heard what Captain Brown had said; his old plan was changed, and that I should return home, and if he wished to go with me he could do so. Captain Brown urged us both to go with him, but I could not do so, and could but feel that he was about to rivet the fetters more firmly than ever on the limbs of the enslaved. In parting lie put his arms around me in a manner more than friendly, and said: 'Come with me, Douglass, I will defend you with my life. I want you for a special purpose. When I strike, the bees will begin to swarm, and I shall want you to help hive them.' But my discretion or my cowardice made me proof against the dear old man's eloquenceperhaps it was something of both which determined my course. When about to leare I asked Green what he had decided to do, and was sur- 
prised by his coolly saying in his broken way, 'I b'leve I'll go wid de ole man.' Here we separated; they to go to Harper's Ferry, and I to Rochester."

On their way to Chambersburg Mr. Douglass and Shields Green stopped at Mrs. E. A. Gloucester's in Brooklyn, August I 8, who sent through Mr. Douglass to Captain Brown a letter and a small amount of money. The following is a copy of a letter signed by colored citizens of Philadelphia, which was found among the papers at the Kennedy farm, Brown's headquarters before moving on to Harper's Ferry, and was sent to Mr. Douglass at Rochester in September: "F. D., Esq., Dear Sir,-The undersigned feel it to be of the utmost importance that our class be properly represented in a convention to come off right away (near) Chambersburg, in this state. We think you are the man of all others to represent us; and we severally pledge ourselves that in case you will come right on we will see your family well provided for during your absence, or until your safe return to them. Answer to us and to John Henrie, Esq., Chambersburg, Penn., at once. We are ready to make you a remittance, if you go. We have now quite a number of good but not very intelligent representatives collected. Some of our numbers are ready to go on with you." It was never known why this letter 
was sent to Mr. Douglass. He thinks, however, that the sending of it was prompted by Kagi, who was present at the Chambersburg interview, and had heard him say that he could not go to Harper's Ferry in the way proposed. Kagi probably thought a letter signed as this was would induce $\mathrm{Mr}$. Douglass to reconsider his determination and at last consent to accompany Brown.

The report of the capture of Harper's Ferry was received by $\mathrm{Mr}$. Douglass in Philadelphia. Information soon followed to the effect that Brown had been captured, and that a carpet bag had been found containing letters from abolitionists, among which were some from Mr. Douglass. Leaving the city upon the advice of friends, Mr. Douglass went to New York. There he learned that the government intended to arrest all who had been in any way connected with the raid at Harper's Ferry. Alarmed at this intelligence he sent a message to his son Lewis at home to secure the important papers which were in his "high desk." Arriving at Rochester, he ascertained through Lieutenant Governor Selden, his neighbor, that the governor of New York would surrender him upon legal demand by the gorernor of Virginia. Mr. Selden advised him to leave the country without delay. Canada being the nearest refuge, he went thither. Governor Wise, hearing that he had gone to Michigan, 
made a demand upon the governor of that state for his detention and surrender to the Virginia authorities. The following letter, which was sent to Mr. Douglass by the historian, B. J. Lossing, after the war, shows that he acted wisely at the time in taking the advice of friends and thus putting himself beyond the danger of apprehension :-

\section{(Confidential.)}

To His Excellency, James Buchanan, President of the United States, and to the Honorable Postmaster-General of the United States :--

Gentlemen,--I have information such as has caused me, upon proper affidavit, to make requisition upon the executive of Michigan for the delivery up of the person of Frederick Douglass, a negro man, supposed now to be in Michigan, charged with murder, robbery, and inciting servile insurrection in the state of Virginia. My agents for the arrest and reclamation of the person so charged are Benjamin M. Morris and William N. Kelly. The latter has the requisition, and will wait on you to the end of obtaining nominal authority as post office agent. They need be very secretive in this matter, and some pretext for traveling through the dangerous section for the execution of the law in this behalf, and some protection against obtrusive, unruly, or lawless violence. If it be proper so to do, will the postmaster-general be pleased to give to Mr. Kelly, for each of these men, a permit and authority to act as detectives for the post office department, without pay, but to pass and repass without question, delay, or hindrance?

Respectfully submitted by

Your obedient servant,

HenRY A. Wise.

It was evident that Mr. Douglass could not hope for a fair trial before a Virginia jury. He 
also doubtless felt that even in Canada he was not safe, for there was danger of being kidnaped and brought back to the United States; hence he left for England on the i 2 th of the same month. He remained abroad six months, speaking upon anti-slavery and other subjects in England and Scotland, at the end of which time he was summoned home by the death of his daughter Annie.

Some were disposed to criticise Mr. Douglass for the course he pursued in the Harper's Ferry affair, and went so far as to assert that he deserted Brown on that occasion. It is no doubt true that these criticisms grew out of the reports telegraphed over the country, after the capture of Brown, in which Cook, one of Brown's men, was made to say that Mr. Douglass had promised to be present in person on this famous expedition. Mr. Douglass, before taking his departure for Europe, wrote a letter which was published in the Rochester Democrat and American, in which he emphatically denied these statements, thus attributed to Cook. The one sentence I quote is characteristic of the whole letter: "I therefore declare that there is no man living and no man dead who, if living, could truthfully say that I ever promised him or anybody else, either conditionally or otherwise, that I would be present in person at the Harper's Ferry insurrection." Mr. 
Douglass, in this letter quoted from, also promised at the proper time, when it could be done without compromising the friends of the slaves, to tell all he knew of the attempt of John Brown to liberate the bondmen of Virginia and Maryland. As the country knows, he has faithfully kept that promise in a published statement giving all the facts as far as he knew them. Subsequent history also verifies what he wrote to the Rochester Democrat and American while in Canada. The recent publication of the Life and Letters of John Brown, by his friend, F. B. Sanborn, in which all the particulars of the foray at Harper's Ferry are given to the public, coincides with what Mr. Douglass has said. I quote Mr. Sanborn, page 4I8:-

"John Brown's long meditated plan of action in Virginia was wholly his own, as he more than once declared, and it was not until he had long formed and matured it, that he made it known to the few friends outside of his own household who shared his confidence in that matter. I cannot say how numerous these were, but beyond his family and the armed followers who accompanied him, I have never supposed that his Virginia plan was known to fifty persons. Even to those few it was not fully communicated, though they knew that he meant to fortify himself somewhere in the mountains of Virginia or Tennessee, and 
from that fastness, with his band of soldiers, sally out and emancipate slaves, seize hostages, and levy contributions on the slaveholders. Moreover, from the time he first matured it, there were several changes, amounting at last to an entire modification of the scheme. As he declared it to me in 1858 in the house of Gerrit Smith at Peterboro, it was very different from the plan he had unfolded to Thomas and to that other Maryland freedman, Frederick Douglass, at Brown's own house in Springfield in I $847 . "$

I believe there is no one who, in the light of developments, will say that Mr. Douglass acted in bad faith to John Brown. The interview at Chambersburg shows that Brown never lost confidence in his friend. Mr. Douglass never saw Cook, had no communication with him whatever. Even if Cook did say what was imputed to him, it can be shown by Brown himself that he was not always truthful. Brown, on his way to the scaffold, said to Cook, who had made a confession, "You have made false statements-that I sent you to Harper's Ferry; you know I protested against your coming."

The following statement, which recently appeared in a leading journal, will throw additional light upon the facts connected with the hurricd departure of Mr. Douglass for Canada just after John Brown was taken at Harper's Ferry. 
" "Yes, sir; I am the man who saved Fred. Douglass' life when "Old John Brown " was captured at Harper's Ferry. I suppressed a dispatch addressed to the sheriff of Philadelphia, instructing him to arrest Douglass, who was then in that city, as proofs of his complicity in the memorable raid were discovered when John Brown was taken into custody.'

"Seated on the doorstep of his cozy cottage, a few miles outside of Vineland, New Jersey, was John W. Hurn, a pleasant, gray-bearded man of sixty, who, when questioned, answered as above respecting the aid rendered by him to the noted abolitionist.

" 'At that time I was a telegraph operator located in Philadelphia,' continued Mr. Hurn, ' and when I received the dispatch I was frightened nearly out of my wits. As I was an ardent admirer of the great ex-slave, I resolved to warn Douglass of his impending fate, no matter what the result might be to me. The news had just been spread throughout the country of the bold action of John Brown in taking Harper's Ferry. Everybody was excited and public feeling ran high. Before the intelligence came that Brown had been captured, the dispatch I have mentioned was sent by the sheriff of Franklin county, Penn., to the sheriff of Philadelphia, informing him that Douglass had been one of the 
leading conspirators, and requesting that he should be immediately apprehended.

" 'Though I knew it was illegal to do so, I quietly put the dispatch in my pocket, and, asking another operator to take my place, started on my search for Fred. Douglass. I went directly to Miller McKim, the secretary of the contraband, underground, fugitive railway office in Philadelphia, and inquired for my man. Mr. McKim hesitated to tell me, whereupon I'showed him the dispatch and promised him not to allow it to be delivered within three hours. I told him I would not do this unless he agreed to get Mr. Douglass out of the states. This he readily assented to, for it was his business to spirit escaped slaves beyond the reach of the authorities. I returned to the telegraph office and kept a sharp lookout for similar dispatches. None arrived, however, and when the allotted time expired I sent the belated message to its destination.

" In the mean time those intrusted with my secret saw Mr. Douglass and urged him to leave the town as quickly as possible. He was loath to do so at first, but the expostulation of his friends overcame his objections, and in an hour he left on a railroad train. He reached his home in Rochester, New York, in safety, destroying the compromising documents, and then packed his 
gripsack and started for Canada. It was fortunate for him that he left so soon as he did, for immediately after his departure from Rochester his home was surrounded by officers.' "

We take the liberty of quoting in this connection for the information of the reader an incident which occurred in the early acquaintance of $\mathrm{Mr}$. Douglass with Brown, related by a writer who styles himself the "Rambler," in an article published in a New England paper.

"In the spring of ' 57 , just after the Dred Scott decision of the Supreme Court, the Rambler (being then a resident of Worcester, Mass., fondly called by the citizens 'The Heart of the Commonwealth ') was getting up a lecture for Frederick Douglass. He secured the then mayor of the city to preside, it being the first time that the mayor of an American city had presided at an address of Mr. Douglass. The Rambler called at the house of Hon. Eli Thayer, then member of Congress from the ninth district, to ask him to sit on the platform. Here he found a stranger, a man of tall, gaunt form, with a face smooth shaven, destitute of the full beard that later became a part of history. The children were climbing over his knees; he said, 'The children always come to me.' 'The Rambler was introduced to John Brown of Ossawatomie. How little one imagined then that, within less than three years, 
the name of this plain, homespun man would fill America and Europe.

"Mr. Brown kindly consented to occupy a place on the platform, and at the urgent request of the audience spoke briefly. It is one of the curious facts, that many men who can do it are utterly unable to tell about it. John Brown, a flame of fire in action, was dull in speech. How many men are a living flame on the platform, who are nowhere in action. John Brown taught the world one lesson among others. If a man fully, absolutely, believes what he says, and if he has laid aside all fear, so that death has no terrors for him, that man is a power, that man is to be feared." 


\section{CHAPTER IV.}

Second Visit to England.-Tile War of tile REBELLion.

Mr. Douglass returned from England in time to take part in the great presidential campaign of 1860. He entered into that contest with earnestness and enthusiasm, for he believed that it was a struggle which would decide the fate of slavery in the United States. Later on when the war had been in progress three years, and the government decided to accept colored volunteers, he became conspicuous for the support and encouragement he gave in the enlistment of colored troops. When Governor Andrew of Massachusetts was given authority by President Lincoln to put into the field two colored regiments, the 54th and

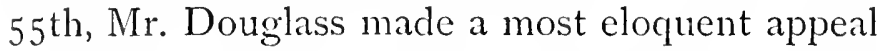
through his paper to the colored people of the North to enlist. There being few colored men in Massachusetts, it was found necessary to go outside of that state to recruit. Mr. Douglass not only urged and induced others to go, but gave his two sons, Lewis and Charles, to the cause; the latter of whom was the first colored man to enlist in the state of New York. Some time later his third and last son, Frederick, Jr., also entered the service. 



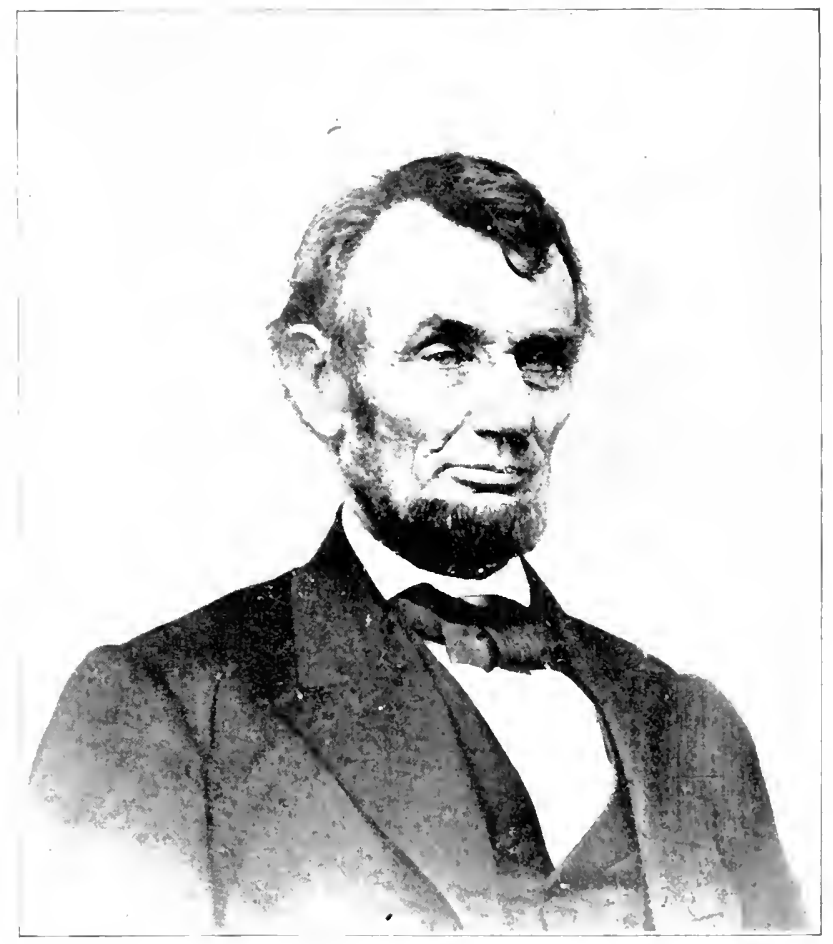

ABRAHAM LINCOLN. 
It was proposed in Pennsylvania to raise ten reginents, and Mr. Douglass was again requested to give his assistance in the work of recruiting. He entered this service with the understanding that when they enlisted colored men should receive the same treatment that was accorded to white soldiers. The government, however, did not do in this respect what was expected of it; on which account Mr. Douglass, thoroughly disheartened, suspended his labors for a time. But finally, urged by Mr. Stearns, who had first sought his assistance in enlisting men, he went to Washington and presented the matter to the president and secretary of war. He thus describes his first meeting with President Lincoln: "I shall never forget my first interview with this great man. I was accompanied to the executive mansion and introduced to President Lincoln by Senator Pomeroy. The room in which he received visitors was the one now used by the president's secretaries. I entered it with a moderate estimate of my own consequence, and yet there I was to talk with, and even to advise, the head of a great nation. Happily for me there was no vain pomp and ceremony about him. I was never more quickly or more completely put at ease in the presence of a great man than in that of Abraham Lincoln. He was seated, when I entered, in a low arm-chair, with his feet extended on the 
floor, surrounded by a large number of documents and several busy secretaries. The room bore the marks of business, and the persons in it, the president included, appeared to be much overworked and tired. Long lines of care were already deeply written on Mr. Lincoln's brow, and his strong face, full of earnestness, lighted up as soon as my name was mentioned. As I approached and was introduced to him, he rose and extended his hand, and bade me welcome. I at once felt myself in the presence of an honest man-one whom I could love, honor, and trust without reserve or doubt. Proceeding to tell him who I was, and what I was doing, he promptly but kindly stopped me, saying, 'I know who you are, Mr. Douglass. Mr. Seward has told me all about you. Sit down; I am glad to see you.' I then told him the object of my visit; that I was assisting to raise colored troops; that several months before I had been very successful in getting men to enlist, but that now it was not easy to induce the colored men to enter the service, because there was a feeling among them that the government did not deal fairly with them in several respects. Mr. Lincoln asked me to state particulars. I replied that there were three particulars which I wished to bring to his attention. First, that colored soldiers ought to receive the same wages as those paid to white soldiers. Sec- 
ond, that colored soldiers ought to receive the same protection when taken prisoners, and be exchanged as readily, and on the same terms, as other prisoners, and if Jefferson Davis should shoot or hang colored soldiers in cold blood, the United States government should retaliate in kind and degree without delay upon Confederate prisoners in its hands. Third, when colored soldiers, seeking the 'bauble reputation at the cannon's mouth,' performed great and uncommon service on the battlefield, they should be rewarded by distinction and promotion precisely as white soldiers are rewarded for like services."

$\mathrm{Mr}$. Lincoln was impressed with the argument of Mr. Douglass, and in his reply spoke encouragingly of the intentions of the administration. After this interview with the president, and a subsequent one with Secretary Stanton, Mr. Douglass felt encouraged and went away feeling assured that the government would, as fast as conditions warranted, deal justly by the colored soldier.

He was one of the crowd that listened to the second inauguration address of President Lincoln. In the evening of the same day he attended the president's reception. No colored person had hitherto presented himself on such an occasion. When conducted to the president's room, Mr. Lincoln received him with marks of great respect and attention. 


\section{CHAPTER V.}

Continued Literary Efrorts. - Freedmen's Bank.-Orficial Career in Washington.Visit to his Old Maryland Home.

After the war closed and the country had returned to pursuits of peace, Mr. Douglass began to think of what calling he should follow. His great life work, the abolition of slavery, had been accomplished, and it seemed that now there was little for him to do. He had about made up his mind to spend the remainder of his days in farming, when invitations came to him to deliver lectures before colleges and literary societies. Thus a new vocation was opened to him, by which he might improve his knowledge and better his pecuniary condition. While employed by the Anti-Slavery Society he had been paid a salary of $\$ 450$ a year, now he was offered \$IOO and often \$200 for one lecture.

Mr. Douglass early saw that the greatest protection of the colored man after emancipation would be the ballot-in fact, it would prove his only safety; he, therefore, was among the very first to begin the agitation of the question, suffrage for the negro. This question was discussed in the National Loyalists' Convention, which was 


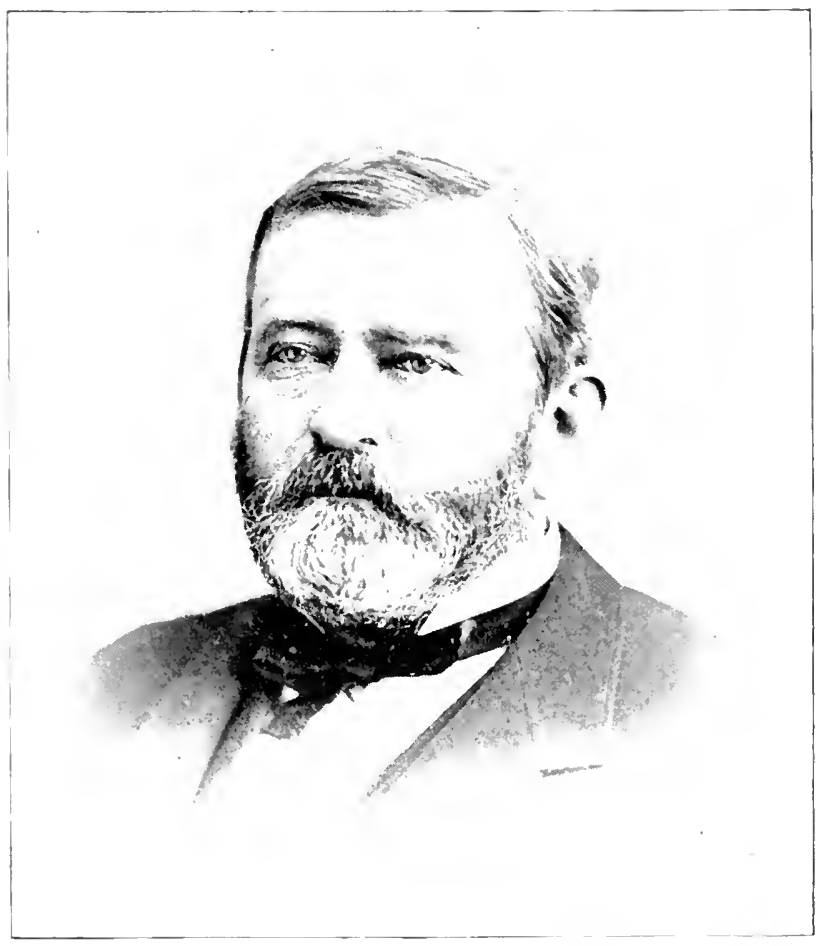

I. S. GRANT. 

held in Philadelphia in I S66. Mr. Douglass, as a delegate from Rochester, attended this gathering and made an earnest speech, urging a free and untrammeled ballot to all citizens of the country. The convention, though divided at first in opinion, before it adjourned passed resolutions favoring the enfranchisement of the freedman. The question grew rapidly in public favor. President Grant recommended the measure to Congress, and erelong the ballot was made secure to the negro by the adoption of the i 5 th amendment to the constitution.

In the year 1869 , having been induced by some friends, Mr. Douglass came to Washington and established the New National Era newspaper. This paper was finally turned over to his sons, Lewis and Frederick.

About this time he was elected president of the Freedmen's Bank, an institution intended as a secure depository for the savings of the colored people. The intentions of the founders of this organization were no doubt good, but by bad management the bank was brought to ruin. Mr. Douglass had previously been elected a trustee of this corporation, while residing in Rochester, and had attended a few of its meetings, but he knew nothing personally of its true condition. He himself says: "About four months before this splendid institution was compelled to close its 
doors in the starved and deluded faces of its depositors, and while I was assured by its president and by its secretary of its sound condition, I was solicited by some of its trustees to allow them to use my name in the board as a candidate for its presidency. So I waked up one morning to find myself seated in a comfortable arm-chair, with gold spectacles on my nose, and to hear myself addressed as President of the Freedmen's Bank. I could not help reflecting on the contrast between Frederick the slave boy, running about at Colonel Lloyd's with only a tow linen shirt to cover him, and Frederick, president of a bank, counting its assets by millions. I had heard of golden dreams, but such dreams had no comparison with this reality. And yet this seeming reality was scarcely more substantial than a dream. My term of service on this golden height covered only the brief space of three months." Mr. Douglass, when he found out by careful investigation the facts in reference to the condition of the bank, to use his own words, when he discovered that he was "married to a corpse," he immediately went before the Senate Finance Committee, of which Hon. John Sherman was chairman, and gave it as his opinion that the bank was insolvent and could not recover from its losses. The committee took the same view and immediately three commissioners were ap- 
pointed by Congress to wind up the affairs of the company.

Mr. Douglass was sent by President Grant with Messrs. Wade, Howe, and White, commissioners to Hayti. He took the position with General Grant in favor of annexation of that country to the United States. Mr. Sumner championed the opposite view in the Senate and held that annexation meant the extinction of the Haytian people as such. Mr. Douglass held that a union would give protection to the weaker state and prosperity beyond what it could ever enjoy as a separate government. On this question the opinion of the country was divided. There were strong arguments used for and against the scheme.

In the year i 872 General Grant was nominated a second time for the presidency. The independent republicans, dissatisfied with his administration, nominated Horace Greeley. In the national convention of colored men held in New Orleans in the same year, over which Mr. Douglass presided, an effort was made to get that body to indorse the independent candidate. Mr. Douglass used his influence to prevent such action, and had he not been present it is probable that the convention would have passed resolutions indorsing Mr. Greeley for the presidency. Having been chosen an elector at large of the state of New York on the Republican ticket, he was 
commissioned by the electoral college of the state to carry the vote to the capitol at Washington.

Mr. Douglass had been appointed by President Grant in his first term a member of the council of the District of Columbia, but was compelled, by the pressure of other duties, to resign after a short time, and his son Lewis was appointed to the position. When Mr. Hayes became president, he appointed Mr. Douglass marshal of the district. Immediately a great cry was made against this act of the president, and representatives of the bar appeared before the Senate committee for the purpose of defeating his confirmation. Mr. Conkling, then a member of the Senate, in executive session, made an able speech in support of Mr. Douglass. Other members came to his aid, and the Senate promptly confirmed the appointment. One of the objections made to Mr. Douglass holding the office of marshal was that he would be required to introduce guests to the president on state occasions. But this duty did not by law devolve upon that officer. The president could as well designate any other officer at the capital to perform such service. Mr. Douglass did, however, introduce to President Hayes during his term of office many distinguished persons, and he on such occasions was always treated with the greatest courtesy by this 


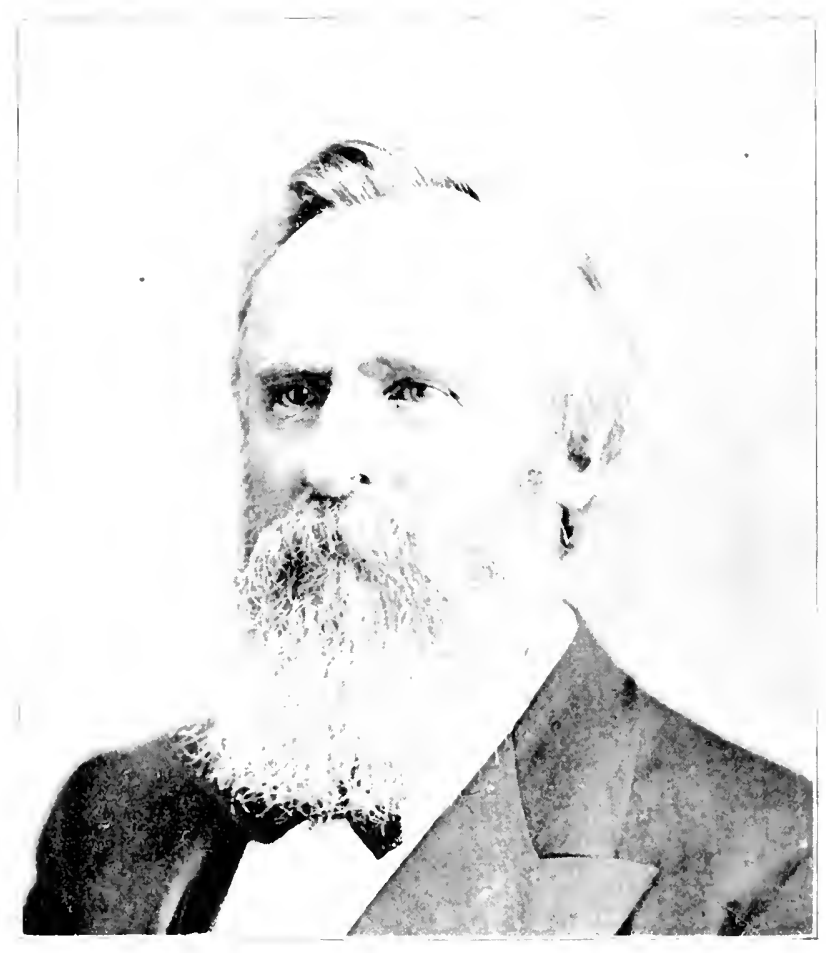

R【THERF(RI) H, HALS. 

chief magistrate. Great credit should be given Mr. Hayes for the courage he displayed in appointing Mr. Douglass in opposition to the wishes of the pro-slavery sentiment of the District, and that he could not be induced to revoke the appointment.

It had long been the cherished desire of $\mathrm{Mr}$. Douglass to visit his old Maryland home. During slavery times he did not think it safe to gratify his wishes in this respect. The opportunity to do so, however, presented itself while he was holding this office. He went first to St. Michael's upon the invitation of Mr. Charles Caldwell, a colored man. Arriving there he was invited by his old master, Captain Auld, now eighty years of age, to visit him, he at this time being on his deathbed. When Mr. Douglass entered the room in which the sick man lay, the captain addressed him as Marshal Douglass and treated him with great respect. The interview was a most affecting one, but lasted only a few minutes, owing to the weak condition of the agcd veteran. Mr. Douglass while in this neighborhood also visited the Eastern jail, where in youth he had been confined with other slaves for attempting to run away from their masters.

He some time after paid a visit to the Lloyd plantation in Talbot county, which he left when he was only eight yenss old, in 1825. He there 
met with the kindest reception from the Lloyds, who were still living on the premises. He was entertained in the old family mansion; was escorted over the grounds, saw the buildings, many of them standing just as he was accustomed to see them in former times. He conversed with many of the colored people who were children when he was a boy, and whom he then knew; looked into the kitchen where he had last seen his mother, and his eyes grew dim with tears. He visited the family burying-ground, and while there Mr. Howard Lloyd kindly presented him a bouquet of flowers, taken from the graves of those he had known in his childhood days.

Mr. Douglass, on Decoration day, May 30, I8S I, was invited to deliver his lecture on John Brown at Storer College, an institution established in the interest of the colored race at Harper's Ferry, West Virginia. On the platform sat Andrew J. Hunter, who was the prosecuting attorney when the old hero was convicted. He applauded parts of the lecturer's remarks heartily. Truly the times had changed, and the sentiments and feelings of that community had changed with them.

When Mr. Garfield, in I 88 I, became president, Mr. Douglass was appointed recorder of deeds of the District of Columbia, which position he held till the appointment of Mr. James C. Matthews, in the spring of 1886 . 


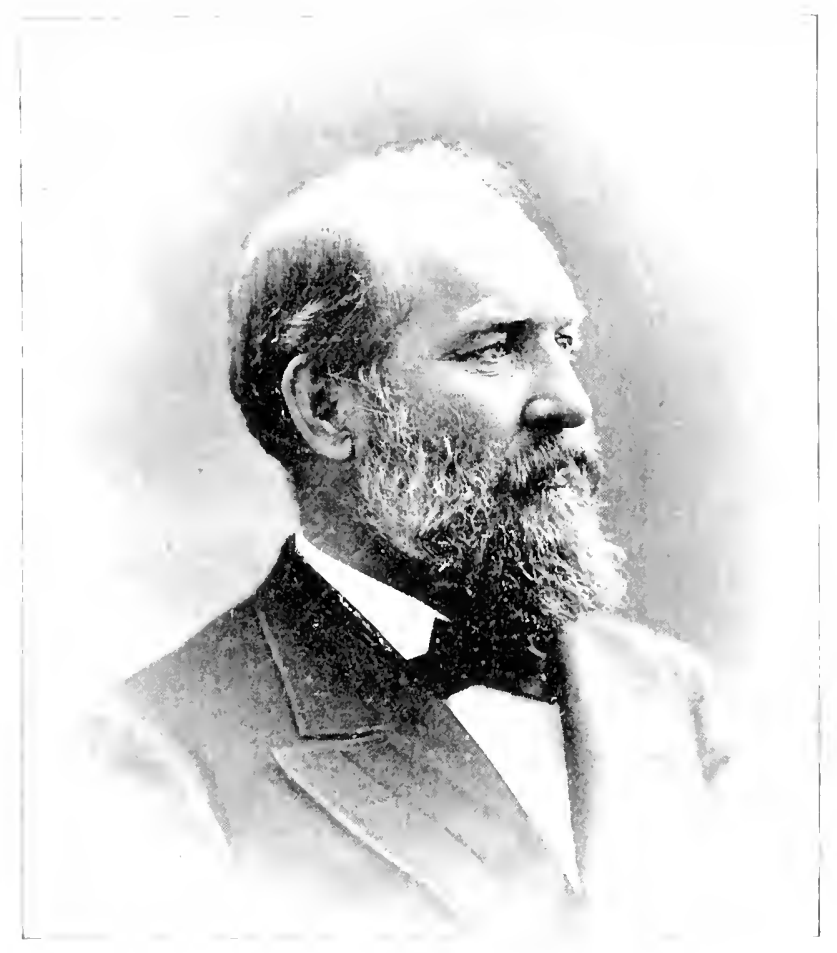

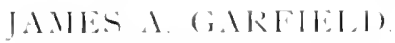





\section{CHAPTER VI.}

Banguet in Recognition of his Public Slervices.-The Douglass in his HaLl.

ON the first of January, ${ } s_{3}$, the twentieth anniversary of the Emancipation Proclamation, a banquet was tendered Hon. Firederick Douglass, in recognition of his high personal attainments, and of his eminent public services in behalf of his race and humanity, at Freund's, Washington, D. C. The entertainment was not only a social event of unusual interest, but one worthy of the occasion. No more brilliant array of talent has ever assembled to do honor to a great man of our race. The tables were beautifully decorated, and laden with the choicest viands. They were so arranged as to group the company about the distinguished guest, who sat at the head of the central table. There were present doctors of divinity, bishops, lawyers, doctors of medicine, members of Congress and northern state legislatures, professors of colleges, authors, and editors of newspapers.

After prayer by Bishop John M. Brown, the company spent two hours in partaking of the excellent dinner placed before them. It was ten o'clock when ex-Senator Bruce introduced Mr. 
Douglass in an appropriate and eulogistic address, closing with these words: "I now, gentlemen, have the honor to present to you Frederick Douglass, the distinguished guest of this happy occasion, whose fame as an orator and an earnest and effective worker in the cause of human liberty is not confined to one continent, but known throughout the civilized world, and whose name is a household word, cherished and loved by millions who, from writhing under the cruel chains of slavery, have at last been brought into the bright sunlight of freedom. He will now respond to the toast, 'The Day,' this, the twentieth anniversary of the one fixed by the sainted Lincoln, when the Emancipation Proclamation should go into full force and effect."

In responding to the sentiment $\mathrm{Mr}$. Douglass said :-

"Mr. President and gentlemen, since you have taken me into your confidence, my life, as most of you know, was begun under a great shadow. Before I was made part of this breathing world the chains were forged for my limbs, and the whip of a slave master was plaited for my back, and while I have labored and suffered in the cause of justice and liberty, I have no doleful words to utter here to-night. It was said of a great Irish orator, speaking of Irish liberty, that he harl rocked it in its cradle and had followed it to its 
grave. I can say of the colored man's liberty, I have rocked it in its cradle and witnessed its manhood, for I stand to-night in the presence of emancipated millions. He would be a gloomy man indeed who could live to see the desire of his soul accomplished, and yet spend his life in grief. I am happy to say now and here that while my life has been more of cloud than sunshine, more of storm than calm, it has nevertheless been a cheerful life, with many compensations on every hand, and not the least among those compensations, I reckon the good word and will which have come to me on the present occasion. This high festival of ours is coupled with a day which we do well to hold in sacred and everlasting honor, a day memorable alike in the history of the nation and in the life of an emancipated people. This is the twentieth anniversary of the proclamation of emancipation by Abraham Lincoln-a proclamation which made the name of its author immortal and glorious throughout the civilized world. That great act of his marked an epoch in the life of the whole American nation. Reflection upon it opens to us a vast wilderness of thought and feeling. Man is said to be an animal looking before and after. To him alone is given the prophetic vision, enabling him to cliscern the outline of his future through the mists and shadows of the past. The day we celebrate 
affords us an eminence from which we may in a measure survey both the past and the future. It is one of those days which may well count for a thousand years.

"Until this day twenty years ago there was a vast incubus on the breast of the American people, which baffled all the wisdom of American statesmanship. Slavery, the sum of all villainies, like a vulture, was gnawing at the republic. Until this day there stretched away behind us an awful chasm of darkness and despair of more than two centuries. Until this day the American slave, bound in chains, tossed his fettered hands on high and groaned for freedom's gift in vain. Until this day the colored people of the United States lived in the shadow of death, hell, and the grave, and had no visible future.

“. Agonized heart throbs convulsed them while sleeping,

And the wind whispered death, while over them sweeping.'"

"Until this day we knew not when or how the war for the union would end; until this day it was doubtful whether liberty and union would triumph, or slavery and barbarism. Until this day victory had largely followed the arms of the Confederate army. Until this day the mighty conflict between the North and South appeared to the eye of the civilized world, as destitute of moral qualities. Until this day the sympathies of the world were largely in favor of the Southern 
rebellion. Until this day the man of sable hue had no country and no glory. Until this day he was not permitted to lift a sword, to carry a gun, or wear the United States uniform. Until this day the armies of the republic fought the rebels in fetters, for they fought for slavery as well as for the union. Until this day we presented the spectacle of that weakness, indecision, and blindness which builds up with one hand while it tears down with the other. Until this day we fought the rebels with only one hand, while we chained and pinioned the other behind us. On this day, twenty years ago, thanks to Abraham Lincoln and the great statesmen by whom he was supported, this spell of blasted hopes and despair, this spell of inconsistency and weakness, was broken, and our government became consistent, logical, and strong, for from this hour slavery was doomed, liberty made certain, and the union established.

"We do well to commemorate this day. It was the first gray streak of morning after a long and troubled night of all abounding horrors.

"The future as well as the past claims consideration on this day. Freedom has brought duties, responsibilities, and created expectations which must be fulfilled. There is no disguising the fact that the price of liberty is eternal vigilance, and, if we maintain our high estate in this repub- 
lic, we must be something more than driftwood in a stream. We must keep pace with the nation in all that goes to make a nation great, glorious, and free. Natural equality we have long pleaded, and righteously, but now that the fetters are off, we must be able to plead practical equality, equality of industry, equality of morality, equality of education, equality of wealth, equality of general attainments. I hardly need say here that to all this there are formidable obstacles and discouragements; that we have entered the race of civilization at an immense disadvantage is manifest to the candid judgment of all men. No people ever entered the portals of freedom under circumstances more unpropitious than the American freedmen. They were flung overboard on an unknown sea in the midst of a storm, without planks, ropes, oars, or life preservers, and told they must swim or perish. They were without money, without friends, without shelter, and without bread. The land which they had watered with their tears, enriched with their blood, tilled with their hard hands, was owned by their enemies. They were told to leave their old quarters and seek food and shelter elsewhere. In view of this condition of things the marvel is not so much that they have made little progress, but that they are not exterminated. I regret to observe that even colored men are heard to deny that any 
improvement has taken place in their condition during the last twenty years. How they can do this I am utterly unable to see. Twenty years ago there was perhaps not a single schoolhouse for colored children in the Southern states. Now there are two hundred thousand colored children regularly attending school in those states.

"That fact, which cloes not stand alone, is sufficient to refute all the gloomy stories of croakers as to the progress of the colored freedmen of the South. The trouble with these croakers is that they do not consider the point of the freedmen's departure. They know the heights which they have still to reach, but do not measure the depths from which they have come.

"Twenty years, though a long time in the life of an individual, is but a moment in the life of a nation, and no final judgment can be predicated of facts transpiring within that limited period.

"For one, I can say in conclusion that nothing has occurred within these twenty years which has dimmed my hopes or caused me to doubt that the emancipated people of this country will avail themselves of their opportunities; and by enterprise, industry, invention, discovery, and manly character vindicate the conficlence of their friends, and put to silence and to shame the gloomy predictions of all their enemies."

At the conclusion of the remarks of Mr. Doug- 
lass rapturous applause followed, many of the guests rising from their seats and coming forward to congratulate the venerable orator. After a few minutes the speaking continued. The following gentlemen, in short speeches, responded to sentiments: Hon. John R. Lynch of Mississippi, Colored Men in the South; Hon. John P. Green of the Ohio legislature, The Colored Man as a Legislator; Rev. B. T. Tanner, D.D., The Negro Press; Hon. George W. Williams, The Negro Author; T. Thomas Fortune of the New York Globe, Independent Journalism; Prof. R. T. Greener, The Negro's Adherence to the Republican Party; Hon. Robert Smalls of South Carolina, The Exodus from the South; Prof. J. M. Gregory, The Color Line; Bishop John M. Brown, The A. M. E. Church; William E. Matthews, The Orator and Orators; Dr. John R. Francis, The Profession of Medicine; Jesse Lawson, Our Presiding Officer; J. B. Devaux, The Ladies; E. M. Hewlett, Life Insurance, its Necessity; G. W. Cook, Howard University; Judge Samuel Lee of South Carolina, Co-operation; J. H. Green of Mississippi, The Slater Fund; R. J. Smith, Disunion, Consequent Weakness; W. H. Richards, The Profession of the Law; Joseph Brooks, William Lloyd Garrison; Dr. E. W. Blyden, The Republic of Liberia. At one time while the speaking was in progress 
Mr. Douglass became so impressed with what was said that he rose of his own accord and delivered one of his old time speeches, full of fiery eloquence, in which he contrasted his past life with that of the young men before him, and concluded his impromptu remarks with an earnest appeal to the youth to make the most of their opportunities, show themselves worthy of the great privileges they enjoy and equal to the demands of the age. As soon as Mr. Douglass had resumed his seat Professor R. T. Greener proposed three cheers for the "Old Man Eloquent," which were given with a hearty good will.

Before the company separated, Dr. B. T. Tanner of the Christian Recorder approached Mr. Charles R. Douglass, son of the guest of the evening, and, in the hearing of the writer, made this remark which we think will prove of prophetic import: "From the fact that this company is made up chiefly of young men, we may conclude that the future of your venerable father is secure. He who can command the fealty of the men of his own generation is only secure in his reputation while they survive; but he who has the strength or fitness to command the fealty of the generation coming immediately after him, may count the future as secure."

Thus the entertainment was agreeably prolonged by speaking and conversation, till the late- 
ness of the hour brought the proceedings to a close, and the guests retired feeling that they had spent a pleasant and profitable evening. 


\section{CHAPTER VII.}

Visit Abroad.-Return Home and Reception. -Minister Resident and Consul GenERAL TO HAYTI.

For some time prior to his retirement from public office, Mr. Douglass had contemplated a trip to Great Britain and other countries of the old world. He desired to know more of their people, their government, and institutions. Being released from the cares and responsibilities imposed by official life, he gladly welcomed the opportunity to revisit the scenes of his first two journeys abroad, and to extend his travels to classic Athens, historic Rome, Paris, the most elegant city of the world, free Switzerland, the home of the legendary hero, William Tell, Germany, the country of scholars, and Egypt, the land of pyramids and hieroglyphics. Having made all preparations for the voyage, he and Mrs. Douglass, in September, i886, left New York for Liverpool on the steamer City of Rome.

He returned to the United States after a year's absence, and on his arrival in Washington was tendered a public reception by his fellow citizens in the Metropolitan African Methodist Episcopal Church of that city, one of the largest and most 
handsome edifices owned by colored people in the country. The church, beautifully and tastefully decorated with flags and bunting, was illuminated with lights of various colors. Rev. Dr. T. G. Stewart presided. After music by the choir of the church, Rev. Walter Brooks recited the following original poem:-

\section{ODE OF WELCOME.}

Honor the statesman now returning From the shores of France and Spain, From the British Isles and mainland, To his native home again.

Honor the man whose potent speeches In the world both old and new, Now for him a fame undying Made the bondman friends most true.

Honor the old man in his glory, Read the story of lis life, Tell it to your sons and daughters Till they feel the bitter strife.

Strife for freedom, land, and manhood, Strife for all the rights of men, Hold him up the friend of letters, In his threescore years and ten.

Hold him up a people's leader, In the struggle which we wage 'Gainst oppression dark and cruel, Honor him, the prince and sage.

Honor him, and hail him welcome, Welcome Frederick Douglass here, Where he made long fight for freedom, Wielding tongue of fire e'er. 
Honor him with shouts of gladness, Bid the nation honor, too, For in him the cause of justice Finds a champion strong and true.

Champion of the rights of all men, What their color, what their clime, Does not matter-he is loyal, Honor him, the Old Sublime!

Honor to him and praise Jehovah, Who from bondage called him out, To deliver from their thraldom Christ's own people, true, devout.

Honor him, though seeing never, Angels sent to break his cliains, Bidding him to flee his serfdom, And command a living name.

Angels sent to guide his footsteps And to clothe his tongue with speech, Touch his heart with fire from heaven, While he freedom bravely preach.

Honor him, God's chosen proplet, Sent against his people vile, Who for sordid gain in barter, Did themselves with blood defile.

Blood of their own brothers bleeding, Bleeding under chain and lasl, As they toiled and prayed and waited, Freedom's coming, slavery's crash.

Honor him, the people's hero. Praying God might make it plain That the blow he struck for freedom Was God's wrath unloosed again. 
Wrath that burned like fire consuming, Till this nation rent in twain, On the issue denouncing bondage, With its blood washed out the stain.

Mr. Brooks having concluded his poem, which throughout the recital pleased and entertained the audience, Professor W. S. Montgomery, in scholarly language, made the opening address, and then Rev. C. W. Handy welcomed the distinguished guest in the following eloquent words:"Mr. Douglass, permit me on behalf and in the name of your fellow citizens, not only of the District of Columbia, but of our common country, to most cordially congratulate you upon your safe return to the land of your home, to the scenes of your labors, the old arena of your almost matchless triumphs.

"Honored sir, we come to greet you, we come to talk and have you talk with us, we come as old friends, as good neighbors, to shake your honest hand and to congratulate you on your return home from England, France, Germany, from all Europe, from Egypt and the dark continent. Again, sir, we welcome you to your home, your family, and to your friends. Long may you live, far and wide may your influence and usefulness be felt, ever may you be under the fostering care of the great I Am, until time with you shall emerge into the ocean of eternity. I now take great pleas- 
ure in introducing to you Hon. Frederick Douglass."

So hearty and continued was the applause after Mr. Handy's address, that it was some minutes before Mr. Douglass could proceed with his address. At length quiet being restored he came forward and said :-

"Friends, this is indeed an honor which I had not expected. I am certainly a very proud man to-night. Who would not be proud at such a grand ovation as this? I thank you with all my heart; you want to hear something about my trip to Europe and to Egypt, etc. Well, I will commence at the starting point. The passage from New York to Liverpool on the splendid steamer City of Rome, the largest ship afloat except the Great Eastern, was exceedingly pleasant. The winds and waves were in their most amiable mood, and we made the voyage from land to land in seven days. In nothing has there been more progress and improvement than in naval architecture and in navigation. Five and forty years ago fourteen days was a short trip from New York to Liverpool-now it can be made in six days. Fifty years ago the great scientist, Dyonisius Lardner, proved by facts and figures to his own satisfaction, that no vessel could carry enough coal to propel her across the Atlantic, but theories amount to nothing against facts accomplished. The City 
of Rome consumes a ton of coal every five minutes during her voyages. She has sixty furnaces and a crew, including all hands, of two hundred and fifty persons. To walk her decks is like walking a populous street; she is a small town, not on wheels, but on the waves. Our voyage to Liverpool was marked by two incidents in which you will be interested, since they illustrate the gradual wearing away of race prejudice. There was on board the Rev. Henry Wayland, son of the great Dr. Wayland, late president of Brown University. Mr. Wayland had known me years ago, and had been my friend in Rochester. He is one of God's freemen. Through him I was made known to many of the passengers, and this resulted in a strong invitation to address the passengers in the saloon, with which I complied. After this I was called upon by Capt. Monroe to move a vote of thanks in a brief speech to Lord Porchester, who had presided at a concert given in the grand saloon by some talented musicians; thus my privacy was at an end, and I had much talking to do which I could not avoid. The contrast between the treatment I received during this voyage and that of forty years ago, was as striking as it was gratifying. Then I could not obtain a first-class passage-even on a British steamship -and was compelled to go in the forward cabin. Now I found myself not only welcome in the first 
cabin, but treated by everybody with special marks of interest and esteem. It is true, that although I belonged in the forward cabin forty years ago, I made many friends during that voyage, and was then, as on the late voyage, invited to deliver an address on the saloon deck of the Cambria, but I did not comply till invited to do so by the captain. There were several slaveholders on board, and a number of dough-faces from the North. I had hardly been speaking ten minutes when one of the wildest, bitterest, and most devilish rows occurred that I ever saw. It was only put down by the captain calling upon the boatswain to bring up the irons and threatening to put anyone in irons who dared to disturb me. A most unfair account of this outbreak of pro-slavery violence has gone into the history of the Cunard line, denouncing me as the cause of the disturbance on the same principle that the slaves used to be denounced as the cause of the war. The fact is, slaveholders at that time were dictators on sea and land, and the Cunard line, although flying the British flag, found it for their interest to yield to slaveholding dictation, but I believe I am the last man of color proscribed on the Cunard line. I made such a noise in England about it at the time that Samuel Cunard himself publicly declared that there should be no more proscription on his ships on account of race and color. Contempla- 
tion of the forces of nature is enlarging. Standing on the deck of the City of Rome, and moving among its company of passengers so unlike in appearance and character, and then looking out upon the broad, dashing billows of the Atlantic, suggested to my mind the formula that the types of mankind are various. They differ like the waves, but are one like the sea.

\section{The Home Rule Question.}

The features of England are too well known to justify me in saying much about my sojourn in that country. It is common nowadays to speak of England as a declining power in comparison with the rest of the world, and there may be truth in that representation, but the American who travels there will see nothing on the surface to justify that conclusion. Great Britain, though small in territory and limited in population, as compared with our republic, is still Great Britain - great in her civilization, great in physical and mental vigor, great in her statesmanship, and great in her elements of power and stability. The question uppermost when we landed there, as when we left there, was Home Rule, or coercion for Ireland. No question of modern times has stirred England so deeply as this. It has rent asuncler parties, cast down leaders, broken up friendships, and divided families; men who have 
acted together in politics during nearly half a century, have all at once found themselves widely separated on this vast and vital question. There is much strength in the positions of each party, as in the case of our maintenance of our union. I believe that good order, liberty, and civilization will be better served and better preserved in the union of Great Britain and Ireland than outside of it. The spirit of the age does not favor small nationalities. Extension, organization, unification, are more in harmony with the wisdom of the times. The trouble in Ireland, however, is not its limited population, its destitution of statesmen, or its inability to maintain an independent government, but that there is in reality two Irelands; one loyal to the union, and the other anxious for complete separation. The loyal part of the people of Ireland, as a class, are Protestant, and the Home Rule men are largely Catholic; so just here is the bitterest element in the British political cauldron. The Tory party profess to see in Home Rule the entering wedge to the entire separation of Ireland from England, and handing over the whole loyal Protestant population into the power of the hostile Catholic-a result they look upon with unaffected horror. It is this which has caused even the generous and nobleminded John Bright to array his powerful influence against Home Rule. A Republican in 
his sympathies and convictions, he yet shrinks back in horror from applying the Republican majority rule to Ireland. His great friend, Mr. (iladstone, hitherto far more conservative than Mr. Bright, has no such scruples. He seems quite willing to trust the fairness and justice of the majority. He is bitterly reproached for his change of front. It is said he did not always hold his present liberal views towards Ireland, and that his conversion is far too sudden to be grenuine. His answer to this, however, seems to be honest, statesmanlike, and conclusive. He tried coercion for Ireland so long as he thought coercion the only remedy for the ills of that country. He treated Ireland as a wise physician would treat his patient; having his health steadily in vicw, when he found that one course of treatment failed to restore health, he tried another. His method was changed, but his object, never. I hardly need say that I am in sympathy with Home Rule for Ireland, as held by Mr. Gladstone; I am so, both for the sake of England and $f_{0}$ the sake of Ireland. The former will throw off a tremendous load both in money and in reputation by granting it. The glory of England will cease to be suiled with shame for the grievances of Ireland, and Ireland will be put upon her good behavior before the world, and made responsible for her own good or ill condition. Though often 



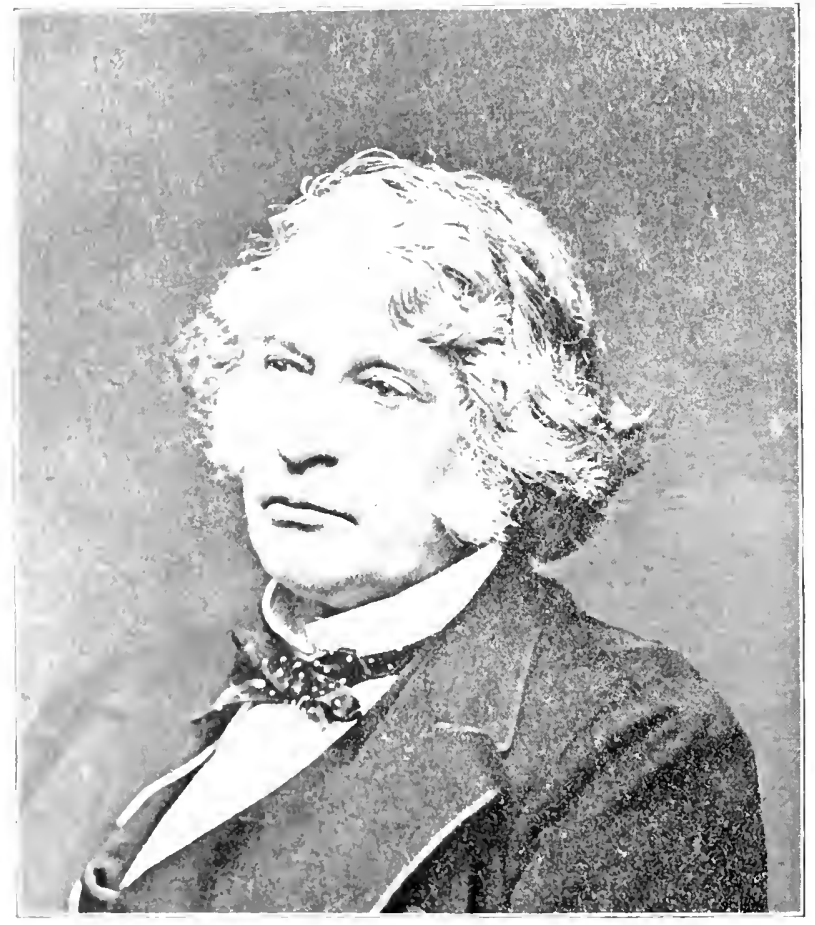

CH.IRIES SINAER. 
charged with seeking the dismemberment of the British Empire, I believe Mr. Gladstone is as firm a friend to the union between England and Ireland as any man in the United Kingdom, but he is for the rule of justice instead of the rule of the bayonet, the rule of love instead of the rule of hate, the rule of trust and confidence instead of the rule of doubt and suspicion. I wanted to see this famous statesman and orator while in London. It has been my good fortune to hear many of the best speakers in this country and in England. I have heard Webster, Everett, Sumner, Phillips, and other great American orators, living and dead. I have also heard Sir Robert Peel, Richard Cobden, George Thompson, John Bright, Lord Brougham, O'Connell, and other great speakers in England, and I felt it would be something to hear the peer of any of the greatest of them. Well, the opportunity was afforded me; I heard Mr. Gladstone, under the most favorable conditions. It was on an occasion of his motion in Parliament to reject the infamous Coercion bill. For weeks the bill had been debated, and Mr. Gladstone had borne his full share in that debate, and I was anxious to know what he could say further. The tide of public opinion set strongly against him, and the passage of the bill was already assured. The press of the country, for the most part, had kept up a steady fire upon 
him and loaded him with reproaches of the bitterest kind. The House was crowded, and all eyes were turned upon him when he rose to make his last great effort to defeat this force bill for Ireland, which he knew could not be defeated; but Mr. Gladstone had a duty to perform and he performed it admirably. The first glance at his face impressed me. There was a singular blending of qualities in it, the lamb and the lion were there; dauntless as a veteran soldier, and yet meek as a saint. His speech was one of the grandest I ever heard, and was listened to with profoundest silence by the whole House. My expectations were high, very high, but in some respects they were far cxceeded. For one hour and a half, without pause, and without once hesitating for a word, he poured out a stream of eloquence, learning, and argument which seemed to be irresistible. When he sat down the government benches, as well as the opposite benches, were immediately emptied, and poor Mr. Balfour, the secretary for Ireland, was left almost without an audience to hear his reply.

My visit to England was in some respects sentimental. I wanted to see the faces and press the hands of some of the dear friends and acquaintances I met there over forty years ago. Among them were two ladies who were mainly instrumental in giving me the chance of devoting 
my life to the cause of freedom. These were Ellen and Anna Richardson, of Newcastle-uponTyne. They are both living, one aged seventynine, and the other over eighty; without any suggestion from me they opened a correspondence with Hon. Walter Foward, of Pittsburgh, and Mr. Merideth, of Philadelphia, and through them bought me out of slavery, secured a bill of sale of my body, made a present of myself to myself, and thus enabled me to return to the United States, and resume my work for the emancipation of the slaves. It was a great privilege to see these two good women, and to see others who assisted them in raising the money to ransom me. If I had no other compensation for my voyage across the sea, this would have been ample payment; of course many of the precious friends who met me in England, Ireland, and Scotland forty years ago have passed away, but I saw some of them through their children and in them recognized their noble qualities.

One of the most interesting places for American tourists is the city of Edinburgh, and it was especially so to me, not only on account of the historical associations that cluster about it, and its many beautiful features, but for the memorable controversy I took part in with the Free Church during my first risit to Scotland. The facts are these: That church had sent a deputa- 
tion to the United States immediately after separating itself from the established church of Scotland, to collect money to build churches and support its ministry. That deputation went South and collected several thousand pounds for this purpose in the slave states and presumably from slaveholders. George Thompson, Henry C. Wright, and James N. Buffom, lately deceased, made an issue with the church. We felt that it would be good testimony against slavery if we could induce the Free Church to follow the example of Daniel O'Connell in a like case to send back the money. The debate was sharp and long-the excitement was great. Nearly everybody in Scotland, outside the Free Church, were on the side of freedom, and were for sending back the money. This sentiment was written on the pavements and walls and sung in the streets by minstrels. The very air was full of send back the money. Forgetting I was in a monarchy and not in this Republic, I got mysclf into trouble by cutting "send back the money" on Arthur's seat. I was soon after arrested for trespassing on the Queen's forests, and only got off by a written apology.

I visited the same spot when over there a few weeks ago, but the friendly grass of forty years had obliterated all trace of the famous formula and my humiliation, as it has also happily blotted out all further need of that sentiment itself. The 
money, however, was never sent back, for Scotchmen do not part with money without knowing wherefor-a lesson which colored people will do well to learn, if they ever favorably change their relations to the people and civilization of our age.

I have traveled since I left, not only in England, Ireland, and Scotland, but in France, Switzerland, Italy, Athens, and Egypt. The most civilized, the best cultivated, and apparently the most prosperous of these countries is England. Nothing here goes to waste, every inch of fertile soil is cultivated and made to yield abundant harvests. The average crop of wheat is forty-six bushels to the acre, exceeding that of our best western lands. Its fields are pictures in frames of rich hedges, adorned with leaves and flowers, its people are well behaved, orderly, and strong, its cattle, large, smooth, and round, its public buildings, substantial and imposing, its houses, neat, ample, and comfortable; everything here exhibits the mark of thoughtful care. The management of its railroads for the comfort of travelers is somewhat clumsy; they lack over there our excellent system of checks, but the protection of life is more complete, and a higher rate of speed is attained; the railroad crossing for teams are spanned by bridges-no teams cross on the rails, and hence nobody is run over as in free America. 
"I stopped but a little while in London, the greatest city, with the greatest population in the world, a population which is just double what it was forty-two years ago. It was two and a half millions then; it is five millions now. I was there long enough to revisit St. Paul's, the National Gallery, the British Museum, IVestminster Abbey, the Tower, Madam Tausaud's, and to visit Buffalo Bill's show,--for this is the latest addition to London life,- - and you would be astonished to see the hundreds of thousands that flock day after day to see this wonder of the Wild liest.

"If any American wants to have a vivid impression of human progress, and to shudder at the cruelty and barbarism of England a few centuries ago, he has only to go to the Tower of London, and look upon the terrible things he will see there - torture and death are written all over that ancient prison. But I must not stop here with England, otherwise I shall hardly reach in my narrative any one of the other great counties it was my good fortune to visit during my stay abroad. Even as the matter now stands, I must postpone to another occasion remarks upon other features of my tour. On leaving London we went directly to Paris and spent several weeks there. We hardly felt ourselves in a strange land and among strangers till we reached this wonder- 
ful city, the center of fashion, taste, refinement, and art, where we no longer heard our mother tongue, or saw our English and American manners. The situation was strange, but not disagreeable. We were in a city of great historical events, marvelous transitions, startling revolutions, where human passion has been more powerfully displayed in riot and ruin than in any other city of modern times. A whole wilderness of horrors is suggested when its name is mentioned, and yet there is found in it quiet, orderly, majestic, and beautiful signs of life, and it is beaming with cheerfulness and thronged with seemingly happy people."

Prolonged applause followed the conclusion of this address, after which the audience filed past Mr. Douglass, each one in turn shaking the hand of the distinguished man.

Mr. Douglass was appointed minister resident and consul general to Hayti by President Harrison in 1889 , and after holding the office for two years resigned. For some years prior to this time the United States had been unsuccessful in its attempts to secure a naval station in Hayti. These efforts, renewed soon after Mr. Douglass had entered upon his duties as minister, were again unsuccessful, and it was claimed that in the negotiations he did not heartily support the propositions made by his government for the 
lease of the môle St. Nicholas. The charge is entirely groundless. In a word, the real objection to granting the request of our government came from the Haytian people themselves. The opinion was general that securing the mole was only the first step in our purpose to annex the whole island to this country. Whether this opinion was correctly founded or not, President Hyppolite, even if he had desired to favor the United States in the matter of leasing the môle, saw it was impolitic to act in defiance to the wishes of his countrymen.

As a proof of its respect and confidence, that government appointed Mr. Douglass to represent the Haytian Republic at the World's Columbian Exposition at Chicago in 1893. 


\section{CHAPTER VIII.}

\section{As Orator and Writer.}

By whatever standard judged Mr. Douglass will take high rank as orator and writer. It may be truly said of him that he was born an orator; and, though he is a man of superior intellectual faculties, he has not relied on his natural powers alone for success in this his chosen vocation. He is called a self-made man, but few college bred men have been more diligent students of logic, of rhetoric, of politics, of history, and general literature than he. He belongs to that class of orators of which Fox of England and Henry and Clay in our own country are the most illustrious representatives. His style, however, is peculiarly his own.

Cicero says, "The best orator is he that so speaks as to instruct, to delight, and to move the mind of his hearers." Mr. Douglass is a striking example of this definition. Few men equal him in his power over an audience. He possesses wit and pathos, two qualities which characterized Cicero and which, in the opinion of the rhetorician Quintilian, gave the Roman orator great advantage over Demosthenes. Judge Ruffin of Boston, in his introduction to Mr. Douglass' autobiography, says: "Douglass is brimful of humor, 
-at times of the driest kind; it is of a quaint kind; you can see it coming a long way off in a peculiar twitch of his mouth; it increases and broadens gradually until it becomes irresistible and all-pervading with his audience." 'The humor of Mr. Douglass is much like that of Mr. Joseph Jefferson, the great actor, who never makes an effort to be funny, but his humor is of the quiet, suppressed type. Like Mr. Jefferson, now he excites those emotions which cause tears, and now he stirs up those which produce laughter. Grief and mirth may be said to reside in adjoining apartments in the same edifice, and the passing from one apartment to the other is not a difficult thing to do.

The biographer of Webster gives the following amusing anecdote to show the simplicity of expressing thought for which that Colossus of American intellect is distinguished in his speeches: "On the arrival of that singular genius, David Crockett, at Washington, he had an opportunity of hearing Mr. Webster. A short time afterwards he met him and abruptly accosted him as follows: 'Is this Mr. Webster?' 'Yes, sir.' 'The great Mr. Webster of Massachusetts?' continued he, with a significant tone. 'I am Mr. Webster of Massachusetts,' was the calm reply. 'Well, sir,' continued the eccentric Crockett, "I had heard that you were a great man, but I don't think so; 
I heard your speech and understood every word you said.'"

President Lincoln gave this reply to the question asked, to what secret he owed his success in public debate: "I always assume that my audiences are in many things wiser than $\mathrm{I}$ am, and I say the most sensible things I can to them. I never found that they did not understand me."

The power of simple statement is one of the chief characteristics of Mr. Douglass' style of speaking, and in this respect he resembles Fox, the great British statesman, who, above all his countrymen, was distinguished on account of plainness, and, as I may express it, homeliness of thought which gave him great power in persuading and moving his audience.

Mr. Douglass' influence in public speaking is due largely to the fact that he touches the hearts of his hearers-that he impresses them with the belief of his sincerity and earnestness. His heart is in what he says. "Clearness, force, and earnestness," says Webster, "are the qualities which produce conviction. True eloquence, indeed, does not consist in speech; it cannot be brought from far; labor and learning may toil for it, but they will toil for it in vain. Words and phrases may be marshaled in every way, but they cannot compass it; it must exist in the man, in the subject, and in the occasion." 
There have been those of brilliant minds who have gained some reputation as speakers; they have been successful in pleasing and amusing those they addressed, but their success stopped here. They could not reach the depths of the heart, because their own hearts were not touched. The poet Horace admirably enforces this thought when he says: "If you wish me to weep, you must first yourself be deeply grieved."

But to be fully appreciated, Mr. Douglass must be seen and heard. This was also true of Henry Clay. One could form but a faint conception of his eloquence and grandeur by reading his speeches, and yet, as reported, they were both logical and argumentative. The fire and action of the man could not be transferred to paper. Mr. Douglass in speaking does not make many gestures, but those he uses are natural and spontancous. His manner is simple and graceful, and there is nothing about his style artificial or declamatory. Much of an orator's success depends upon his delivery. The younger Pitt said that he could not discover where lay his father's eloquence by simply reading his speeches. It is related of Garrick that he was asked by a clergyman why it was that he could produce greater effect by a recital of fiction than the clergy by the presentation of the most important truths. Garrick replied: "Because you speak truths as if 
they were fictions; we speak fictions as if they were truths."

Mr. Douglass, as an extemporaneous speaker, was much more impressive than he has been since he began to write out his speeches and deliver them from manuscript. He remarked to the writer one day that he thought he had made a mistake in thus writing out his lectures; he imbibed the idea that his extemporaneous speeches would be defective and subject him to criticism, He had by so doing lost much power in delivery. "For," said he, "I never was a good reader." The first address he wrote out in full was the paper before the Western Reserve College in I 854. Ever since his return from England in I 860 he has steadily followed the habit of writing what he has to say and reading from manuscript. His former style is what we call extemporaneous, but we do not wish to convey the idea that he spoke without preparation. On the contrary, he gave much thought to the topics which he intended to discuss, and then prepared notes under the different divisions of his subject. By not being confined to his manuscript, he caught the inspiration of his audience. This inspiration, so essential to true eloquence in the orator, can never be secured by the essayist, however finished and perfect he may be.

While Mr. Douglass may have lost much of 
his cloquence in using manuscript, yet some important advantages have resulted from this practice. He was led to investigate more extensively the subjects on which he wrote, and to take more time for preparation; and thus made his speeches more complete. Formerly, many of his best extemporaneous efforts were never fully reported, and consequently much that he said has been lost. His later lectures and speeches have been preserved in manuscript form, and when published together, as they will be one day, will prove a valuable contribution to literature.

Some of his best lectures are The Mission of the VVar, The Sources of Danger to the Republic, Self-made Men, Recollections of the Antislavery Contest, William the Silent, Santo Domingo, The National Capital, Abraham Lincoln, John Brown.

The discourses of Mr. Douglass when reviewed, will bear the test of criticism, and will be found to contain the requisites of a correct and finished style. His language is pure, his words are choice, and in accordance with the best usage. liis sentences are constructed in the English idiom, and have the elements of strength because preference is given in their formation to short Anglo-Saxon words, rather than to those derived from Latin and Greek. So carefully is the rule of propriety observed by him that one would 
think he had thoroughly mastered the principles of grammar and rhetoric under the most competent instructors. From the discrimination he uses in the selection of words to express the idea he wishes to convey, we conclude he must have been for many years a diligent student of the dictionary. His writings are remarkably free from obscurity and affectation, which Macaulay regards as "the two greatest faults in style," and they may, therefore, be taken as models of perspicuity, so essential to one who would become eminent as an essayist. This excellence to which we allude, is due, no doubt, to the fact that he first forms clear and distinct conceptions of the truth he wishes to illustrate, and then making use of simple language to express the ideas arranged in his mind in logical order, writes freely as if under inspiration. Since he has followed the practice of writing his speeches his style has become more argumentative and massive, similar to that of Webster and Burke. In all he says, like these great masters, whom none have surpassed, there is so much beauty of expression, elegance of diction, dignity of thought, and elevation of moral feeling that the most happy and lasting effect is produced upon the mind of the reader.

In the preparation of his speeches and addresses, Mr. Douglass at times requires greater privacy than his library affords, where he is liable 
to interruption by members of his household and visitors. In order that he may wholly give his attention to the literary work which he has in hand, he retires to his "den," as he calls it, a small, one-room building, situated in the rear of his dwelling, and used by former owners as a storehouse, but now with certain interior alterations made into a cozy study. It is a pleasant retreat in summer, for it is protected from the heat of the sun by trees and vines, and in winter is made comfortable by a glowing fire in the oldfashioned fireplace found within. The study is furnished simply with a lounge, a high desk, and a stool. It is the practice of Mr. Douglass to write standing, when in this room, where he will remain for hours at a time, denying himself to all visitors. While composing, he thinks accurately and correctly, and on this account his composition requires but little correction. His manuscript is always neat, not marred by erasures and alturations. We mention this fact because it proves that correct writing is the result of care exercised by the writer in the beginning, which in time becomes a fixed habit. 


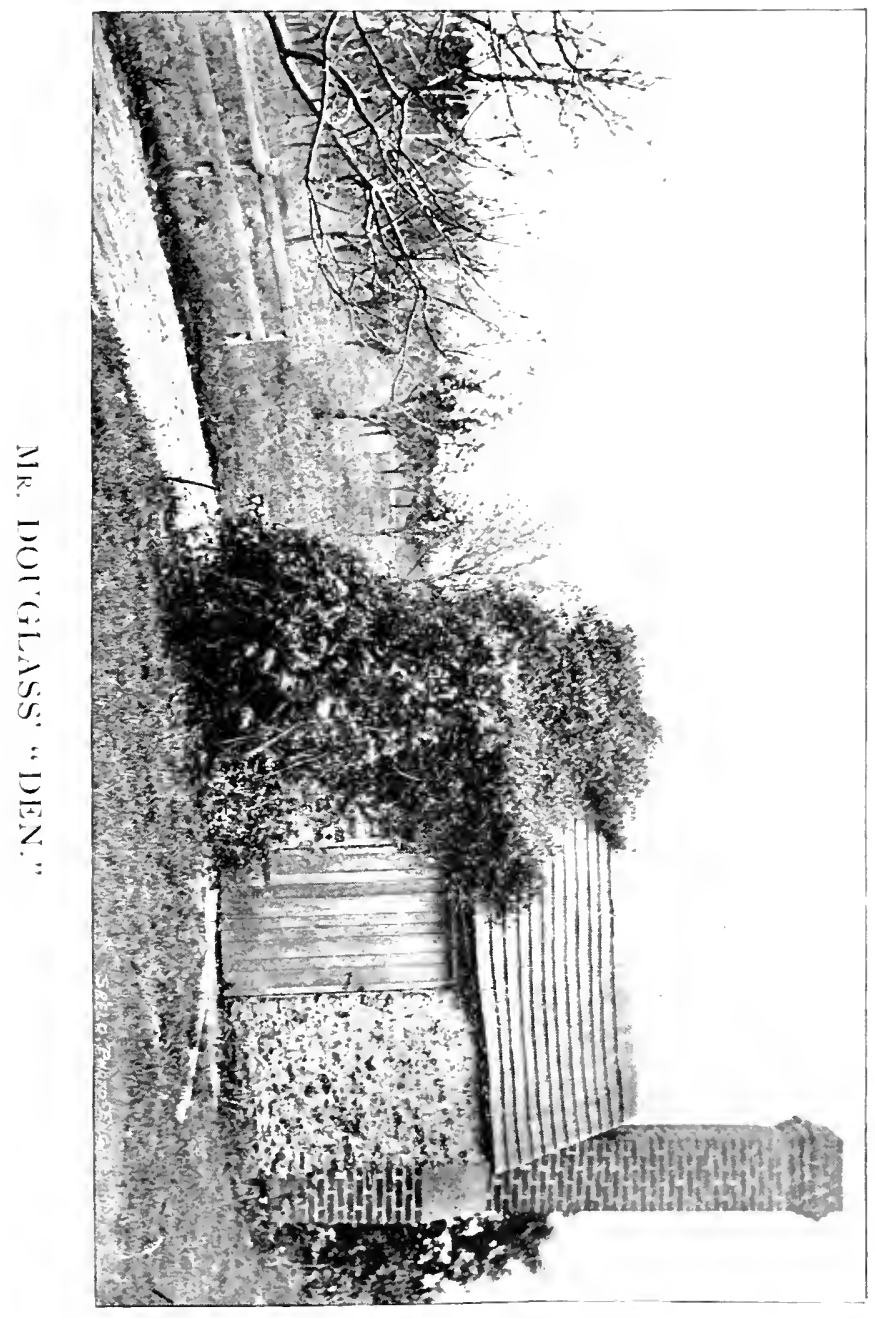





\section{CHAPTER IX.}

Extracts from His Speeches and Lectures.

We shall now make a few additional selections from his speeches and lectures to show further his style as orator and writer. We regret we have no exact report of the Nantucket speech, to which reference in these pages has already been made. This was his maiden effort and was the turning point of his whole life. I quote from Mr. Garrison, who was in attendance upon the convention, and heard the addresses of the different speakers. After telling of the fortunate circumstance that $\mathrm{Mr}$. Douglass was induced to address the meeting, he gives the impressions made upon him by the speaker in his remarks on that occasion. Here is what he says :-

"Fortunate, most fortunate occurrence!-fortunate for the millions of his manacled brethren, yet panting for deliverance from their awful thraldrom! fortunate for the cause of negro emancipation, and of universal liberty! fortunate for the land of his birth, which he has already done so much to save and bless! fortunate for a large circle of friends and acquaintances, whose sympathy and affection he has strongly secured by the many sufferings he has endured, by his virtuous 
traits of character, by his ever-abiding remembrance of those who are in bonds, as being bound with them! fortunate for the multitudes, even in various parts of our republic, whose minds he has enlightened on the subject of slavery, and who have been melted to tears by his pathos, or roused to virtuous indignation by his stirring eloquence against the enslavers of men! fortunate for himself, as it at once brought him into the field of public usefulness, 'gave the world assurance of a man,' quickened the slumbering energies of his soul, and consecrated him to the great work of breaking the rod of the oppressor, and letting the oppressed go free!

"I shall never forget his first speech at the convention-the extraordinary emotion it excited in my own mind-the powerful impression it created upon a crowded auditory, completely taken by surprise-the applause which followed from the beginning to the end of his felicitous remarks. I think I never hated slavery so intensely as at that moment; certainly my perception of the enormous outrage which is inficted by it, on the Godlike nature of its victims, was rendered far more clear than ever. There stood one in physical proportion and stature commanding and exact, in intellect richly endowed, in natural eloquence a prodigy, in soul manifestly 'created but a little lower than the angels'-yet a slave, ay, a fugitive 
slave, trembling for his safety, hardly daring to believe that on the American soil a single white person could be found who would befriend him at all hazards, for the love of God and humanity! As soon as he had taken his seat, filled with hope and admiration, I arose and declared that Patrick Henry, of Revolutionary fame, never made a speech more eloquent in the cause of liberty than the one we had just listened to from the lips of that hunted fugitive. So I believed at that time, such is my belief now."

Afterwards $\mathrm{Mr}$. Douglass, referring to the remarks he made on this occasion, said that he had no idea that he was making much of an effort. Getting over his embarrassment, he caught the spirit of the meeting and somehow words came to him spontaneously.

Mr. Douglass in December, I $\$_{4} 1$, made an anti-slavery speech in Providence, Rhode Island. This speech, like the Nantucket one, was never written out or fully reported. We give the account of it as furnished by that elegant writer, N. P. Rogers.

"Friday evening was chiefly occupied by colored speakers. The fugitive Douglass was up when we entered. This is an extraordinary man. $\mathrm{He}$ was cut out for a hero. In a rising for liberty he would have been a Toussaint or a Hamilton. He has the "heart to conceive, the head to 
contrive, and the hand to execute!' A commanding person-over six feet, we should say, in height, and of most manly proportions. His head would strike a phrenologist amid a sea of them in Exeter Hall, and his voice would ring like a trumpet in the field. Let the South congratulate herself that he is a fugitive. It would not have been safe for her if he had remained about the plantations a year or two longer. Douglass is his fugitive name. He did not wear it in slavery. We do not know why he assumed it, or who bestowed it on him, but there is some fitness in it, to his commanding figure and heroic part. As a speaker he has few equals. It is not declamation, but oratory, power of debate. He watches the tide of discussion with the eye of the veteran, and dashes into it at once with all the tact of the forum or the bar. He has wit, argument, sarcasm, pathos-all that first-rate men show in their master efforts. His voice is highly melodious and rich, and his enunciation quite elegant, and yet he has been but two or three years out of the house of bondage. We noticed that he had strikingly improved, since we heard him at Dover in September. We say this much of him, for he is esteemed by our multitude as of an inferior race. We should like to see him before any New England legislature or bar, and let him feel the freedom of the anti-slavery meeting, and see 
what would become of his inferiority. Yet he is a thing, in American estimate. He is the chattel of some pale-faced tyrant. How his owner would cower and shiver to hear him thunder in an antislavery hall! How he would shrink away, with his infernal whip, from his flaming eye when kindled with anti-slavery emotion! And the brotherhood of thieves, the posse comitatus of divines, we wish a hecatomb or two of the proudest and flintiest of them were obliged to hear him thunder for human liberty and lay the enslavement of his people at their doors. They would tremble like Belshazzar."

Of his early speeches here is an eloquent extract upon

\section{“Man's Rigits to Liberty.}

"Indeed, I ought to state, what must be obvious to all, that, properly speaking, there is no such thing as new truth; for truth, like the God whose attribute it is, is eternal. In this sense, there is, indeed, nothing new under the sun. Error may be properly designated as old or new, since it is but a misconception; or an incorrect view of the truth. Misapprehensions of what truth is have their beginnings and their enclings. They pass away as the race move onward. But truth is 'from everlasting to everlasting,' and can never pass away. 
"Such is the truth of man's right to liberty. It existed in the very idea of man's creation. It was his even before he comprehended it. He was created in it, endowed with it, and it can never be taken from him. No laws, no statutes, no compacts, no covenants, no compromises, no constitutions, can abrogate or destroy it. It is beyond the reach of the strongest earthly arm, and smiles at the ravings of tyrants from its hiding place in the bosom of God. Men may hinder its exercise, they may act in disregard of it, they are even permitted to war against it; but they fight against heaven, and their career must be short, for Eternal Providence will speedily vindicate the right.

"The existence of this truth is self-evident. It is written upon all the powers and faculties of man. The desire for it is the deepest and strongest of all the powers of the human soul. Earth, sea, and air,-great Nature, with her thousand voices, proclaim it. In the language of Addison we may apostrophize it:-

“.' Oh, Liberty' thou goddess, heavenly bright, l'rofuse of bliss, and pregnant with delight! Thou mak'st the glowing face of nature gay, (iiv'st beauty to the sun, and pleasure to the day.'

"I have said that the right to liberty is self-evid.nt. No argument, no researches into mouldy records, no learned disquisitions, are necessary 
to establish it. To assert it, is to call forth a sympathetic response from every human heart, and to send a thrill of joy and gladness round the world. Tyrants, oppressors, and slaveholders are stunned by its utterance, while the oppressed and enslaved of all lands hail it as an angel of deliverance. Its assertion in Russia, in Austria, in Egypt, in fifteen states of the American Union, is a crime. In the harems of Turkey, and on the Southern plantations of Carolina, it is alike prohibited; for the guilty oppressors of every clime understand its truth, and appreciate its electric power."

The following extract, a model of passionate eloquence, is from an oration delivered on the Fourth of July, 1852, to the citizens of Rochester.

"The Winte Man's Fourth of July.

"To me the American slave-trade is a terrible reality. When a child, my soul was often pierced with a sense of its horrors. I lived on Philpot street, Fells Point, Baltimore, and have watched from the wharves the slave-ships in the basin, anchored from the shore, with their cargoes of human flesh, waiting for favorable winds to waft them down the Chesapeake. There was at that time a grand slave-mart kept at the head of Pratt street, by Austin Woldfolle. His agents were sent into every town and county in Maryland, 
announcing their arrival through the papers, and on flaming 'handbills,' headed, Cash for Negroes. These men were generally well dressed, and very captivating in their manners, ever ready to drink, to treat, and to gamble. The fate of many a slave has depencled upon the turn of a single card; and many a child has been snatched from the arms of its mother, by bargains arranged in a state of brutal clrunkenness.

"The fleshmongers gather up their victims by dozens, and drive them, chained, to the general depot at Baltimore. When a sufficient number have been collected here, a ship is chartered for the purpose of conveying the forlorn crew to Mobile, or to New Orleans. From the slave prison to the ship, they are usually driven in the darkness of night; for since the anti-slavery agitation, a certain caution is observed.

"In the deep, still darkness of midnight, I have often been aroused by the dead, heavy footsteps, and the piteous cries of the chained gangs that passed our door. The anguish of my boyish heart was intense, and I was often consoled, when speaking to my mistress in the morning, to hear her say that the custom was very wicked; that she hated to hear the rattle of the chains, and the heart-rending cries. I was glad to find one who sympathized with me in my horror.

"I ellow-citizens, this murderous traffic is, to- 
day, in active operation in this boasted republic. In the solitude of my spirit, I see clouds of clust raised on the highways of the South; I see the bleeding footsteps; I hear the doleful wail of fettered humanity, on the way to the slave-markets, where the victims are to be sold like horses, sheep, and swine, knocked off to the highest bidder. There I see the tenderest ties ruthlessly broken to gratify the lust, caprice, and rapacity of the buyers and sellers of men. My soul sickens at the sight.

* * * * * * * * * *

"What, to the American slave, is your Fourth of July? I answer, a day that reveals to him, more than all other days in the year, the gross injustice and cruelty to which he is the constant victim. To him, your celebration is a sham; your boasted liberty, an unholy license; your national greatness, swelling vanity; your sounds of rejoicing are empty and heartless; your denunciations of tyrants, brass-fronted impudence; your shouts of liberty and equality, hollow mockery; your prayers and hymns, your sermons and thanksgivings, with all your religious parade and solemnity, are, to him, mere bombast, fraud, deception, impiety, and hypocrisy - a thin veil to cover up crimes which would disgrace a nation of savages. There is not a nation on the earth guilty of practices more shocking and more bloody than 
are the people of these United States at this very hour."

At the commencement exercises of the Western Reserve College, July 1 2, i $S_{54}, \mathrm{Mr}$. Douglass ably discussed the question, "The Claims of the Negro Ethnologically Considered." As stated elsewhere in this sketch, up to this time he had delivered his speeches extemporaneously or from brief notes. On this occasion he wrote out in full his address and spoke from manuscript, introducing his subject to the audience in these words :-

"Gentlemen of the Philozetian Society: I propose to submit to you a few thoughts on the subject of the Claims of the Negro, suggested by ethmological science, or the natural history of man. But, before entering upon that subject, I trust you will allow me to make a remark or two somewhat personal to myself. The relation between me and this occasion may justify what, in others, might seem an offense against good taste.

"This occasion is to me of no ordinary interest, for many reasons; and the honor you have done me, in selecting me as your speaker, is as grateful to my heart as it is novel in the history of American collegiate or literary institutions. Surprised as I am, the public are no less surprised, at the spirit of independence, and the moral 
courage displayed by the gentlemen at whose call I am here. There is felt to be a principle in the matter placing it far above egotism or personal vanity; a principle which gives to this occasion a general, and, I had almost said, an universal interest. I engage, to-day, for the first time, in the exercises of any college commencement. It is a new chapter in my humble experience. The usual course, at such times, I believe, is to call to the platform men of age and distinction, eminent for eloquence, mental ability, and scholarly attainments-men whose high culture, severe training, great experience, large observation, and peculiar aptitude for teaching, qualify them to instruct even the already well instructed, and to impart a glow, a luster, to the accuirements of those who are passing from the halls of learning to the broad theater of active life. To no such high endeavor as this, is your humble speaker fitted; and it was with much distrust and hesitation that he accepted the invitation, so kindly and perseveringly given, to occupy a portion of your attention here to-day.

"I express the hope, then, gentlemen, that this acknowledgment of the novelty of my position, and my unaffected and honest confession of inaptitude, will awaken a sentiment of generous indulgence towards the scattered thoughts I have been able to fling together, with a view of pre- 
senting them as my humble contribution to these commencement exercises.

"Interesting to me, personally, as this occasion is, it is still more interesting to you; especially to such of you as have completed your education, and who (not wholly unlike the gallant ship, newly launched, full rigged, and amply fitted, about to quit the placid waters of the harbor for the boisterous waves of the sea) are entering upon the active dutics and measureless responsibilities incident to the great voyage of life. Before such, the ocean of mind lies outspread more solemn than the sea, studded with difficulties and perils. 'Thoughts, theories, ideas, and systems, so various, and so opposite, and leading to such diverse results, suggest the wisdom of the utmost precaution, and the most careful survey, at the start. A false light, a defective chart, an imperfect compass, may cause one to drift in endless bewilderment, or to be landed at last amid sharp destructive rocks. On the other hand, guided by wisdom, manned with truth, fidelity and industry, the haven of peace, devoutly wished for, may be reached in safety by all. The compensation of the preacher is full, when assured that his words have saved even one from error and from ruin. My joy shall be full, if, on this occasion, I shall be able to grive a right direction to any one mind, touching the question now to be considered. 
"Gentlemen, in selecting the Claims of the $\mathrm{Ne}$ gro as the subject of my remarks to-day, I am animated by a desire to bring before you a matter of living importance-matter upon which action, as well as thought, is required. The relation subsisting between the white and black people of this country is the vital question of the age. In the solution of this question, the scholars of America will have to take an important and controlling part. This is the moral battlefield to which their country and their God now call them. In the eye of both, the neutral scholar is an ignoble man. Here, a man must be hot, or be accounted cold, or, perchance, something worse than hot or cold. The lukewarm and the cowardly will be rejected by earnest men on either side of the controversy. The cunning man who avoids it, to gain the favor of both parties, will be rewarded with scorn; and the timid man who shrinks from it for fear of offending either party, will be despised. To the lawyer, the preacher, the politician, and to the man of letters, there is no neutral ground. He that is not for us, is against us. Gentlemen, I assume at the start, that wherever else I may be required to speak with bated breath, here, at least, I may speak with freedom the thought nearest my heart. This liberty is implied, by the call I have received to be here; and yet I hope to present the subject so 
that no man can reasonably say that an outrage has been committed, or that I have abused the privileges with which you have honored me. I shall aim to discuss the claims of the negro, general and special, in a manner, though not scientific, still sufficiently clear and definite to enable my harers to form an intelligent judgment respecting them."

$$
\text { * * * * * * * * * * * }
$$

He concludes in the following eloquent plea in behalf of his race :-

"But, grentlemen, the time fails me, and I must bring these remarks to a close. My argument has swelled beyond its appointed measure. What I intended to make special, has become, in its progress, somewhat general. I meant to speak here, to-day, for the lonely and the despised ones, with whom I was cradled, and with whom I have suffered; and now, gentlemen, in conclusion, what if all this reasoning be unsound? What if the negro may not be able to prove his relationship to Nubians, Abyssinians, and Egyptians? What if ingenious men are able to find plausible objections to all arguments maintaining the oneness of the human race? What, after all, if they are able to show very good reasons for believing the negro to have been created precisely as we find him on the Gold coast-along the Senegal and the Niger -I say, what of all this? 'A man's a man for 
a' that.' I sincerely believe, that the weight of the argument is in favor of the unity of origin of the human race, or species-that the arguments on the other side are partial, superficial, utterly subversive of the happiness of man, and insulting to the wisdom of God. Yet, what if we grant they are not so? What, if we grant that the case, on our part, is not made out? Does it follow, that the negro should be held in contempt? Does it follow, that to enslave and imbrute him is either just or wise? I think not. Human rights stand upon a common basis; and by all the reason that they are supported, maintained, and defended, for one variety of the human family, they are supported, maintained, and defended for all the human family; because all mankind have the same wants, arising out of a common nature. A diverse origin does not disprove a common nature, nor does it disprove a united destiny. The essential characteristics of humanity are everywhere the same. In the language of the eloquent Curran, 'No matter what complexion, whether an Indian or an African sun has burnt upon him,' his title cleed to freedom, his claim to life and to liberty, to knowledge and to civilization, to society and to Christianity, is just and perfect. It is registered in the courts of heaven, and is enforced by the eloquence of the God of all the earth.

"I have said that the negro and white man are 
likely ever to remain the principal inhabitants of this country. I repeat the statement now, to submit the reasons that support it. The blacks can clisappear from the face of the country by three ways. They may be colonized,-they may be exterminated,-or, they may die out. Colonization is out of the question, for I know not what hardships the laws of the land can impose which can induce the colored citizen to leave his native soil. He was here in its infancy; he is here in its age. Two hundred years have passed over him, his tears and blood have been mixed with the soil, and his attachment to the place of his birth is stronger than iron. It is not probable that he will be exterminated; two considerations must prevent a crime so stupendous as that-the influence of Christianity on the one hand, and the power of self-interest on the other; and, in regard to their dying out, the statistics of the country afford no encouragement for such a conjecture. The history of the negro race proves them to be wonderfully adapted to all countries, all climates, and all conditions. Their tenacity of life, their powers of endurance, their malleable toughness, would almost imply especial interposition on their behalf. The ten thousand horrors of slavery, striking hard upon the sensitive soul, have bruised, and battered, and stung, but have not killed. The poor bondman lifts a smiling 
face above the surface of a sea of agonies, hoping on, hoping evor. His tawny brother, the Indian, dies under the flashing glance of the AngloSaxon. Not so the negro; civilization cannot kill him. He accepts it-becomes a part of it. In the church, he is an Uncle Tom; in the state, he is the most abused and least offensive. All the facts in his history mark out for him a destiny united to America and Americans. Now, whether this population shall, by FrEEDOM, IndusTRY, ViRTUe, and InTelligence, be made a blessing to the country and the world, or whether their multiplied wrongs shall kindle the vengeance of an offended God, will depend upon the conduct of no class of men so much as upon the scholars of the country. The future public opinion of the land, whether anti-slavery or pro-slav. ery, whether just or unjust, whether magnanimous or mean, must redound to the honor of the scholars of the country or cover them with shame. There is but one safe road for nations or for individuals. The fate of a wicked man and of a wicked nation is the same. The flaming sword of offended justice falls as certainly upon the nation as upon the man. God has no children whose rights may be safely trampled upon. The sparrow may not fall to the ground without the notice of his eye, and men are more than sparrows. "Now, gentlemen, I have done. The subject is 
before you. I shall not undertake to make the application. I speak as unto wise men. I stand in the presence of scholars. We have met here to-day from vastly different points in the world's condition. I have reached here-if you will pardon the egrotism-by little short of a miracle; at any rate, by dint of some application and perseverance. Borm, as I was, in obscurity, a stranger to the halls of learning, environed by ignorance, degradation, and their concomitants from birth to manhood, I do not feel at liberty to mark out, with any degree of confidence, or dogmatism, what is the precise vocation of the scholar. Yet, this I can say, as a denizen of the world, and as a citizen of a country rolling in the sin and shame of slavery, the most flagrant and scandalous that ever saw the sun, "Whatsoever things are true, whatsocver things are honest, whatsoever things are just, whatsoever things are pure, whatsoever things are lovely, whatsoever things are of good report, if there be any virtue, and if there be any praise, think on these things.' "

A gentleman who was present and heard this address, in a recent article to a newspaper writes the following: "One of the societies in "Western Reserve College' (now removed to Cleveland, and known as Adelbert College, and endowed by the late Mr. Stone) had invited Mr. Douglass to give the annual address before that body. It was a 
very honorable exhibition of breadth and progressiveness on the part of the students. The Western Reserve was always in advance, keeping step with Worcester county, Massachusetts. Mr. Douglass took as his subject, "The Claims of the Negro Ethnologically Considered.' The honored president of the University of Rochester kindly and cordially promised to give Mr. Douglass the benefit of his extended knowledge of ethnology, and it was the privilege of the Rambler to accompany Mr. Douglass to the house of the president and to introduce (as an isthmus connecting two continents) the radical lecturer to the somewhat conservative president. Later it was his honor to introduce Mr. Douglass to the president of Brown University.

"In the course of his address, Mr. Douglass cited one author who decried the claim of the negro to equal manhood, on the ground that 'the voice of the negro is thin and piping, an evidence of inferiority.' This passage Mr. Douglass delivered in a voice of thunder, convulsing the audience, and rendering other reply needless."

Mr. George Thompson, whom Lord Brougham called "the most eloquent man in all England," had argued before the people of Glasgow, Scotland, that the constitution of the United States was a pro-slavery instrument, and took the ground that the dissolution of the Union as held by the 
Garrisonians was the end to be sought by the American abolitionists as opposed to those who believed in the anti-slavery character of the constitution and duty of laboring inside of the government for the abolition of slavery. Mr. Douglass, then being in Glasgow, was invited to answer Mr. Thompson, and did so in a speech which showed not only his ability as a ready debater, but his thorough understanding of the question he discussed. The extract which we here present of that speech will give some idea of his power of simple statement and force of logical reasoning :-

"I have read with much care a speech delivered in the City Hall, Glasgow, on the 28 th of February, purporting to be a reply to one made by myself in Dr. Anderson's church a few weeks previously. I found that speech at length in one of your most respectable daily papers. The minuteness and general shading of the report bore evidence that the orator had been his own reporter. The speech showed no marks of being marred or mutilated in its transition from the manuscript to the types, and no doubt may be properly taken as a fair transcript of the orator's utterances on that occasion. On some accounts I read that speech with much regret, and on others with much satisfaction. I was certainly pleased with the evidence it afforded that the orator had largely recovered his long-lost health, 
and much of his wonted eloquence and fire. But my chief ground of satisfaction is that its delivery-perhaps I ought to say its publication, for I should not have noticed the speech but for thatfurnishes an occasion for bringing before the friends of my enslaved people one phase of the great struggle going on in America between slavery and freedom, which I deem both interesting and important.

"I stand by all I said, and more than all I said, in the speech in Dr. Anderson's church. But enough of this; I proceed to the discussion. Much will be gained at the outset if we fully and clearly understand the real question under discussion. Indeed, nothing is or can be understood till this is understood. Things are often confounded and treated as the same, for no better reason than that they resemble each other, even while they are in their nature and character totally distinct and even directly opposed to each other. The jumbling of things is a sort of dustthrowing which is often indulged in by small men who argue for victory rather than for truth. Thus, for instance, the American government and the American constitution are spoken of in a manner which would naturally lead the hearer to believe that the one is iclentical with the other; when the truth is, they are as distinct in charac- 
ter as are a ship and a compass. The one may point right and the other steer wrong. A chart is one thing, the course of the vessel is another. The constitution may be right, the government wrong. If the government has been governed by mean, sordid, and wicked passions, it does not follow that the constitution is mean, sordid, or wicked. What, then, is the question? I will state it. But first let me state what is not the question. It is not whether slavery existed in the United States at the time of the adoption of the constitution; it is not whether slaveholders took part in framing the constitution; it is not whether those slaveholders, in their hearts, intended to secure certain advantages in that instrument for slavery; it is not whether the American government has been wielded during seventy-two years in favor of the propagation and permanence of slavery; it is not whether a pro-slavery interpretation has been put upon the constitution by the American courts-all these points may be true, or they may be false, they may be accepted or they may be rejected, without in any way affecting the real question in debate. The real and exact question between myself and the class of persons represented by the speech at the City Hall may be fairly stated thus: First, does the United Siates constitution guarantee to any class or description of people in that country the right 
to enslave, or hold as property, any other class or description of people in that country? Sccond, is the dissolution of the union between the slave and free states required by fidelity to the slaves or by the just demands of conscience? Or, in other words, is the refusal to exercise the elective franchise, and to hold office in America, the surest, wisest, and best way to abolish slavery in America? To these questions the Garrisonians say, yes. They hold the constitution to be a slaveholding instrument, and will not cast a vote or hold office, and denounce all who vote or hold office, no matter how faithfully such persons labor to promote the abolition of slavery. I, on the other hand, deny that the constitution guarantees the right to hold property in man, and believe that the way to abolish slavery in America is to vote such men into power as will use their powers for the abolition of slavery. This is the issue plainly stated, and you shall judge between us. Before we examine into the disposition, tendency, and character of the constitution, I think we had better ascertain what the constitution itself is. Before looking for what it means, let us see what it is. Here, too, there is much dust to be cleared away. What, then, is the constitution? I will tell you. It is no vague, indefinite, floating, unsubstantial, ideal something, colored according to any man's fancy, now a weasel, now a whale, and 
now nothing. On the contrary, it is a plainly written clocument, not in Hebrew or Greek, but in English, beginning with a preamble, filled out with articles, sections, provisions, and clauses, defining the rights, powers, and duties to be secured, claimed, and exercised under its authority. It is not even like the British constitution, which is made up of enactments of Parliament, decisions of courts, and the established usages of the government. The American constitution is a written instrument full and complete in itself. No court in America, no Congress, no president, can add a single word thereto, or take a single word therefrom. It is a great national enactment clone by the people, and can only be altered, amended, or added to, by the people.

* * * * * * * * * * *

"I repeat, the paper itself, and only the paper itself, with its own plainly-written purposes is the constitution. It must stand or fall, flourish or fade, on its own individual and self-declared character and objects. Again, where would be the advantage of a written constitution, if, instead of seeking its meaning in its words, we had to seek them in the secret intentions of individuals who may have had something to do with writing the paper? What will the people of America a hundred years hence care about the intentions of the scriveners who wrote the constitution? These 
men are already gone from us, and in the course of nature were expected to go from us. They were for a generation, but the constitution is for ages. Whatever we may owe to them, we certainly owe it to ourselves, and to mankind, and to God, to maintain the truth of our own language, and to allow no villainy, not even the villainy of holding men as slaves--which Wesley says is the sum of all villainies-to shelter itself under a fair-seeming and virtuous language. We owe it to ourselves to compel the devil to wear his own garments, and to make wicked laws speak out their wicked intentions. Common sense, and common justice, and sound rules of interpretation, all clrive us to the words of the law for the meaning of the law." 


\section{CHAPTER X.}

Extracts from his Speeches and LecturesContinued.

ON Decoration day, is7 I, Mr. Douglass deliv. ered an address before a great concourse of people, including General Grant and his cabinet, in which he distinctly points out the motives which actuated those who fought on opposite sides in the late civil conflict. It is, perhaps, the best of his short speeches, and we think there cannot be found a more just and eloquent tribute to our illustrious dead. Here is what he said :-

"Friends and Fellow Citizens: Tarry here for a moment. My words shall be few and simple. The solemn rites of this hour and place call for no lengthened speech. There is, in the very air of this resting-ground of the unknown dead, a silent, subtle, and all pervading eloquence, far more touching, impressive, and thrilling than living lips have ever uttered. In to the measureless depths of every loyal soul it is now whispering lessons of all that is precious, priceless, holiest, and most enduring in human existence.

"Dark and sad will be the hour to this nation when it forgets to pay grateful homage to its grcatest benefactors. The offering we bring to- 
day is due alike to the patriot soldiers dead and their noble comrades who still live; for, whether living or dead, whether in time or eternity, the loyal soldiers who imperiled all for country and freedom are one and inseparable.

"Those unknown heroes whose whitened bones have been piously gathered here, and whose green graves we now strew with sweet and beautiful flowers, choice emblems alike of pure hearts and brave spirits, reached, in their glorious career, that last highest point of nobleness beyond which human power cannot go. They died for their country.

"No loftier tribute can be paid to the most illustrious of all the benefactors of mankind than we pay to these unrecognized soldiers when we write above their graves this shining epitaph.

"When the dark and vengeful spirit of slavery, always ambitious, preferring to rule in hell than to serve in heaven, fired the Southern heart and stirred all the malign elements of discord, when our great republic, the hope of freedom and selfgovernment throughout the world, had reached the point of supreme peril, when the union of these states was torn and rent asunder at the center, and the armies of a gigantic rebellion came forth with broad blades and bloody hands to destroy the very foundation of American society, the unknown heroes who flung themselves 
in to the yawning chasm, amid roaring cannon and whistling bullets, with a sublime devotion fought and died for their country.

"VVe are sometimes asked, in the name of patriotism, to forget the merits of this fearful struggle, and to remember with equal admiration those who struck at the nation's life and those who struck to save it, those who fought for slavery and those who fought for liberty and justice.

"I am no minister of malice. I would not strike the fallen. I would not repel the repentant; but may 'my right hand forget her cunning, and my tongue cleave to the roof of my mouth,' if I forget the difference between the parties to that terrible, protracted, and bloody conflict.

"If we ought to forget a war which has filled our land with widows and orphans; which has made stumps of men of the very flower of our youth ; which has sent them on the journey of life armless, legless, maimed, and mutilated; which has piled up a debt heavier than a mountain of gold, swept uncounted thousands of men into bloody graves and planted agony at a million hearthstones-I say, if this war is to be forgotten, I ask, in the name of all things sacred, what shall men remember?

"The essence and significance of our devotions here to day are not to be found in the fact that the men whose remains fill these graves were 
brave in battle. If we met simply to show our sense of bravery, we should find enough on both sides to kindle admiration. In the raging storm of fire and blood, in the fierce torrent of shot and shell, of sword and bayonet, whether on foot or on horse, unflinching courage marked the rebel not less than the loyal soldier.

"But we are not here to applaud manly courage, save as it has been displayed in a noble cause. We must never forget that victory to the rebellion meant death to the republic. We must never forget that the loyal soldiers who rest beneath this sod flung themselves between the nation and the nation's destroyers. If to-day we have a country not boiing in an agony of blood, like France, if now we have a united country, no longer cursed by the hell-black system of human bondage, if the American name is no longer a by-word and a hissing to a mocking earth, if the star spangled banner floats only over free American citizens in every quarter of the land, and our country has before it a long and glorious career of justice, liberty, and civilization, we are indebted to the unselfish devotion of the noble army who rest in these honored graves all around us."

On the 14 th of April, 1876, on the occasion of the unveiling of the Freedmen's monument in memory of Abraham Lincolin in Lincoln park, Washington, D. C., Mr. Douglass was the orator 
of the day, and in his masterly oration spoke eloquently of the life and services of President Lincoln. We give the concluding portion of what he said :-

"Fellow-citizens, whatever else in this world may be partial, unjust, and uncertain, time, time! is impartial, just, and certain in its action. In the realm of mind, as well as in the realm of matter, it is a great worker, and often works wonders. The honest and comprehensive statesman, clearly discerning the needs of his country, and earnestly endeavoring to do his whole duty, though covered and blistered with reproaches, may safely leave his course to the silent judgment of time. Few great public men have ever been the victims of fiercer denunciation than Abraham Lincoln was during his administration. He was often wounded in the house of his friends. Reproaches came thick and fast upon him from within and from without, and from opposite quarters. He was assailed by abolitionists; he was assailed by slaveholders; he was assailed by the men who were for peace at any price; he was assailed by those who were for a more vigorous prosecution of the war; he was assailed for not making the war an abolition war; and he was most bitterly assailed for making the war an abolition war.

"But now behold the change; the judgment of the present hour is, that taking him for all in all, 
measuring the tremendous magnitude of the work before him, considering the necessary means to ends, and surveying the end from the beginning, infinite wisdom has seldom sent any man into the world better fitted for his mission than Abraham Lincoln. His birth, his training, and his natural endowments, both mental and physical, were strongly in his favor. Born and reared among the lowly, a stranger to wealth and luxury, compelled to grapple single-handed with the flintiest hardships of life from tender youth to sturdy manhood, he grew strong in the manly and heroic qualities demanded by the great mission to which he was called by the votes of his countrymen. The hard condition of his early life, which would have depressed and broken down weaker men, only gave greater life, vigor, and buoyancy to the heroic spirit of Abraham Lincoln. He was ready for any kind and any quality of work. What other young men dreaded in the shape of toil, he took hold of with the utmost cheerfulness.

\section{" A spade, a rake, a hoe,}

A pickaxe, or a bill;

A hook to reap, a scythe to mow,

A flail, or what you will.'

"All day long he could split heavy rails in the woods, and half the night long he could study his English grammar by the uncertain flare and glare of the light made by a pine knot. He was at 
home on the land with his axe, with his maul, with gluts, and his wedges; and he was equally at home on water, with his oars, with his poles, with his planks, and with his boat-hooks. And whether in his flat-boat on the Mississippi river, or at the fireside of his frontier cabin, he was a man of work. A son of toil himself, he was linked in brotherly sympathy with the sons of toil in every loyal part of the republic. This very fact gave him tremendous power with the American people, and materially contributed not only to electing him to the presidency, but in sustaining his administration of the government.

"Upon his inauguration as president of the United States, an office, even where assumed under the most favorable conditions, fitted to tax and strain the largest abilities, Abraham Lincoln was met by a tremendous crisis. He was called upon not merely to administer the government, but to decicle, in the face of terrible odds, the fate of the republic. A formidable rebellion rose in his path before him ; the Union was already practically dissolved; his country was torn and rent asunder at the center. Hostile armies were already organized against the republic, armed with the munitions of war which that republic had provided for its own defense. The tremendous question for him to decide was whether his country should survive the crisis and flourish, or be 
dismembered and perish. His predecessor in office had already decided the question in favor of national dismemberment by denying to it the right of self-defense and self-preservation-a right which belongs to the meanest insect.

"Happily for the country, happily for you and for me, the judgment of James Buchanan, the patrician, was not the judgment of Abraham Lincoln, the plebeian. He brought his strong common sense, sharpened in the school of adversity, to bear upon the question. He did not hesitate, he did not falter; but at once resolved that at whatever peril, at whatever cost, the union of the states should be preserved. A patriot himself, his faith was strong and unwavering in the patriotism of his countrymen. Timid men said before Mr. Lincoln's inauguration, that we had seen the last president of the United States. A voice in influential quarters said, 'Let the union slide.' Some said that a union maintained by the sword was worthless. Others said a rebellion of eight million cannot be suppressed; but in the midst of all this tumult and timidity, and against all this, Abraham Lincoln was clear in his duty, and had an oath in heaven. He calmly and bravely heard the voice of doubt and fear all around him; but he had an oath in heaven, and there was not power enough on earth to make this honest boatman, backwoodsman, and broad-handed splitter of 
rails evade or violate that sacred oath. He had not been schooled in the ethics of slavery; his plain life had favored his love of truth. He had not been taught that treason and perjury were the proof of honor and honesty. His moral training was against his saying one thing when he meant another. The trust which Abraham Lincoln had in himself and in the people was surprising and grand, but it was also enlightened and well founded. He knew the American people better than they knew themselves, and his truth was based upon this knowledge.

"Fellow-citizens, the fourteenth day of April, I 865 , of which this is the eleventh anniversary, is now and will ever remain a memorable day in the annals of this republic. It was on the evening of this day, while a fierce and sanguinary rebellion was in the last stages of its desolating power; while its armies were broken and scattered before the invincible armies of Grant and Sherman; while a great nation, torn and rent by war, was already beginning to raise to the skies loud anthems of joy at the dawn of peace, it was startled, amazed, and overwhelmed by the crowning crime of slavery-the assassination of Abraham Lincoln. It was a new crime, a pure act of malice. No purpose of the rebellion was to be served by it. It was the simple gratification of a hell-black spirit of revenge. But it has done good, after all. 
It has filled the country with a deeper abhorrence of slavery and a deeper love for the great liberator. "Had Abraham Lincoln died from any of the numerous ills to which flesh is heir; had he reached that good old age of which his vigorous constitution and his temperate habits gave promise; had he been permitted to see the end of his great work; had the solemn curtain of death come down but gradually-we should still have been smitten with a heavy grief, and treasured his name lovingly. But, dying as he did die, by the red hand of violence, killed, assassinated, taken off without warning, not because of personal hate-for no man who knew Abraham Lincoln could hate him-but because of his fidelity to union and liberty, he is doubly dear to us, and his memory will be precious forever.

"Fellow-citizens, I end as I began, with congratulations. We have done a good work for our race to-day. In doing honor to the memory of our friend and liberator, we have been doing highest honors to ourselves and those who come after us; we have been fastening ourselves to a name and fame imperishable and immortal; we have also been defending ourselves from a blighting scandal. When now it shall be said that the colored man is soulless, that he has no appreciation of benefits or benefactors; when the foul reproach of ingratitude is hurled at us, and it is 
attempted to scourge us beyond the range of human brotherhood, we may calmly point to the monument we have this day erected to the memory of Abraham Lincoln."

An cminent divine at the unveiling of the monument here referred to, after congratulating: the orator of the clay upon his masterly portrayal of the character of the martyr president, turned to General Grant, who was present, and said: "There is but one Frederick Douglass."

On the anniversary celebration of the emancipation of slaves in the District of Columbia, $\mathrm{Mr}$. I) ouglass was the orator in the years $188_{3}, 188_{5}$, and 1886 , respectively. The speeches delivered at the time here referred to, are discourses on the relations subsisting between the white and colored people of the United States, in which the orator clearly shows that, though the negro possesses personal freedom and the ballot, he is still a victim of prejudice and injustice.

Here is an extract from the first of these addresses, delivered in the First Congregational Church, April I6, is $88_{3}$.

"Let any man now claim for the negro, or, worse still, let the negro now claim for himself, any right, privilege, or immunity which has hitherto been denied by law or custom, and he will at once open a fountain of bitterness, and call forth overwhelming wrath. 
"It is his sad lot to live in a land where all presumptions are arrayed against him, unless we except the presumption of inferiority and worthlessness. If his course is downward, he meets very little resistance, but if upward, his way is disputed at every turn of the road. If he comes in rags and in wretchedness, he answers the public demand for a negro, and provokes no anger, though he may provoke derision, but if he presumes to be a gentleman and a scholar, he is then entirely out of his place. He excites resentment and calls forth stern and bitter opposition. If he offers himself to a builder as a mechanic, to a client as a lawyer, to a patient as a physician, to a university as a professor, or to a department as a clerk, no matter what may be his ability or his attainments, there is a presumption, based upon his color or his previous condition, of incompetency, and if he succeeds at all, he has to do so against this most discouraging presumption.

"It is a real calamity, in this country, for any man, guilty or not guilty, to be accused of crime, but it is an incomparably greater calamity for any colored man to be so accused. Justice is often painted with bandaged eyes. She is described in forensic eloquence, as utterly blind to wealth or poverty, high or low, white or black; but a mask of iron, however thick, could never blind American justice, when a black man happens to be on 
trial. Here, even more than elsewhere, he will find all presumptions of law and evidence against him. It is not so much the business of his enemies to prove him guilty, as it is the business of himself to prove his innocence. The reasonable doubt which is usually interposed to save the life and liberty of a white man charged with crime, seldom has any force or effect when a colored man is accused of crime. Indeed, color is a far better protection to the white criminal, than anything else. In certain parts of our country, when any white man wishes to commit a heinous offense, he wisely resorts to burnt cork and blackens his face, and goes forth under the similitude of a negro. When the deed is done, a little soap and water destroys his identity, and he goes unwhipped of justice. Some negro is at once suspected and brought before the victim of wrong for identification, and there is never much trouble here, for as in the eyes of many white people all negroes look alike, and as the man who was arrested and who sits in the dock in irons is black, he is undoubtedly the criminal.

"A still greater misfortune to the negro is that the press, that engine of omnipotent power, usually tries him in advance of the courts, and, when once his case is lecided in the newspapers, it is easy for the jury to bring in its verdict of 'guilty as inclicted.' 
"In many parts of our common country, the action of courts and juries is entirely too slow for the impetuosity of the people's justice. When the black man is accused, the mob takes the law into its own hands, and whips, shoots, stabs, hangs, or burns the accused, simply upon the allegation or suspicion of crime. Of such proceedings Southern papers are full. A crime almost unknown to the colored man in the time of slavery seems now, from report, the most common. I do not believe these reports. There are too many reasons for trumping up such charges.

"Another feature of the situation is, that this mob violence is seldom rebuked by the press and the pulpit, in its immediate neighborhood, because the public opinion which sustains and makes possible such outrages, intimidates both press and pulpit.

"Besides, nobody expects that those who participate in such mob violence will ever be held answerable to the law, and punished. Of course, judges are not always unjust, nor juries always partial in cases of this class, but I affirm that I have here given you no picture of the fancy, and I have alleged no point incapable of proof, and drawn no line darker or denser than the terrible reality. The situation is discouraging, but, with all its hardships and horrors, I am neither desperate nor despairing as to the future." 
In the following extract from his second address delivered at the Lincoln Memorial Church, April 16, I895, he compliments President Clcveland upon his inaugural address and expresses the hope that he will administer the affairs of the government with due regard to the rights of all citizens irrespective of race or color.

These are his words:

No better words have dropped from the east portico of the Capitol since the inauguration days of Abraham Lincoln and General Grant. I believe they were sincerely spoken, but whether the president will be able to administer the government in the light of those liberal sentiments is an open question. The one-man power in our government is very great, but the power of party may be greater. The president is not the autocrat but the executive of the nation. But, happily, the executive is yet a power, and may be able to obtain the support of the co-ordinate branches of the government in so plain a duty as protecting the rights of the colored citizens, with those of all other citizens of the republic. For one, though Republican I am, and have been, and ever expect to be, though I did what I could to elect James G. Blaine as president of the United States, I am disposed to trust President Cleveland. By his words, as well as by his oath of office, solemnly subscribed to before uncounted thousands of 
American citizens, he is held and firmly bound to execute the constitution of the United States in the fullness of its spirit and in the completeness of its letter, and thus far he has shown no disposition to shrink from that duty.

"The Southern question is evidently the most difficult question with which President Cleveland will have to deal. Hard as it may be to manage his party on the civil service question, where he has only to deal with hungry and thirsty office seekers, nineteen out of every twenty of whom he must necessarily offend by failing to find desirable places for them, he will find it incomparably harder to meet that party's wishes in dealing with the Southern question. There are several methods of disposing of this Southern question open to him, and there are lions in the way, whichever method he may adopt.

"First, he may adopt a policy of total indifference. He may shut his eyes to the fact that in all of the Gulf states political rights of colored citizens are literally stamped out; that the constitution which he has solemnly sworn to support and enforce is under the feet of the mob; that in those states there is no such thing as a fair election and an honest count. He may utterly refuse to interfere by word or deed for the enforcement of the constitution and for the protection of the ballot, and let the Southern question drift whither- 
soever it will, to a port of safety or to a rock of disaster. He will probably be counseled to pursue the course of President Hayes, but I hope he will refuse to follow it. The reasons which supported that policy do not exist in the case of a Democratic president. Mr. Hayes made a virtue of necessity. He had fair warning that not a dollar or a dime would be voted by a Democratic Congress if the army were kept in the South. The cry of the country was against what was called bayonet rule.

"Secondly, the president may pursue a temporizing policy; keep the word of promise to the ear and break it to the heart, a half-hearted, a neither hot nor cold, a good Lord and a good devil policy. He may seek to avoid giving offense to any, and thus succeed in pleasing none; a policy which no man or party can pursue without inviting and earning the scorn and contempt of all honest men, and of all honest parties.

"'Thirdly, he may decide to accept the Mississippi plan of conducting elections at the South; encourage violence and crime; elevate to office the men whose hands are reddest with innocent blood; force the negroes out of Southern politics by the shotgun and the bulldozer's whip; cheat them out of the elective franchise; suppress the Republican vote; kill off their white leaders, and keep the South solid; and keep its one hundred 
and fifty-three electoral votes-obtained thus by force, fraud, and red-handed violence-ready to be cast for a Democratic candidate in $\mathrm{r} 888$. This might be acceptable to a certain class of Democrats at the South, but the Democrats at the North would abhor and denounce it as a bloody and hell-black policy. It would hurl the party from power in spite of the solid South, and keep it out of power another four and twenty years.

"Fourthly, he may sustain a policy of absolute fidelity to all the requirements of the constitution as it is, and, as John Adams said of the Declaration of Independence, he may bravely say to the South and to the nation: "Sink or swim, survive or perish, I am for the constitution in all its parts! I will be true to my oath, and I will, to the best of my ability, and to the fullest extent of my power, defend, protect, and maintain the rights of all citizens, without respect to race or color.'

"There can be no doubt as to which of these methods of treating the Southern question is the most honest and safe one. There may be many wrong ways for individuals or nations to pursue, but there is but one right way, and it remains to be seen if this is the one the present administration will adopt and pursue. Left to the promptings of his own heart and his own view of his constitutional duties, and to his own sense of the requirements of consistency and even expediency, 
I firmly believe that President Cleveland would do his utmost to protect and defend the constitutional rights of all classes of citizens. But he is not left to himself, and may adopt a different policy.

"One thing seems plain, which it is well for all parties to know and consider. It is this: There are seven million of colored citizens now in this republic. They stand between the two great parties-the Republican party and the Democratic party - and whichever of these two parties shall be most just and true to these seven million may safely count upon a long lease of power in this republic. It is not their votes alone that will tell. There is deep down among the people of this country a love of justice and fair play, and that fact will tell. It is now as it was in the time of war, and it will be so in all time. The party which takes the negro on its side will triumph. The world moves, and the conditions of success and failure have changed."

At another place in the same address, he boldly and truthfully assigns as the chief reason which caused the defeat of the Republican party in the presidential campaign of $\mathrm{I} 88_{4}$, the subordination of the principle of protection to the rights of citizens in the issues presented to the country.

The words to which we refer are as follows:-

"The great mistake made by the leaders of the Republican party during the late canvass was the 
failure to recognize the facts now stated, and their refusal to act upon them. They had become tired of the old issues and wanted now ones. They made their appeal to the pocket of the nation, and not to the heart of the nation. They attended to the mint, anise, and cummin of politics, but omitted the weightier matters of the law -judgment, mercy, and faith. They were loud for the protection of things, but silent for the protection of men. These things thcy ought to have done, and not to have left the other undone.

" The idea that righteousness exalteth a nation, and that $\sin$ is a reproach to any people, was, for a time, lost sight of. The all engrossing thought of the campaign was a judicious, discriminating, protective tariff. The great thing was protection to the wool of Ohio; to the iron of Pennsylvania, and to American manufacturers generally. Little was said, thought, or felt about national integrity, the importance of maintaining good faith with the freedmen or the Indian, or the protection of the constitutional rights of American citizens, except where such rights were in no danger.

"The great thing to be protected was American industry against competition with the pauper labor of Europe-not protection of the starving labor of the South. The body of the nation was everything; the soul of the nation was nothing. It did not appear from the campaign speeches 
that it was important to protect and preserve both, or that the body was not more dependent upon bread for life than was the soul dependent upon truth, justice, benevolence, and good faith for health and life. In the absence of these, the soul of the nation starves, sickens, and dies. It may not fall at once upon the withdrawal of these, but persistent injustice will, in the end, do its certain work of moral clestruction. No nation, no party, no man, can live long and flourish on falsehood, deceit, injustice, and broken pledges. Loyalty will perish where protection and good faith are denied and withheld, and nothing other than this should be expected, either by a party, a man, or by a government. On the other hand, where good faith is maintained, where justice is upheld, where truth and right prevail, the government will be like the wise man's house in scripture-the winds may blow, the rains may descend, the floods may come and beat upon it, but it will stand, because it is founded upon the solid rock of principle. I speak this, not only for the Republican party, but for all parties. Though I am a party man, to me parties are valuable only as they subserve the ends of good government. When they persistently violate the fundamental rights of the humblest and weakest in the land I scout them, despise them, and leave them."

The third address was delivered in the Israel 
Methodist Church, April I6, I886. The orator speaks of the rapid growth of Washington under freedom, and in the following passage vividly pictures what it would have become, if slavery had continued:-

"Fellow-citizens, we are proud to-day, and justly proud, of the prosperity and the increasing liberality of Washington. With all our fellow-citizens we behold it with pride and pleasure rising and spreading noiselessly around us, almost like the temple of Solomon, without the sound of a hammer. New faces meet us at the corners of the streets and greet us in the market places. Conveniences and improvements are multiplying on every hand. We walk in the shade of its beautiful trees by day, and in the rays of its soft electric lights by night. We make it warm where it is cool, and cool where it is warm, and healthy where it is noxious. Our magnificence fills the stranger and sojourner with admiration and wonder. The contrast between the old time of slavery and the new dispensation of liberty looms upon us on every hand. We feel it in the very air we breathe, and in the friendly aspect of all around us. But time would fail to tell of the vast and wonderful advancement in civilization made in this city by the abolition of slavery.

Perhaps a better idea could be formed of what has been done for Washington and for us by 
imagining what would be the case in a return to the old condition of things. Imagine the wheels of progress reversed; imagine that by some strange and mysterious freak of fortune slavery, with all its horrid concomitants, was revived; imagine that under the dome of yonder Capitol legislation was carried on, as formerly, by men with pistols in their belts and bullets in their pockets; imagine the right of speech denied, the right of petition stamped out, the press of the District muzzled, and a word in the streets against slavery the sign for a mob; imagine a lone woman like Miss Myrtilla Miner, having to defend her right to teach colored girls to read and write, with a pistol in her hand, here in this very city, now dotted all over with colored schools, which rival in magnificence the white schools of any other city of the Union; imagine this, and more, and ask yourselves the question: What progress has been made in liberty and civilization within the borders of this capital? Further on let us ask: Of what avail would be our cloud-capped towers, our gorgeous palaces, and our solemn temples if slavery agrain held sway here? Of what avail would be our marble halls if once more they resounded with the crack of the slave whip, the clank of the fetter, and the rattle of chains; if slave auctions were held in front of the halls of justice, and chaingangs were marched over Pennsylvania avenue to 


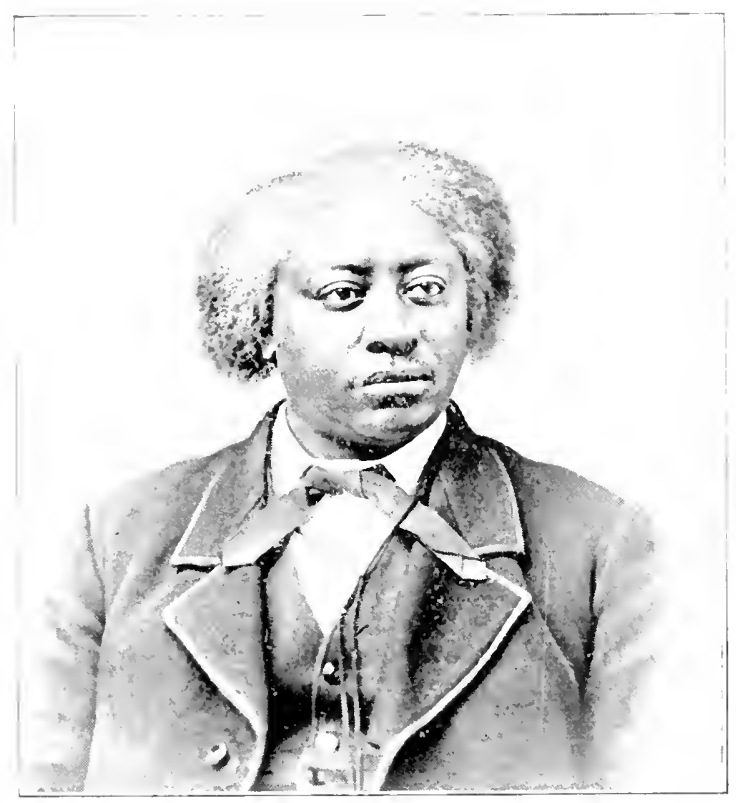

FREDERICK DOE'GLASS, IR. 

the Long Bridge, for the New Orleans market? Of what avail would be our state dinners, our splendid receptions, if, like Babylon of old, our people were making merchandise of God's image, trafficking in human blood and in the souls and bodies of men? Were this District once more covered with this moral blight and mildew, you would hear of no plans, as now, for celebrating within its borders the centennial anniversary of the adoption of the constitution of the United States. Bold and audacious as were the advocates of slavery in the olden time, they would have been ashamed to invite here the representatives of the civilized world to inspect the workings of their slave system. To have done so would have been like inviting a clean man to touch pitch, a humane man to witness an execution, a tenderhearted woman to witness a slaughter. In its boldest days slavery drew in its claws and presented a velvet paw to strangers. They knew it was like Lord Granby's character, which could only pass without reprobation as it passed without observation. Emancipation liberated the master as well as the slave. The fact that our citizens are now loudly proclaiming Washington to be the right place for the celebration of the discovery of the continent by Columbus, and the adoption of the constitution of the United States, is an acknowledgment of and attestation of the higher 10 
civilization that has, in their judgment, come here with the abolition of slavery. They no longer dread the gaze of civilized men. They no longer fear lest a word of liberty should fall into the ear of a trembling captive and awaken his manhood. They are no longer required to defend with their lips what they must have condemned in their hearts. When the galling chain dropped from the limbs of the slave, the mantle of shame dropped from the brows of their masters. The emancipation of the one was the deliverance of the other; so that this day, in fact, belongs to the one as truly as it belongs to the other, though it is left to us alone to keep it in memory."

The largest and most representative convention of colored men ever held in the United States was held in Liederkranz Hall, Louisville, Kentucky, September 25-27, I883. It was, in fact, their first real national convention. There were in attendance nearly three hundred delegates from twenty-eight states. Mr. Douglass was chosen permanent president and addressed the convention. His speech on this occasion, for sound reasoning and eloquence of expression, is not surpassed by the most distinguished orators of our time.

The Louisville Courier-Journal, one of the best known Democratic newspapers in the country, in its issue of September 26, speaking of 
the convention and Mr. Douglass' great effort says:-

"The convention was called to order by Hon. Frederick Douglass, the permanent chairman, who called upon Dr. Arnett, of Nashville, to offer prayer. At its close, the New Orleans Jubilee Singers chanted the Lord's prayer in a most exquisite and impressive manner. The chairman then introduced Dr. K. Fitzbutler, who delivered an address of welcome to the delegates. His remarks were well put and were received with applause.

"Mr. Douglass then began his address in a subdued tone of voice, but as he warmed up he grew louder and soon filled the hall with his utterances. Discovering in the audience Hon. James Speed, President Lincoln's last attorney-general, and Gen. James A. Ekin, the speaker invited them to the stage, where they were seated on the left of the speaker. The hall was filling rapidly, and by the time Douglass began to infuse the audience with the inspiration that he felt, a large number of white citizens were seated in the hall. It was evident from the first that the convention expected something grand, and it is but the truth to say that they were not disappointed in Mr. Douglass. In the language of R. A. Jones, of Cleveland, Ohio, 'It was the grandest effort ever made by a colored American.' As he proceeded, he came to 
many places where he seemed to halt in his progress, and, in lofty flights of eloquence and logic, ascend to a plane never visited by speakers engaged in the discussion of the questions which he had taken up. It frequently became necessary for him to wait several moments for the enthusiasm to subside."

Here are a few passages from the Louisville speech:-

"Why are we here in this national convention? To this we answer, first, because there is a power in numbers and in union; because the many are more than the few; because the voice of a whole people, oppressed by a common injus. tice, is far more likely to command attention and exert an influence on the public mind, than the voice of single individuals and isolated organizations; because, coming together from all parts of the country, the members of a national convention have the means of a more comprehensive knowledge of the general situation, and may, therefore, fairly be presumed to conceive more clearly and express more fully and wisely the policy it may be necessary for them to pursue in the premises. Because conventions of the people are in themselves harmless, and when made the means of setting forth grievances, whether real or fancied, they are the safety-valves of the republic, a wise and safe substitute for violence, 
dynamite, and all sorts of revolutionary action against the peace and good order of society. If they are held without sufficient reason, that fact will be made manifest in their proceedings, and people will only smile at their weakness and pass on to their usual business without troubling themselves about the empty noise they are able to make. But if held with good cause and by wise, sober, and earnest men, that fact will be made apparent and the result will be salutary. That good old maxim, which has come down to us from revolutionary times, that error may be safely tolerated, while truth is left free to combat it, applies here. A bad law is all the sooner repealed by being executed, and error is sooner dispelled by exposure than by silence. So much we have deemed it fit to say of conventions generally, because our resort to this measure has been treated by many as if there were something radically wrong in the very idea of a convention. It has been treated as if it were some ghastly, secret conclave, sitting in darkness to devise strife and mischief. The fact is, the only serious feature in the argument against us is the one which respects color. We are asked not only why hold a convention, but, with emphasis, why hold a colored convention? Why keep up this odious distinction between citizens of a common country and thus give countenance to the color line? It is 
argued that, if colored men hold conventions based upon color, white men may hold white conventions based upon color, and thus keep open the chasm between one and the other class of citizens, and keep alive a prejudice which we profess to deplore. IVe state the argument against us fairly and forcibly, and will answer it candidly and, we hope, conclusively. By that answer it will be seen that the force of the objection is, after all, more in sound than in substance. No reasonable man will ever object to white men holding conventions in their own interests, when they are once in our condition and we in theirs, when they are the oppressed and we the oppressors. In point of fact, however, white men are already in convention against us in various ways and at many important points. The practical construction of American life is a convention against us. Human law may know no distinction among men in respect of rights, but human practice may. Examples are painfully abundant.

\section{"Civil, Righits.}

"The right of every American citizen to select his own society, and invite whom he will to his own parlor and table, should be sacredly respected. A man's house is his castle, and he has a right to admit or refuse admission to it as he may please, and defend his house from all in- 
truders even with force, if need be. This right belongs to the humblest not less than the highest, and the exercise of it by any of our citizens toward any person or class who may presume to intrude, should cause no complaint, for each and all may exercise the same right toward whom he will.

"When he quits his home and goes upon the public street, enters a public car or a public house, he has no exclusive right of occupancy. He is only a part of the great public, and while he has the right to walk, ride, and be accommodated with food and shelter in a public conveyance or hotel, he has no exclusive right to say that another citizen, tall or short, black or white, shall not have the same civil treatment with himself. The argument against equal rights at hotels is very improperly put upon the ground that the exercise of such rights is social equality. But this ground is unreasonable. It is hard to say what social equality is, but it is certain that going into the same street car, hotel, or steamboat cabin, does not make any man society for another any more than flying in the same air makes all birds of one feather.

"Two men may be seated at the same table at a hotel, one may be a Webster in intellect, and the other a Guiteau in feebleness of mind and morals, and, of course, socially and intellectually 
they are as wide apart as are the poles of the moral universe, but their civil rights are the same. The distinction between the two sorts of equality is broad and plain to the understanding of the most limited, and yet, blinded by prejudice, men never cease to confound one with the other, and allow themselves to infringe the civil rights of their fellow-citizens, as if those rights were in some way in violation of their social rights.

"That this denial of rights to us is because of our color, only as color is a badge of condition, is manifest in the fact that no matter how decently dressed or well-behaved a colored man may be, he is denied civil treatment in the ways thus pointed out, unless he comes as a servant. His color, not his character, determines the place he shall hold and the kind of treatment he shall receive. That this is due to a prejudice and has no rational principle under it, is seen in the fact that the presence of colored persons in hotels and rail cars is only offensive when they are there as guests and passengers. As servants they are welcome, but as equal citizens they are not. It is also seen in the further fact that nowhere else on the globe, except in the United States, are colored people subject to insult and outrage on account of color. The colored traveler in Europe does not meet it, and we denounce it here as a disgrace to American civilization and American religion and as a 
violation of the spirit and letter of the constitution of the United States. From those courts which have solemnly sworn to support the constitution, and that yet treat this provision of it with contempt, we appeal to the people, and call upon our friends to remember our civil rights at the ballot-box. On the point of the two equalities we are determined to be understood.

"We leave social equality where it should be left, with each individual man and woman. No law can regulate or control it. It is a matter with which governments have nothing whatever to do. Each may choose his own friends and associates without interference or dictation of any.

\section{"Political Equality.}

"Flagrant as have been the outrages committed upon colored citizens in respect to their civil rights, more flagrant, shocking, and scandalous still have been the outrages committed upon our political rights, by means of bulldozing and Kukluxing, Mississippi plans, fraudulent counts, tissue ballots, and the like devices. Three states in which the colored people outnumber the white population are without colored representation, and their political voice suppressed. The colored citizens in those states are virtually disfranchised, the constitution held in utter contempt, and its provisions nullified. This has been 
done in the face of the Republican party and successive Republican administrations.

"It was once said by the great O'Connell that the history of Ireland might be traced like a wounded man through a crowd by the blood, and the same may be truly said of the history of the colored voters of the South.

"They have marched to the ballot-box in face of gleaming weapons, wounds, and death. They have been abandoned by the government and left to the laws of nature. So far as they are concerned, there is no government or constitution of the United States. They are under control of a foul, haggard, and damning conspiracy against reason, law, and constitution. How you can be indifferent, how any leading colored men can allow themselves to be silent in presence of this state of things, we cannot see.

". Should tongues be mute while deeds are wrought

Which well might shame extremest hell ?'

And yet they are mute, and condemn our assembling here to speak out in manly tones against the continuance of this infernal reign of terror.

"This is no question of party. It is a question of law and government. It is a question whether men shall be protected by law or be left to the mercy of cyclones of anarchy and bloodshed. It is whether the government or the mob shall rule this land; whether the promises solemnly made 
to us in the constitution be manfully kept or meanly and flagrantly broken. Upon this vital point we ask the whole people of the United States to take notice that whatever of political power we have shall be exerted for no man of any party who will not in advance of election promise to use every power given him by the government, state or national, to make the black man's path to the ballot-box as straight, smooth, and safe as that of any other American citizen.

\section{"Political Ambition.}

"We are as a people often reproached with ambition for political offices and honors. We are not ashamed of this alleged ambition. Our destitution of such ambition would be our real shame. If the six millions and a half of people whom we represent could develop no aspirants to political office and honor under this government, their mental indifference, barrenness, and stolidity might well enough be taken as proof of their unfitness for American citizenship.

"It is no crime to seek or hold office. If it were it would take a larger space than that of Noah's ark to hold the white criminals.

"One of the charges against this convention is that it seeks for the colored people a larger share than they now possess in the offices and emoluments of the government. 
"We are now significantly reminded by even one of our own members that we are only twenty years out of slavery, and we ought therefore to be modest in our aspirations. Such leaders should remember that men will not be religious when the devil turns preacher.

"The inveterate and persistent office-seeker and officc-holder should be modest when he preaches that virtue to others which he does not himself practice. Wolsey could not tell Cromwell to fling away ambition properly only when he had flung away his own.

" We are far from affirming that there may not be too much zeal among colored men in pursuit of political preferment; but the fault is not wholly theirs. They have young men among them noble and true, who are educated and intelligent-fit to engage in enterprise of 'pith and moment'-who find themselves shut out from nearly all the avenues of wealth and respectability, and hence they turn their attention to politics. They do so because they can find nothing clsc. The best cure for the evil is to throw open other avenues and activities to them.

"We shall never cease to be a despised and persecuted class while we are known to be excluded by our color from all important positions under the government.

"While we do not make office the one thing im- 
portant, nor the one condition of our alliance with any party, and hold that the welfare, prosperity, and happiness of our whole country is the true criterion of political action for ourselves and for all men, we cannot disguise from ourselves the fact that our persistent exclusion from office as a class is a great wrong, fraught with injury, and ought to be resented and opposed by all reasonable and effective means in our power.

"We hold it to be self-evident that no class or color should be the exclusive rulers of this country. If there is such a ruling class, there must of course be a subject class, and when this condition is once established this government of the people, by the people, and for the people will have perished from the earth."

In the city of Washington, D. C., October 22, I 883 , a vast number of citizens assembled in Lincoln hall to give expression to their views concerning the recent decision of the Supreme Court of the United States, in which it is held that the Civil Rights Act is unconstitutional. Addresses were delivered by Hon. Frederick Douglass, Col. Robert G. Ingersoll, Judge Samuel Shellabarger, and Rev. J. E. Rankin, D.D.

The National Republican the next morning in its comment upon the meeting, said: "In all its history Lincoln hall was never so crowded as last night. There was no standing room-there was 
scarcely even breathing room. Stage and floor were alike crowded. There were over two thousand persons inside the doors, and double that number turned reluctantly away after finding it impossible to get in. In point of numbers it was the largest meeting ever gathered in a Washington hall. The occasion was as equally remarkable as the attendance in bringing together all the most prominent colored citizens of the district, as well as many distinguished whites. All the famous leaders of the race were present-Frederick Douglass, Blanche Bruce, Richard T. Greener, John F. Cook, Rev. Francis Grimké, and others. Present with them were such white representatives as Col. R. G. Ingersoll, Rev. J. E. Rankin, Judge Shellabarger, President Patton of Howard University, and others equally famous for their efforts in the religious and political world in behalf of equal rights and justice. Hundreds of white ladies were seated on the stage and in the audience.

"A few of those on the stage were Judge Lawrence, A. M. Clapp, Judge Shellabarger, M. M. Holland, Rev. G. W. Noore, Perry Carson, Collector Cook, Rev. Francis Grimké, Prof. Gregory, Frederick Douglass, Jr., L. H. Douglass, Rev. A. W. Upshaw, Rev. William Waring, Dr. O. M. Atwood, Dr. Francis, Calvin Chase, Mrs. Belva Lockwood, President W. W. Patton of Howard University, Prof. Wiley Lane." 
Prof. J. M. Gregory presided, and in introducing Hon. Frederick Douglass, said :-

"It is our good fortune to have with us one who needs no extended introduction to an American audience; a man whose fame, not confined to the borders of his own country, has gone throughout the civilized world, and whose utterances at the late Louisville convention, fresh in the minds of all, were compared by the press of the country with the great speeches of England's statesmen, John Bright and William Gladstone. This eminent man, whom it is my privilege to introduce, is the acknowledged leader of the negro race in America, and that people look to him, more than to any other, for advice and guidance at this particular crisis in their history. The Honorable Frederick Douglass will now address you."

Mr. Douglass came forward amid deafening applause and delivered one of the ablest speeches of his life. We quote a few passages to show his style of vehement eloquence and invective, and to give some idea of his exhaustive argument.

" The cause which has brought us here to-night is neither common nor trivial. Few events in our national history have surpassed it in magnitude, importance, and significance. It has swept over the land like a moral cyclone, leaving moral desolation in its track.

"We feel it as we felt the furious attempt, 
years ago, to force the accursed system of slavery upon the soil of Kansas, the enactment of the lugitive Slave Bill, the repeal of the Missouri Compromise, the Dred Scott decision. I look upon it as one more shocking development of that moral weakness in high places which has attended the conflict between the spirit of liberty and the spirit of slavery from the beginning, and I venture to predict that it will be so regarded by after-coming generations.

"Far down the agges, when men shall wish to inform themselves as to the real state of liberty, law, religion, and civilization in the United States at this juncture of our history, they will overhaul the proceedings of the Supreme Court, and read the decision declaring the Civil Rights Bill unconstitutional and void.

"From this they will learn more than from many volumes, how far we have advanced, in this year of grace, from barbarism toward civilization.

"Fellow-citizens, among the great evils which now stalk abroad in our land, the one, I think, which most threatens to undermine and destroy the foundations of our free institutions is the great and apparently increasing want of respect entertained for those to whom are committed the responsibility and the duty of administering our government. On this point I think all good men must agree, and against this evil I trust you feel, 
and we all feel, the deepest repugnance, and that we will, neither here nor elsewhere, give it the least breath of sympathy or encouragement. We should never forget, that whatever may be the incidental mistakes or misconduct of rulers, government is better than anarchy, and patient reform is better than violent revolution.

"But while I would increase this feeling, and give it the emphasis of a voice from heaven, it must not be allowed to interfere with free speech, honest expression, and fair criticism. To give up this would be to give up liberty, to give up progress, and to consign the nation to moral stagnation, putrefaction, and death.

"In the matter of respect for dignitaries, it should never be forgotten, however, that duties are reciprocal, and while the people should frown down every manifestation of levity and contempt for those in power, it is the duty of the possessors of power so to use it as to deserve and insure respect and reverence.

"To come a little nearer to the case now before us. The Supreme Court of the United States, in the exercise of its high and vast constitutional power, has suddenly and unexpectedly decided that the law, intended to secure to colored people the civil rights guaranteed to them by the following provision of the constitution of the United States, is unconstitutional and void. Here it is :- 
“' No state,' says the fourteenth amendment, 'shall make or enforce any law which shall abridge the privileges or immunities of citizens of the United States; nor shall any state deprive any person of life, liberty, or property, without due process of law; nor deny any person within its jurisdiction the equal protection of the laws.'

"Now, when a bill has been discussed for weeks and months, and even years, in the press and on the platform, in Congress and out of Congress; when it has been calmly debated by the clearest heads, and the most skillful and learned lawyers in the land; when every argument against it has been over and over again carefully considered and fairly answered; when its constitutionality has been especially discussed, pro and con; when it has passed the United State House of Representatives, and has been solemnly enacted by the United States Senate, perhaps the most imposing legislative body in the world; when such a bill has been submitted to the cabinet of the nation, composed of the ablest men in the land; when it has passed under the scrutinizing eye of the attorney-general of the United States; when the executive of the nation has given to it his name and formal approval; when it has taken its place upon the statute book, and has remained there for nearly a decade, and the country has largely assented to it, you will agree with me that the 


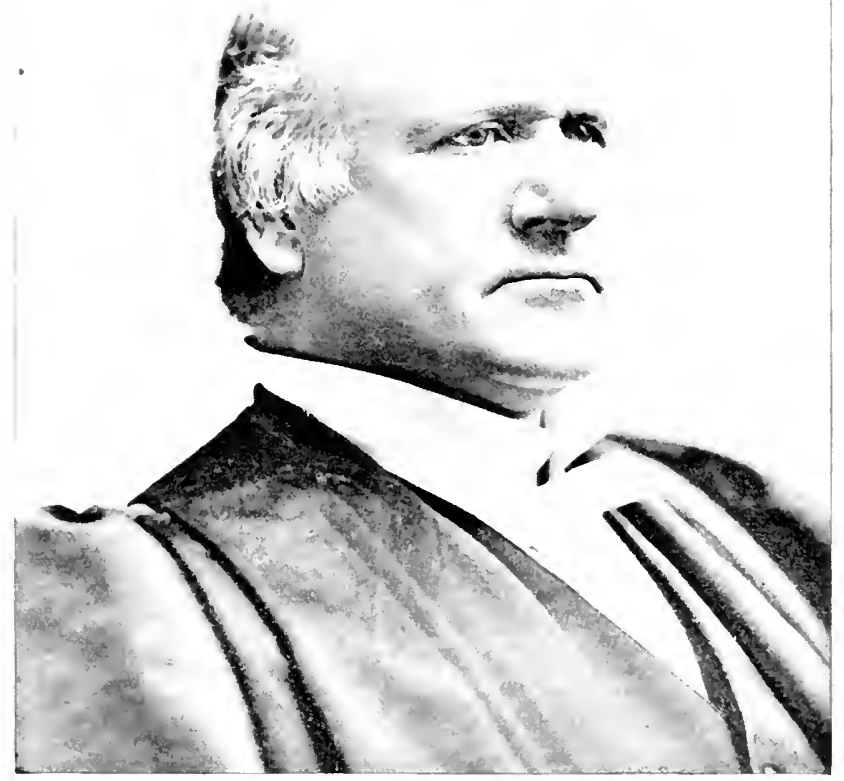

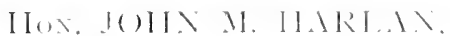

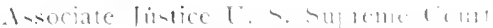

Justice Harlan dissented from his colleague in the Civil kights Bill decision, by upholding its constitutionality. 

rea ons for declaring such a law unconstitutional and void should be strong, irresistible, and absolutely conclusive.

"Inasmuch as the law in question is a law in favor of liberty and justice, it ought to have had the benefit of any doubt which could arise as to its strict constitutionality. This, I believe, will be the view taken of it, not only by laymen like myself, but by eminent lawyers as well."

* * * * * * * * *

"Color prejudice is not the only prejudice against which a republic like ours should guard. The spirit of caste is dangerous everywhere. There is the prejudice of the rich against the poor, the pride and prejudice of the idle dandy against the hard handed working man. There is, worst of all, religious prejudice; a prejudice which has stained a whole continent with blood. It is, in fact, a spirit infernal, against which every enlightened man should wage perpetual war. Perhaps no class of our fellow-citizens has carried this prejudice against color to a point more extreme and dangerous than have our Catholic Irish fellow-citizens, and yet no people on the face of the earth have been more relentlessly persecuted and oppressed on account of race and religion, than the Irish people.

"But in Ireland, persecution has at last reached a point where it reacts terribly upon her persecu- 
tors. England to-day is reaping the bitter consequences of her injustice and oppression. Ask any man of intelligence to-day, "What is the chief source of England's weakness?' 'What has reduced her to the rank of a second-class power?' and the answer will be 'Ireland!' Poor, ragged, hungry, starving, and oppressed as she is, she is strong enough to be a standing menace to the power and glory of England.

"Fellow-citizens! we want no black Ireland in America. We want no aggrieved class in America. Strong as we are without the negro, we are stronger with him than without him. The power and friendship of seven millions of people scattered all over the country, however humble, are not to be despised.

"To-day, our republic sits as a queen among the nations of the earth. Peace is within her walls and plenteousness within her palaces, but he is a bolder and a far more hopeful man than I am, who will affirm that this peace and prosperity will always last. History repeats itself. What has happened once may happen again.

"The negro, in the Revolution, fought for us and with us. In the war of 1812 General Jackson, at New Orleans, found it necessary to call upon the colored people to assist in its defense against England. Abraham Lincoln found it necessary to call upon the negro to defend the 
Union against rebellion, and the negro responded gallantly in all cases.

"Our legislators, our presidents, and our judges should have a care, lest, by forcing these people outside of law, they destroy that love of country which is needful to the nation's defense in the day of trouble. I am not here, in this presence, to discuss the constitutionality or unconstitutionality of this decision of the Supreme Court. The decision may or may not be constitutional. That is a question for lawyers, and not for laymen, and there are lawyers on this platform as learned, able, and eloquent as any who have appeared in this case before the Supreme Court, or as any in the land. To these I leave the exposition of the constitution; but I claim the right to remark upon a strange and glaring inconsistency with former decisions, in the action of the court on this Civil Rights Bill. It is a new departure, entirely out of the line of the precedents and decisions of the Supreme Court at other times and in other directions where the rights of colored men were concerned. It has utterly ignored and rejected the force and application of object and intention as a rule of interpretation. It has construed the constitution in defiant disregard of what was the object and intention of the adoption of the fourteenth amendment. It has made no account whatever of the intention and purpose of Con- 
gress and the president in putting the Civil Rights Bill upon the statute book of the nation. It has seen fit in this case, affecting a weak and much persecuted people, to be guided by the narrowest and most restricted rules of legal interpretation. It has viewed both the constitution and the law with a strict regard to their letter, but without any generous recognition of their broad and liberal spirit. Upon those narrow principles the decision is logical and legal, of course. But what I complain of, and what every lover of liberty in the United States has a right to complain of, is this sudden and causeless reversal of all the great rules of legal interpretation by which this court was governed in other days, in the construction of the constitution and of laws respecting colored people.

"In the dark days of slavery, this court, on all occasions, gave the greatest importance to intention as a guide to interpretation. The object and intention of the law, it was said, must prevail. Everything in favor of slavery and against the negro was settled by this object and intention. The constitution was construed according to its intention. We were over and over again referred to what the framers meant, and plain language was sacrificed that the so affirmed intention of these framers might be positively asserted. When we said in behalf of the negro that the constitu- 
tion of the United States was intended to establish justice and to secure the blessings of liberty to ourselves and our posterity, we were told that the words said so, but that that was obviously not its intention; that it was intended to apply only to white people, and that the intention must govern.

"When we came to that clause of the constitution which declares that the immigration or importation of such persons as any of the states may see fit to admit shall not be prohibited, and the friends of liberty declared that that provision of the constitution did not describe the slave trade, they were told that while its language applied not to slaves, but to persons, still the object and intention of that clause of the constitution was plainly to protect the slave trade, and that that intention was the law. When we came to that clause of the constitution which declares that ' No person held to service or labor in one state, under the laws thereof, escaping into another, shall in consequence of any law or regulation therein be discharged from such service or labor, but shall be delivered up on claim of the party to whom such service or labor may be due,' we insisted that it neither described nor applied to slaves; that it applied only to persons owing service and labor, that slaves dicl not and could not owe service and labor; that this clause of the 
constitution said nothing of slaves or the masters of slaves; that it was silent as to slave states or free states; that it was simply a provision to enforce a contract; to discharge an obligation between two persons capable of making a contract, and not to force any man into slavery, for the slave could not owe service or make a contract.

"We affirmed that it gave no warrant for what was called the 'Fugitive Slave Bill,' and we contended that that bill was therefore unconstitutional; but our arguments were laughed to scorn by that court. We were told that the intention of the constitution was to enable masters to recapture their slaves, and that the law of ninetythree and the Fugitive Slave Law of 1850 were constitutional.

"Fellow-citizens! while slavery was the base line of American society, while it ruled the church and the state, while it was the interpreter of our law and the exponent of our religion, it admitted no quibbling, no narrow rules of legal or scriptural interpretations of Bible or constitution. It sternly demanded its pound of flesh, no matter how much blood was shed in the taking of it. It was enough for it to be able to show the intention to get all it asked in the courts or out of the courts. But now slavery is abolished. Its reign was long, dark, and bloody. Liberty now is the 
base line of the republic. Liberty has supplanted slavery, but I fear it has not supplanted the spirit or power of slavery. Where slavery was strong, liberty is now weak.

"Oh, for a Supreme Court of the United States which shall be as true to the claims of humanity, as the Supreme Court formerly was to the demands of slavery! When that day comes, as come it will, a Civil Rights Bill will not be declared unconstitutionai and void, in utter and flagrant disregard of the objects and intentions of the national legislature by which it was enacted, and of the rights plainly secured by the constitution."

In Washington, D. C., in August of $\mathrm{r}_{85}$, a large audience assembled in the Nineteenth Street Baptist Church, to pay respect to the memory of the late General U. S. Grant. Hon. John M. Langston presided. Mr. Douglass was one of the speakers and paid a glowing tribute to the character of General Grant. In his beautiful peroration he concludes with the remark which doubtless would have been of prophetic import but for the sudden death of Mr. Conkling in I 888 . Here are a few extracts:-

"It is too early to give a complete analysis of this great man's character, or to state in full our debt of gratitude to him for his work in the world. But this may be said of him, for it will meet no 
contradiction from any quarter. He was a man too great to be envious of the fame of others; too just to detract from the merits of the most brilliant of his companions in arms; too enlightened to be influenced by popular prejudice; too humane to despise the humblest. In him the negro found a protector, the Indian a friend, a vanquished foe a brother, an imperiled nation a savior.

"He was accessible to all men, whether of high or low condition. He did not hide himself behind his dignity. The black soldier was welcome in his tent, the freedman in his house. To those who forbade them, he simply said, "Where I am, they may come!'

"Among all the American people, no class will feel the loss of his death more deeply than we. No people will hallow his name and cherish his memory more sacredly than we. To others he was a patriot; to us he was a liberator. To others he gave peace; to us he gave liberty. To others he saved a country; to us he gave a country. He found us slaves, and left us freemen. He found us aliens, and left us citizens. He found us outside of law and civilization, and made us a part of the American body politic.

"The statesman and orator who could best describe, if he were here, the character and services of U.S. Grant is now out of public life, traveling in a far country. Ye gods! how he loved him! 
How grandly and bravely he stood by the fallen hero in every hour of trial, and how firmly they believed and trusted each other. Who that witnessed it can ever forget the scene in the national convention, when the great senator from New York, in matchless eloquence, presented the name of the hero of Appomattox. The one was on the platform of debate, what the other was on the field of battle, and the vast audience was swayed to and fro by his eloquence, as the tall forest is swayed by the storm. The final funeral oration upon General Grant, the one which is to do full justice to his memory, the one that is to thrill the heart of the nation, and is to be read away down the tide of time by after-coming generations of the American people, must be delivered from the chamber of the American Senate by Roscoe Conkling."

The following passage occurs in his celebrated lecture "The Mission of the War," and we consider it one of the gems of the English language :-

"Ah! there was a time in our national history" when the colored man was not the despised man he has since become in the eyes of the American people! When rebel armies were in the field threatening the republic with destruction, when rebellion was assured, bold, defiant, and flushed with victory; when the country was rent asunder at the center, and a bloody chasm yawned before 
it; when the crowned heads of the old world were saying among themselves, aha! aha! the great republican bubble is about to burst and free government to vanish; when the loyal armies of the Union were melting away like the snows of winter under a summer sun; when every morning saw dead soldiers, at every northern railroad station, and stumps of men, maimed, mutilated, armless, and legless, confronted us at every corner; when churches, halls, and houses were draped with the weeds of mourning; when the very air was heavy with sorrow and aged eyes swam in young tears for the slain; when the hearts of strong men were failing them for fear of coming disaster; when the recruiting sergeants, with drum and fife, with banner and badge, foot sore and weary, were marching our streets from morning till night, calling for men, more men to go to the front, and fill up the gaps made by rebel powder and pestilence; when the fate of the republic trembled in the balance and the star-spangled banner drooped at its staff heavy with bloodAbraham Lincoln called, aye, the country in its extremity called, upon the colored man to reach out his iron arm and clutch with steel fingers that faltering flag, and he came, he came! full two hundred thousand strong, and from that hour the power of rebellion was broken and the tide of battle turned in favor of loyalty, liberty, and union." 


\section{CHAP'TER XI.}

Extracts from his Speeches and LecturesConcluded.

OnE of the early lectures prepared by $\mathrm{Mr}$. Douglass, after his anti-slavery lectures, was "Self-made Men." It was delivered in many parts of the country, and attracted wide attention. The following extract is taken from this lecture :-

"By self-made men I mean precisely what the phrase imparts to the popular mind. They are the men who, without the ordinary helps and favoring circumstances which usually distinguish and promote success, have risen, in one way or another, and attained knowledge, power, position, and fame in the world. They are the men who owe very little to birth, relationships, or friendly surroundings. They have neither had the advantage of wealth inherited, nor early training, nor approved means of education. Like the overtaxed Hebrew slaves of Egypt, they have been required to make bricks without straw. They are the men who have come up, not only without the voluntary aid and assistance of society, but often in open, direct, and derisive defiance of all the powers and efforts of society to obstruct, 
repress, and keep them down. In a world of schools, colleges, and other institutions of learning, they have been compelled to obtain education out of earth, air, and sky. In a peculiar sense they are indebted to themselves for themselves, and are architects of their own fortunes. If they have traveled far, they have made the road on which they traveled. If they have ascended high, they have built their own ladder. They are the men who come from fathomless social depths, and have burst the social strata that bound them. From the cornfield, the plow, and the work-bench, from the heartless pavements of large and crowded cities, barefooted, hungry, and friendless, out of the depths, obscurity, darkness, and destitution, they have come. Flung overboard in the midnight storm, on a perilous ocean, without oars, ropes, or life-preservers, they have bravely buffeted the frowning billows with their own sinewy arms, and have risen in safety, where other men, supplied with the best appliances, have fainted, despaired, and gone down. Such men as these, whether we find them in one position or another, whether in the college or in the factory, whether professors or plowmen, whether of Anglo-Saxon or Anglo-African origin, are self-made men, and have fairly won that title, and what honor soever that title implies. 
"Though a man of this class may not be worshiped as a hero, there is a genuine heroism in the struggle he has made, and sublimity and glory in the triumph. Every such example of success is a help to the race. It is an assertion of the latent powers of simple, unaided manhood, and affords encouragement to the least favored among men. It robs labor of pain. It dispels gloom from the brow of destitution, and makes the roughest and flintiest hardships in the stern battle of life seem trifles light as air."

After showing in what way self-made men attain success, he takes up certain criticisms to which men of this class are exposed. The passage here introduced from the same lecture, while it shows the high value which Mr. Douglass places upon education and institutions of learning, furnishes an illustration of the broad and liberal views entertained by him upon all great questions.

This is the passage to which we refer:-

"By these remarks, however, I intend no disparagement of educated men, or of educational institutions. In all my admiration of selfmade men, I am far from considering them the best-made men.

"The roundness, fullness, and symmetry which we find in the scholar are often missing in the self-made man. $\mathrm{He}$ is strong, but apt to be 
one-sided. The hot rays of the sun have tanned him, and the rugged road over which he has traveled has marred his feet. The world has a value for skill and power, and for polish and beauty as well. It was not alone the hard work and good sense of Horace Greeley and Abraham Lincoln that made them successful, but the thoroughly educated men whom they had the wisdom to call into their councils.

"So far from disparaging and underrating the importance of educational institutions, I am bound to say there never was a self-educated man in the world who, with the same exertion, would not have been better educated by the aid of schools.

"I admit that self-made men are apt to underrate the value of schools and colleges. It is a natural result of the means by which they have obtained knowledge. Having made their way without such help, they naturally think that others can as well do the same. They forget that their own success might have been vastly greater with the help of these institutions than without them. They also forget that most young people need the spur to exertion which these institutions are fitted to give.

"Another criticism upon self-made men is they are not over-modest. Like a great many others, they are apt to think more highly of 
themselves than they ought to think. Having fought the good fight and gained the victory, they credit themselves with their full value, and a trifle over. They know how to use the first personal pronoun, and do use it profusely. It cannot be said of them that they fail to assert themselves, or to claim their own achievements. Of this sort of self-made men Andrew Johnson was, perhaps, an exaggerated example.

"In apology for this weakness, it may be said that a man indebted to himself for himself cannot well help thinking pretty highly of himself. The energies employed, the obstacles overcome, the height he has attained, the contrast he presents to other men, force a sense of his own importance and make him egotistical."

In point of polish and finish, the lecture known as "William the Silent," in the judgment of many, will take first rank among the writings of Mr. Douglass. It thrilled and captured the audiences that heard it. The beautiful passage in which the lecturer draws a parallel between William of Nassau and Abraham Lincoln is here given :-

"William the Silent stands in some respects alone in history. He had to deal with a condition of things peculiar to his own age and country.

"What George Washington was in the darkest 
hours of American independence, what Toussaint L'Ouverture was to the black republic of Hayti, when the armies of Napoleon encamped about it and attempted its re-enslavement; what Abraham Lincoln was to this country when James Buchanan had surrendered it to rebels; what General Grant was in the Wilderness, 'Fighting it out on that line if it took all summer,'- that and more was William the Silent to his country, and to the cause of civil and religious liberty in the Netherlands.

"But of the illustrious men thus mentioned, the one who most resembled our hero, you will easily see, was Abraham Lincoln. In saying this, I say much for Abraham Lincoln, and for the American people, for he embodied more of the best elements of the American character and statesmanship than any of his long line of predecessors.

"In the matter of his social position and training, William stands in striking contrast to Abraham Lincoln. William was highborn, a prince of the blood, surrounded from the cradle with the best conditions that great wealth and high position could purchase. Lincoln, on the contrary, sprang from the lowest round of the social ladder, with nothing but his simple manhood to support him. There was also a marked differcnce in the respective mental characteristics of the two men. William was pre-eminently a 
leader of thought as well as of men. In this respect he was ever in the front rank, and never in the rear of his people. He was to them, literally, a pillar of fire by night, and a pillar of cloud by day; shielding them alike from darkness and from heat. Abraham Lincoln, great and good as he was, did not lead the thought and feeling of his country. He did not create opportunities or events, but he was wise enough to accept the advantages of both. He did not make public sentiment nor did he repress it, but he adjusted and timed his measures to its demands. And yet, these two men, so strikingly unlike in some important particulars, the products of different ages and civilizations, the outgrowths of different social conditions, the one a prince, the other a plebeian, the one a child of wealth, and the other a child of poverty; the one trained in all the learning of the schools, and the other self-taught and self-made, were stamped by nature with the same lineaments of a common nobility, and appointed to a common mission in the world.

"Both men were, as we have seen, at the head of fearfully divided peoples, and both possessed, in large measure, the high qualities needed to soften asperities and heal divisions among them.

"Both men had foes of their own households, and both had disguised traitors in their camps. "Both William and Lincoln were devoting them- 
selves, heart and brain, to their countries' service, while they were yet in the midst of their years, when the body and the mind are both at their best. Yet, before age had plucked the fire from their hearts or dimmed the light in their eyes, the heavy cares of state had plowed deep furrows on their brows. Similar qualities begat for each the same appellation. The countrymen of William soon learned to call him 'Father William,' and those of Lincoln learned to call him 'Father Abraham.' The people believed in each, and trusted each, as children believe and trust in their fathers. While Abraham Lincoln lived and was seen at the capital of the nation, the loyal people never lost hope. Though a hundred battles we fought and lost, Lincoln never doubted of success, and the people shared his confidence. In William, also, there was the same unwavering and unfailing trust. In another respect these men resembled each other. Both were remarkable for an extremely cheerful disposition, and withal for a capacity for the most serious devotion to whatever business they might have in hand. Both, too, were often berated for apparent levity. But in character, as elsewhere, extremes meet, and in this there is no contradiction. The man who laughs heartiest is the man who sorrows decpest, and the one extreme enables him to support the other. 
"While moving about between besieged cities, starving garrisons, and inquisitorial fires, bearing on his breast a responsibility heavier than that of any other man in his country, William still found moments for great cheerfulness, and even merriment.

"Men incapable of this feeling under such circumstances, reproached him for levity. They did not know that the farther the pendulum of the human mind swings in one direction, the farther it must also swing in the other direction.

"Great, loving hearts were in the breasts of both men. Their amiable qualities naturally called out and strengthened corresponding qualities in all who came about them. Resembling each other so closely in their temper, character, and relation to their times, it is remarkable that these two men should have resembled each other also in the manner of their deaths. Both were assassinated, the one by popery, the other by slavery, and both manifested the same spirit of charity.

"When William died, as he did die, by the hand of one of the most cold-blooded, persistent, and treacherous assassins ever known in history, an ungrateful wretch, who, only the day before, had received from the good man a charity,- he died, invoking mercy and pardon for his guilty murderer.

"Could our own Lincoln have spoken after the 
assassin's bullet went crashing through his brain, it would have been entirely like him to have implored mercy for his merciless murderer. "Malice toward none, charity toward all," was his motto in life and in death.

"It is worthy of remark, too, that William the Silent and Abraham Lincoln were alike fortunate as to the time at which they were called away from the stormy scenes of life. Both saw the mighty works of their great lives nearly completed, and died amid the glorious triumphs of their respective causes.

William, though long under the ban of pope and king, and denounced by both as an outlaw, though long pursued by assassins, though large rewards had been offered for any one who would murder him, though five different attempts had been made upon his life, lived to see his country free, his Spanish enemies worn out and broken down, the sectarian divisions of his country healed, the armies of Spain defeated and driven away from his country, its proud navies swept from the sea, and the pillars of the Dutch Republic, of which he was chief builder, firmly established.

"Men now make pilgrimages to the place where William fell, and, while freedom has a home anywhere on American soil, grateful pilgrims will find their way to the grave of Abraham Lincoln. 
"Great hearted men both! Though three centuries stretch away like an ocean, between your space in life and work, ye were cast in the same generous mold, ye were co-workers in the same great cause, and paid the same extreme penalty for your devotion, and together shall your memories be cherished forever."

At Baltimore, in $1876, \mathrm{Mr}$. Douglass for the first time delivered his celebrated lecture on The National Capital. Such sentences as would cause criticism when read apart from the lecture and out of their connection were telegraphed to Washington by prejudiced persons, and immediately he became a target of abuse for the entire press of the District. When the lecture was read and understood, it became a subject of praise rather than of abuse. The humor that runs through the description which Mr. Douglass gives of the office-holding and office-seeking classes will be appreciated by the reader.

The passage is as follows :-

"But I would do injustice in the matter of the population of Washington, if I failed to say a word of another element in the social composition of the capital, in no degree more agreeable and commendable than those already referred to.

"They are the spoilsmen of every grade and description. They are the office holders, office seekers, contract buyers, pension agents, lobbyists, 
commissioners, ard run-betweens in general. Men are here with all sorts of schemes and enterprises, some with claims valid and just and some with claims neither valid nor just. Some have to secure the extension of a patent which ought to be extended, and some are here to prevent such extension. Some are here to contest the seat of a sitting member and some are here to assist him. "Some are here to use their influence for friends at a distance who are too modest or too timid to come themselves, some are here with heads full of brains, pockets full of money, and faces full of brass, to lobby through Congress a great patriotic measure with millions in it, and all are here to get something for nothing if possible.

"The faces and movements of these men are a study, and the impression they make is far from pleasant. There is here and there in the crowd a face of genuine manliness and joy, but the majority of them are wrinkled, darkened, and distorted by lines that tell of cunning, meanness, and servility. They are restless, eager, and anxious.

"Nowhere will you find a greater show of insincere politeness. The very air is vexed with clumsy compliments and obsequious hat lifting.

"Everybody wants favor, everybody expects favor, everybody is looking for favor, everybody is 
afraid of losing favor, hence everybody smiles, bows, and fawns towards everyborly else, and everybody knows the full value and quality of this general self-abasement. You will seldom hear an honest, square, upright and downright no, in all this eagrer and hungry crowd. All look yes, and smile yes, even when they mean anything else than yes. In their large and well-worn pocket-books, many of them carry about with them carefully folded but considerably soiled papers, written in a solemn official hand earnestly recommending the bearer for any office or thing he may want, or he may be able to get, for when the former is impossible, the latter is always acceptable.

"It is easy to see upon slight inspection that some of these papers are very old and have seen much service and certify to character which may have been lost a dozen times since they were written, and thus the biggest rogues may sometimes have the best papers.

"The national capital is never without a fair representation of these hungry spoilsmen, but the incoming of a new administration is the signal for the gathering in force of this remorseless class. The avenues of the city and the corridors of the capitol and other public buildings are the literal whirlpools of social driftwood from every section of the republic.

"Its nembers are met with in all directions. 
They are crowding, elbowing, and buttonholing everywhere.

"The least offensive of this multitude are those who come here to obtain clerkships and other positions in the several governmental departments. There is nothing in this service proper, to degrade or to demoralize, and yet I cannot recommend any young man to seek this mode of livelihood. The process of getting and holding these offices is often both degrading and demoralizing. It plays havoc with manly independence and true selfrespect.

"They are usually obtained through intervention of members of Congress and other influential persons for political service rendered or to be rendered, and there is often a strong temptation to resort to improper means to make an impression upon those whose influence is sought for this purpose.

"All the dishonesty and duplicity in office seeking and in the pressing of claims are not on the side of this hungry crowd. The men who serve them or profess to serve them are not always sound or what they seem.

"A member of Congress has been known to give a confiding constituent a strong letter of recommendation to a position in one of the government departments and then by another street outrun the applicant to the department addressed, to say 
that no attention must be paid to it and that his name was only signed to the letter for buncombe. The apology for this duplicity and treachery is political necessity. He cannot afford to make a political enemy. He would doubtless very gladly give every voter in his district an office, but the voters are too many and the offices too few. He has two cats in his room and only one mouse in his closet. Hence, while he freely signs your papers he says to the heads of the departments, 'Pay no attention to my recommendations unless I personally accompany the applicant.'

"In this pre-eminently deceitful and treacherous atmosphere, promises even on paper do not amount to much. Everybody is fed and being fed upon great expectations and golden promises, and since the diet is less than dog cheap, nobody fails of a full supply.

"If you want any office and want help to get it, everybody will cheerfully promise to help you. Your member of Congress will do what he can for you. Your senator will do what he can for you. Your whole delegation will do what they can for you. The heads of various departments will do what they can for you, and even the president of the United States, who does not permit himself generally to interfere in the matter of departmental appointment, will do what he can for you. 
"The amazing thing, however, is that with all this gushing and abundant promise of help your name is not on the pay roll, you are still in the cold and your chances of getting in grow beautifully less, with every dinner your friends will permit you to take at Willard's, Wormley's, or Welker's.

"It is commonly thought to be a nice and pleasant thing to be a member of Congress, but I think it would be difficult for a man to find any position more abundant in vexation. A man who gets himself elected to Congress can seldom do so without drawing after him to Washington a lively swarm of political creditors who want their pay in the shape of an office somewhere in the civil service. They besiege his house at all hours night and day, break his bell wires before breakfast, crowd his doorway, if he is in he cannot get out without seeing them and if he is out he cannot get in without seeing them. They waylay him as he goes to his house and dog him to the very doors, and summon him to the cloak room or lobby after he may have been so fortunate as to have reached his seat in the House of Representatives. In all this sort of vexation and trouble he must be too polite or too prudent to express the slightest sense of annoyance. If he would be a successful politician he must face it all with the blandness, patience, and suavity of a true martyr." 
Mr. Douglass has attended all the national conventions of the Republicans since the nomination of Lincoln and has always been treated by the party leaders with marks of great respect and honor. At the convention held in Minneapolis in 1892 he occupied a prominent seat on the platform in rear of the president, Hon. William McKinley, Jr., of Ohio. In ISSS at the convention held at Chicago, being loudly and repeatedly called for, he made a short address which was heartily applauded by the entire audience. Mr. Donglass at this time was in favor of the nomination of Hon. John Sherman, whom he regarded as the leading American statesman and a true friend of the colored race.

Standing before that immense audience he said :-

"Mr. President: I had the misfortune last night, while speaking to a vast audience in the Armory, to break my voice so that I feel wholly unable to address you any more than to cxpress my thanks to you for the cordial welcome, the earnest call, you have given me to this platform. I have only one word to say and it is this, that I hope this convention will make such a record in its proceedings as to put it entirely out of the power of the leaders of the Democratic party and the leaders of the Mugwump party (laughter) to say that they see no difference between the Republican party and the 
Democratic party in respect to the class I represent. (Applause.) I have great respect for a certain quality I have seen distinguished in the Democratic party. It is its fidelity to its friends (laughter); its faithfulness to those whom it has acknowledged as its masters for the last forty years. (Laughter and applause.) They were faithful-I mean the Democrats were faithful-to the slaveholding class during the existence of slavery. They were faithful before the war; they were faithful during the war. They gave them all the encouragement they possibly could without drawing their own necks into the halter. (Laughter and applause.) They were faithful during the period of reconstruction. They have been faithful ever since. They are faithful to-day to the 'solid South.' I believe that the Republican party will prove itself equally faithful to its friends (cries of 'Good, good') and those friends during the war were men with black faces. (Cries of 'That's right!') They were eyes to your blind, they were shelter to your shelterless sons when they escaped from the line of the rebels. They are faithful to-day, and when this great republic was at its extremest need, when its fate seemed to tremble in the balance, and the crowned heads and the enemies of republican institutions were saying in Europe: 'Aha, aha, this great republican bubble is about to burst;' when your armies were melting away before the fire and 
pestilence of rebellion, you called upon your friends, your black friends; when your star spangled banner, now glorious, was trailed in the dust, heavy with patriot blood, you called upon the negro -yes, Abraham Lincoln called upon the negro (great applause) to reach forth his iron arm and clutch with his steel fingers your faltering banner; and they came, they came 200,000 strong. (Loud cheers.) Let us remember those black men in the platform that you are about to promulgate, and let us remember that these black men are stripped of their constitutional right to vote. (Cheers.) Leave these men no longer to wade to the ballot-box through blood, but extend over them the arm of this republic and make their pathway to the ballot-box as straight and as smooth and as safe as any other citizen's. (Cheers.) Be not deterred from duty by the cry of 'bloody shirt.' (Cheers.) Let that shirt be waved as long as blood shall be found upon it. (Cheers.) A government that can give liberty in its constitution ought to have power to protect liberty in its administration. (Cheers.) I will not take up your time. I have gotten my thoughts before you. I speak in behalf of the millions who are disfranchised to day. (Cheers and cries of 'Go on,' 'Douglass, Douglass! ')"

In Chicago January I, I893, on the dedication of the pavilion devoted to the exhibits from the 
Republic of Hayti, Hon. Frederick Douglass, one of the commissioners for the Haytian government, made an address which the reader will find interesting and instructive. He takes the opportunity here afforded to praise the courage and bravery of the Haytians in their struggle for independence and to pay in glowing language a graceful tribute to the great Toussaint in contrasting him with Napoleon Bonaparte.

"In taking possession of and dedicating this pavilion to the important purposes for which it has been erected, Charles $A$. Preston and myself, commissioners appointed by the government of Hayti to represent that government in all that pertains to such a mission, wish to express our satisfaction with the work thus far completed. His Excellency, General Hyppolite, has been the supreme motive power and the mainspring by which this pavilion has found a place in these magnificent grounds. The moment when his attention was called to the importance of having his country well represented in this Exposition, he comprehended the significance of the measure, and has faithfully and with all diligence endeavored to forward such resources as were necessary to attain this grand result. For ourselves as commissioners, under whose supervision and direction this pavilion has been built, I may say that we feel sure that Hayti will heartily approve our 


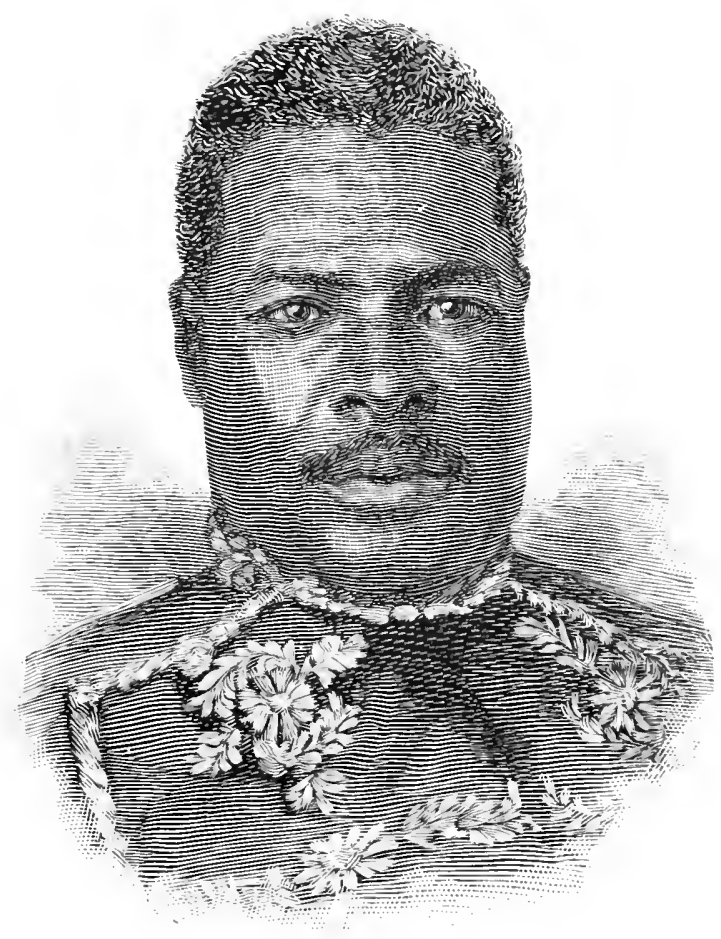

From Harjer's Weetly.

Copyrisht, Iung, by Harger o Brotlets.

GENERAI HYPOLITE. 

work, and that no citizen of that country who shall visit the World's Columbian Exposition will feel ashamed of its appearance or will fail to contemplate it with satisfied complacency. Its internal appointments are consistent with its external appearance. They bear the evidence of proper and thoughtful regard for the taste, comfort, and convenience of its visitors, as well as for the appropriate display of the productions of the rich, tropical country which shall be here exhibited. Happy in these respects, it is equally happy in another important particular. Its location and situation are desirable. It is not a candle put under a bushel, but a city set upon a hill. For this we cannot too much commend or be too grateful for the liberality of the honorable commissioners and managers of these grounds. They have awarded us ample space and a happy location.

"Hayti will be happy to meet and welcome its friends here. While the gates of the World's Columbian Exposition shall be open and shall welcome the world to this enclosure, the doors of this pavilion shall also be open and will give a warm welcome to all who shall see fit to honor us with their presence. Our emblems of welcome will be neither brandy nor wine. No intoxicants will be served here, but we shall give all comers a generous taste of our Haytian coffee, made in the best manner by Haytian hands. They shall find 
this coffee pleasant in flavor and delightful in aroma. Here, as in the sunny clime of Hayti, we shall try to do honor to that country's hospitality.

"We meet to-day on the anniversary of the independence of Hayti, and it would be an unpardonable omission not to remember that fact with all honor at this time and in this place. Considering what the environments of Hayti were ninety years ago; considering the peculiar antecedents of its people, both at home and in Africa ; considering their long enforced ignorance, their poverty and weakness, and their want of military training; considering their destitution of the munitions of war, and measuring the tremendous moral and material forces that confronted and opposed them, the achievement of their independence is one of the most remarkable and one of the most wonderful events in the history of this eventful country, and I may almost say in the history of mankind. I shall make no elaborate comparison of Hayti with ourselves. American independence was a task of tremendous proportions. In the contemplation of it the boldest held their breath and many brave men shrank from it appalled. But Ilerculean as was this task and dreadful as were the hardships and sufferings it imposed, it was nothing in its terribleness when compared with the appalling nature of the war Hayti dared to wage for its freedom and independence. Its suc- 
cess was a surprise and a startling astonishment to the world. Our war of the revolution had a thousand years of civilization behind it. The men who led it were descended from scholars, statesmen, and heroes. Their ancestry were the men who had defied the powers of royalty and wrested from an armed and reluctant king the grandest declaration of human rights ever given to the world. They had the knowledge and character naturally inherited from long years of personal and political freedom. They belonged to the ruling race of the world and the sympathy of the world was with them. But far different was it with the men of Hayti. The world was all against them. They were slaves accustomed to stand and tremble in the presence of haughty masters. Their education was obedience to the will of others, and their religion was patience and resignation to the rule of pride and cruelty. As a race they stood before the world as the most abject, helpless, and degraded of mankind. Yet from these men of the negro race came brave men; men who loved liberty more than life, wise men, statesmen, warriors, patriots, and heroes; men whose deeds stamp them as worthy to rank with the greatest and noblest of mankind; men who have gained their freedom and independence against odds as formidable as ever confronted a righteous cause or its advocates. Aye, and they 
not only gained their liberty and independence, but they have maintained it. They have never surrendered what they thus gained to any power on earth. This precious inheritance they hold to-day, and I venture to say here in the ear of all the world, not in a spirit of defiance, but in the confidence of the integrity of Hayti's people, that they never will surrender their inheritance.

"Much has been said of the savage ferocity and sanguinary character of the warfare waged by the Haytians against their masters and against the invaders sent from France by Bonaparte with the purpose to re-enslave them, but impartial history records the fact that every act of blood and torture committed by the Haytians during that war was more than duplicated by the French. The revolutionists did only what was essential to success in gaining their freedom and independence, and what any other people assailed by such an enemy for such a purpose would have done.

" They met deception with deception, ambuscade with ambuscade, arms with arms, harassing warfare with harassing warfare, fire with fire, blood with blood, and they never would have gained their freedom and independence if they had not thus matched the French at all extremes, ends and opposites.

"History will be searched in vain for a warrior more humane, more free from the spirit of revenge, 
more disposed to protect his enemies, and less disposed to practice retaliation for acts of cruelty than was Toussaint L'Ouverture. His motto from the beginning of the war to the end of his participation in it was protection to the white colonists and no retaliation of injuries. No man in the island had been more loyal to France, to the French republic and to Bonaparte; but when he was compelled to believe by overwhelming evidence that Bonaparte was fitting out a large fleet and was about to send a large and powerful army to Hayti to conquer and reduce his people to slavery, he, like a true patriot, and a true man, determined to defeat this infernal intention by preparing for effective defense.

"The world will never cease to wonder at the failure of the French and the success of the blacks. Never did there appear a more unequal contest. The greatest military captain of the age, backed by the most warlike nation in the world, had set his heart upon the subjugation of the despised sons of Hayti, and spared no pains, and hesitated to employ no means, however revolting, to compass his purpose. Though he availed himself of bloodhounds from $\mathrm{Cuba}$ to hunt down and devour women and children; though he practiced fraud, duplicity, and murder; though he scorned to observe the rules of civilized warfare; though he sent against poor Hayti his well-equipped and 
skillfully commanded army of 50,000 men; though the people against whom this army came were unskilled in the arts of war; though by a treachery the most dishonorable and revolting the invaders had succeeded in capturing and sending Toussaint in chains to France to perish in an icy prison; though his swords were met with barrel hoops; though a wasting war had defaced and desolated the country for a dozen years, Hayti was still free, its spirit was unbroken, and its brave sons were still at large in the mountains ready to continue the war if need be for a century.

"When Bonaparte had done his worst, and the bones of his unfortunate soldiers whitened upon a soil nuade rich by patriotic blood, and the shattered remnants of his army were glad to escape alive, the heroic chiefs of Hayti, in the year $\mathrm{ISO}_{3}$, declared its independence, and it has made good that declaration down to I 893. Hayti's presence here to-day in the grounds of this World's Columbian Exposition at the end of the 4ooth anniversary of the discovery of the American continent is a re-affirmation of its existence and independence as a nation and of its place among the sisterhood of nations." 


\section{CHAPTER XII.}

\section{Members of the Douglass Family.}

As has been stated elsewhere in this volume, Mr. Douglass married soon after escaping from slavery. His wife, Anna Murray, came originally from the eastern shore of Maryland, and lived for seven or eight years in Baltimore, where Mr. Douglass first met her. While she did not have the advantages of education in her girlhood days, she was a woman of strong character, with much natural intelligence. As a housekeeper, she was a model, and the practical side of her nature made her a fitting helpmate to her husband in his early struggles and vicissitudes. In manner she was reserved, while he, as is well known, is of a jocose disposition.

She was the financier of the family. It was a settled principle with Mr. and Mrs. Douglass never to incur debts. If an addition was to be made to their home, or if they had under consideration any matter requiring the expenditure of money, they first counted the cost, and then made sure that the means were in hand before entering upon their plans.

In her death, which occurred in Washington in I88I, husband and children suffered a great 
loss and a severe trial, for she was a good mother and a faithful wife.

Annie, the youngest child, died in Rochester when eleven years of age. John Brown, in his visits to Mr. Douglass' house, became attached to her, and she grew very fond of him. It is thought that her death was caused by the shock which she received on hearing of his execution at Charlestown, Virginia. Annie must have been a lovable child, for Mr. Douglass speaks of her as the "light and life of my house."

Frederick Douglass, Jr., the second son, was born in New Bedford, Mass., March 3, 1842. He with the other children was educated in the public schools of Rochester, New York. At an early age Frederick with his brothers Lewis and Charles aided in piloting runaway slaves to Canada through the underground railroad. During the war he was employed as recruiting agent for the state of Massachusetts and was engaged in business of like nature in Mississippi and surrounding states. He served as bailiff of the courts in the District of Columbia under two marshals.

In the year 187 i he married Miss Virginia L. Hewlett, daughter of Mr. Hewlett of Cambridge, Mass., whose son, E. M. Hewlett, Esq., is a successful lawyer of Washington. Mr. Douglass resembled his father in personal appearance. He 



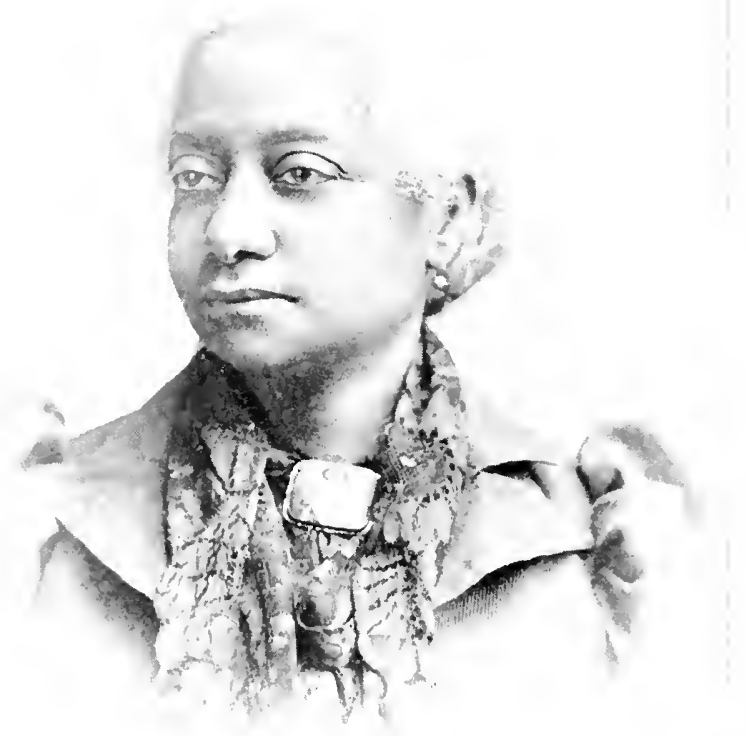

MkS. R. D. SPRMGLE,

bangher of Frederick louglaso 
was a man of ability, courteous in demeanor, and made many friends. He died in Washington, July, I892, the death of his wife occurring two years before this time.

Mrs. Rosetta Douglass Sprague, a lady of culture and engaging manners, was born in New Bedford, Mass., June 24, 1839 , and is the eldest child and only living daughter of Mr. Douglass. At six years of age she went to Albany, N. Y., to reside with Miss Mott, a friend of the family, where she remained three years. On returning home to her parents, who had now taken up their residence in Rochester, she and the other children were placed under the instruction of Miss Phebe Thayer, a Quaker lady who was employed as governess in the family, colored children at this time not being permitted to attend the public schools. It was now that Mr. Douglass began a fight for the admission of his children into the city schools, and in 1850 the school authorities yielded to his demands. The admission of these children was not only the opening wedge for the admission of other colored children, but abolished for all time the separate school system in Rochester.

At the age of eleven she was employed by her father in his office in folding papers and in writing wrappers. As she advanced in age and acquired skill and experience, she became his 
amanuensis, writing editorials and lectures at his dictation. For a time she studied at Oberlin, Ohio, and subsequently taught school at Salem, New' Jersey.

Miss Rosetta was married to Mr. Nathan Sprague in Rochester, December 24, $1863 . \mathrm{Mr}$. Sprague is engaged in the real estate business, and resides with his family in a beautiful home at 'Takoma Park in the suburbs of Washington.

Lewis H. Douglass, the eldest son, was born in New Bedford, Mass., October 9, r840. He was eight years old when the family removed to Rochester. His education was obtained in the schools of that city. He rendered valuable assistance in the publication of the newspaper conducted by his father. Enlisting in the $54^{\text {th }}$ Massachusetts Volunteer Infantry in the spring of 1863 , he continued with that regiment till 1864, when he was discharged for disability incurred in the line of duty. He held the important position of sergeant-major of his regiment, being appointed to that rank immediately upon his enlistment. He took part in the engagement on James Island, July IO, I863; was in the assault on Fort Wagner, July I 8, I 863 , and in the six weeks' siege following the famous storming of that fort, under which his health broke down, making his discharge necessary.

The beautiful words used by the poet in 


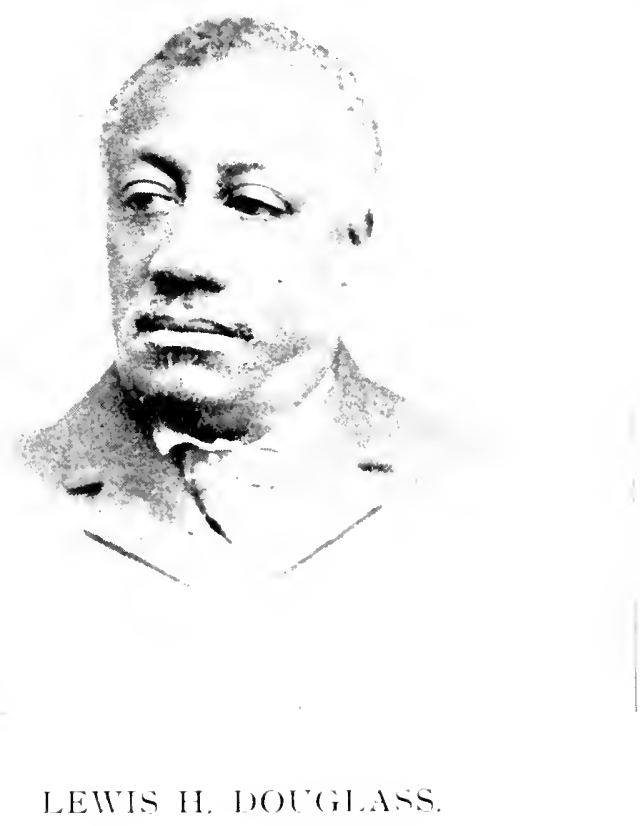



describing the conduct of the Black Regiment at Port Hudson, Louisiana, June, $186_{3}$, is descriptive, as well, of the action of that body of brave men who made the attack upon Wagner.
'“ Freedom!' their battle cry-
'Freedom! or leave to die!'
Ah! and they meant the word,
Not as with us 'tis heard,
Not a mere party shout ;
They gave their spirits out;
Trusted the end to God
And on the gory sod
Rolled in triumphant blood."

In Syracuse, N. Y., October 7, 1869, Mr. Lewis H. Douglass was married to Miss Helen Amelia Loguen, daughter of Bishop J. W. Loguen of the A. M. E. Zion Church.

For two years by appointment of President Grant, Mr. Douglass was a member of the council of the legislature of the District of Columbia, and for two years he was a special agent of the post office department. During the administration of President Hayes, he held the office of assistant marshal of the District of Columbia for the United States. For several years he has conducted a real estate office at $934 \mathrm{~F}$ street, Washington, and is regarded as one of the most successful business men of the race at the national capital.

Charles Remond Douglass was born in Lynn, 
Mass., October 21, I 844, and when five years of age entered the public schools of Rochester. Five years later he began folding and delivering his father's papers to city subscribers, leaving school one day in each week for that purpose. The breaking out of the Civil War found him engaged in farming. When only nineteen years of age, February 9, I863, he enlisted in the $54^{\text {th }}$ Massachusetts Infantry, being the first negro in the state of New York to enlist. Having served thirteen months in Company $\mathrm{F}$ of this regiment, he was transferred and promoted as first sergeant of Company I, 5 th Massachusetts cavalry, and remained with that command until near the close of the war.

He was married at Rochester, September 2 I, I 866, and in April of the following year was appointed to a clerkship in the war department. $\mathrm{U}_{\mathrm{p}}$ to this time there had been only one other appointment of a negro to a clerkship under the government of the United States. Assigned to duty with General O. O. Howard, commissioner of the Freedmen's Bureau, he served as confidential clerk to the commissioner and as clerk in the education division of the bureau. In 1869 he was appointed to a clerkship in the treasury department. Sometime prior to this he received, at the hands of Mrs. Lincoln, the cane commonly used by President Lincoln in his daily walks, 


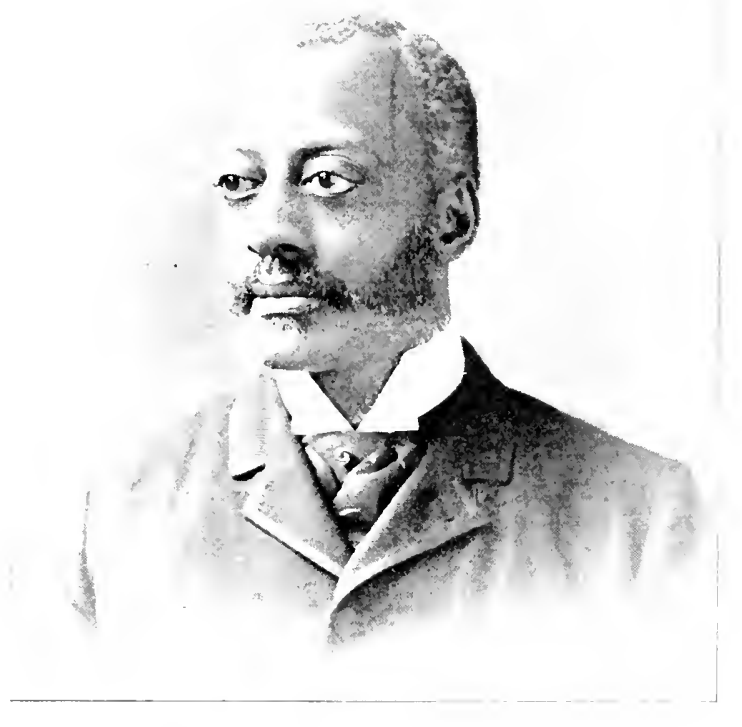

CHARLES R. DOUGLASS. 

with instructions to convey the same with her compliments to his father, Frederick Douglass, then residing in Rochester. In I87, having been detailed to accompany as clerk the annexation commissioners to Santo Domingo, he made with them the tour of the Island of Hayti and Santo Domingo. Four years after this he was appointed by President Grant United States Consul to Pureto, Santo Domingo, resigning in I 878 by reason of the last illness and death of his wife. Returning to America he settled in Corona, New York, where he was for a time engaged in the West India commission business. December 30, I880, he married Miss Laura $A$. Haley of Canandaigua, N. Y., and two years later was appointed an examiner in the Pension Bureau, where he is at present employed.

Since residing in Washington, Mr. Douglass has held several important commands in the District National Guard, has been a member of the staff of three commanders-in-chicf of the Grand Army of the Republic, and is at present major, commanding the Capital City Guard Corps, an independent military organization of Washington. Before the consolidation of the city and county schools, from 187 I to 1874 , he was secretary and treasurer of the county schools, filling during the same period the position of school trustee. In this latter position he was 
instrumental in securing the first appointment of colored teachers in the county schools, and it was largely through his efforts that the equalization in the pay of colored teachers and the whites was accomplished.

Frederick Douglass has followed with loving solicitucle the career of his children, and has done all in his power to advance their interests and promote their happiness. Now in his advanced age he has reason to be satisfied with the success which has attended them.

In the winter of $1884 \mathrm{Mr}$. Douglass married an Anglo-Saxon lady, Miss Helen Pitts of western New York. She is a lady of refinement and education, and possessed of pleasing manners. Mr. Douglass' married life is one of enjoyment and happiness. He and Mrs. Douglass frequently entertain friends from the city, on which occasions she presides with grace and dignity. 



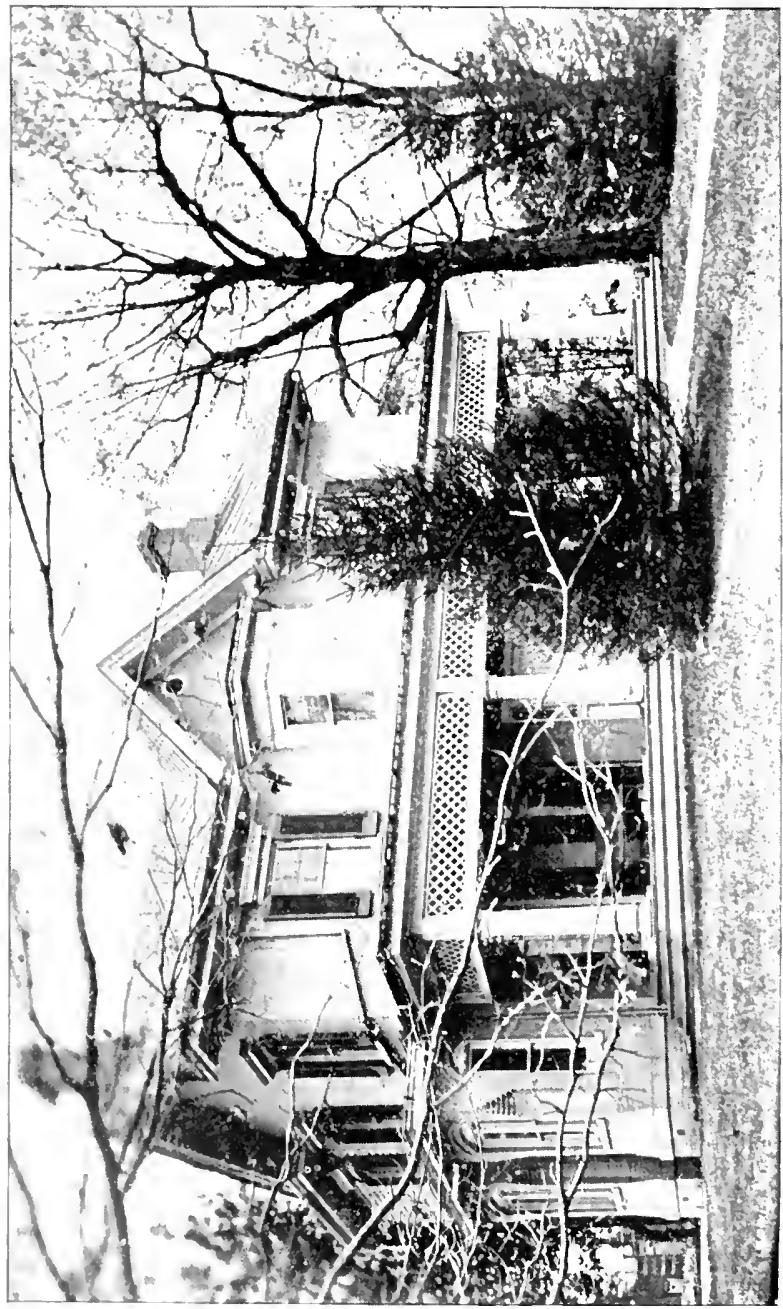

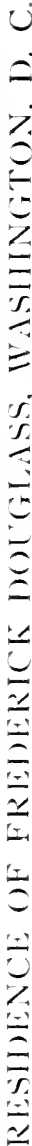




\section{CHAPTER XIII.}

His Home. - Personal Traits and CinakacTERISTICS.

The home of Mr. Douglass is at Anacostia, about three miles northeast from the city of Washington. Its situation is extremely beautiful. His house stands upon an elevation called Cedar Hill, which overlooks the Potomac and commands a fine view of the city and surroundings. The house of modest pretensions, commodious withal, is of Southern style of architecture, and, as all such houses are, was constructed with a view to comfort and convenience. You enter the front hall from a veranda extending the entire length of the house in front. From this veranda one has a view of the sunsets, which in this latitude are unparalleled for grandeur and beauty. On either side of the hall is a parlor, and back of the cast parlor is a library of well-selected books. This latter is Mr. Douglass' workshop where he prepares those lectures which delight and thrill so many audiences. Adjoining the front hall and west parlor is his dining room, where from time to time he has entertained many distinguished guests. In the front hall hang portraits of Charles Sumner and ex-Senator Blanche K. 
Bruce. There are also two portraits, one in either parlor, of Mr. Douglass. The first represents him in the early days of his anti-slavery career, the other in more mature life. In the west parlor over the mantel is a beautiful picture in water colors of Othello wooing Desdemona. This picture Mr. Douglass values very highly. On the walls of the library hang portraits of the African Cinque, of Toussaint L'Ouverture, John Brown, Abraham Lincoln, Hyppolite, and other illustrious men. The same simplicity which is characteristic of Mr. Douglass in his manner, in his dress, in his conversation, in his speeches, may be seen in the appointments of his house. All the rooms are tastefully but not extravagantly furnished.

That portion of the ground not reserved for an orchard and a garden is beautifully laid off in walks and drives. In the rear of the house is an cxtcnsive level tract which he has converted into a fine croquet ground. Here he may be seen any evening, when the weather permits, playing croquet with his wife and friends from the city. He is extremely fond of the game, and is usually the victor however skillful in play his antagonist may be.

Mr. Douglass is an excellent conversationalist. He cxpresses himself with correctness, ease, and elegance. He rivals Mr. Lincoln in telling anec- 

dotes. His stock of humor is an unendingsource of entertainment. When he has laid aside the restraints of office and public duty, he gives himself up freely to the pleasures and enjoyments of home. The vriter remembers one evening when he and other friends spent several hours in social converse with Mr. and Mrs. Douglass. Mr. Douglass seemed to be in one of his happiest moods. The presence of his guests called forth many reminiscences of his past life, and happy remarks of practical wisdom. Referring to the discouragements which young men encounter, he said that a man cannot ordinarily expect to rise to the topmost round of successful achievement by a single bound without taking the intermediate steps. He observed in the time of the California fever that those who took money with them brought back nothing; but those who went empty handed, depending on diligence and economy, returned in possession of wealth. Referring to his own early experience he said that in the first few years of his public life, having then a wife and four children, he received a salary of only three hundred and fifty dollars a year, but managed to lay by a portion of this for future use.

Speaking of the A. M. E. Church Review published by Dr. Tanner, of Philadelphia, which he had recently read, he praised it in glowing terms, and said that while it made no pretension to ex- 
cellence in artistic skill, it nevertheless contained valuable information set forth in well written articles. As the first literary magazine of the colored race, it is most creditable and we have reason to be proud of it. Twenty years ago a like production would have been impossible. He said he was engaged in reading the writings and speeches of Rome's ancient senators and statesmen, referring to his book-strewn table. In his reading he observed one thing in particular-the profundity and incisiveness of their style. Such laconic brevity is scarcely observable in the utterances of modern statesmanship. The Roman senator cracks the nut and gives you the kernel. We have not made much progress in these matters since that time. In answer to the suggestion as to the desirableness of an authentic publication of his lectures and speeches, he said it was his hope at some time to arrange them for publication, along with a collection of his letters. He wished something to be left as a memorial of his work, humble though it was. It might, in some way, help to weaken the force of the criticism some one has made that, "If the negro were sunk in the depth of the sea, all that the negro has done and the negro himself would be forgotten within twenty years."

During their visit, the company were served with tea, Mrs. Douglass presiding. The members 
of the party were deeply impressed with the generous hospitality of the host, and realized that they were in the presence of a man of varied experience, having a mind stored with useful knowledge; and the success of whose life illustrates the difference between mere knowledge and practical wisdom. On the departure of the company Mr. and Mrs. Douglass followed them to the door, and all were delighted with the charming beauty of the view of Washington and the Potomac illumined with the glory of the setting sun.

He is fond of music and often plays the violin accompanied on the piano by Mrs. Douglass. It is related that in earlier days while an exile in Scotland, passing along the street in a despondent mood he saw a violin hanging out at a store door, and going in bought it. He then went home, shut himself up, played for three days until he was in tune himself and again went out into the world-a cheerful man.

Mr. Douglass is of a bright and buoyant disposition at home as well as in public. An indication of his vivacity is shown in the fact that when confined in the Easton jail, with liability of being sold to New Orleans, he unraveled his socks and made a ball with which he played.

$\mathrm{He}$ is a man of temperate habits and strict in his business engagements: In Washington, as elsewhere, his word is his bond. He has accu- 
mulated a competency, the result of industry and economy. He has made it a principle of his life to save something out of his earnings, small though those earnings be. With all his habits of economy he has been a generous man, giving freely to every worthy cause. Numerous instances could be mentioned which would show how Mr. Douglass' purse has always been open to relieve misery and distress. He is often sought by persons, some seeking pecuniary aid and others employment. He seems always to have a due regard for the feelings and rights of others, even in the smallest matters. It is natural for him to be polite; it is not that artificial politeness which comes from studying books of etiquette, but it springs from his soul.

He is frank and fearless in expressing his views even though they bring him into sharp antagonism with those who hold different opinions. This was evidenced by his antagonizing his lifelong friends, the Garrisonians, upon the interpretation of the constitution, they holding that the constitution was pro-slavery in character and he that it was anti-slavery. Vials of wrath, so to speak, were poured out upon his head by the Garrisonian abolitionists when he proclaimed his views to the country, but Mr. Douglass was not driven from his position on that question. A man of ordinary courage would have been utterly 
overwhelmed by the great force of the opposition. Through a long and eventful life, he has never been known to deny his principles through fear or timidity or for the sake of temporary advantage. No one is ever long in doubt on which side of any important question he stands. Having satisfied himself which side is the right side, his course is neither vacillating nor uncertain.

He is a man of great force of will, and is very much like Mr. Garrison in this respect, who, it will be remembered, placed at the head of the Libcrator, when he first began to publish it, these words, "I am in earnest, I will not equivocate, I will not excuse, I will not retreat a single inchI will be heard." The success of the anti-slavery cause required that men of such force of character and determination should be its champions. Without them there could have been no success.

Mr. Douglass is one of the best examples the country affords of what a man of character and ability may become by energy and industry. Franklin, Henry Clay, Webster, Lincoln, Wilson, Garfield, and Grant are given as illustrations of the developing infuences of our country. These men all rose from poverty and obscurity to high places in the government, but Mr. Douglass sprang from depths which these men never knew in their experience. With them it was possible to obtain the highest honor in the gift of the 
people, and three of the men named did reach that exalted position. How different it was with Mr. Douglass, the slave, the fugitive, the exile. Twice was he compelled to flee his native land and seek shelter and safety under the flag of a foreign power. Not till the war ended was his freedom actually made secure. Even at this late day color stands as a bar against social recognition and political preferment in this country. If Mr. Douglass had enjoyed the same advantages enjoyed by his white contemporaries, and if the same opportunities for advancement had been open to him, what public position in this country might he not have filled, not even excluding the presidency? Had he like Clay and Webster been brought up in the profession of the law and afterwards transferred to the United States Senate, he would have become the peer of any in that body; for he has powers of mind which eminently fit him to grapple with the great questions that engage the attention of statesmen.

His influence on the colored race has been greater than that of any other man. He is endeared to them on account of his early struggles. They point with pride to his achievements and success; they reverence him because of his sterling qualities and spotless character. They recognize him as their most prominent leader, whose opinion they have always respected and whose 


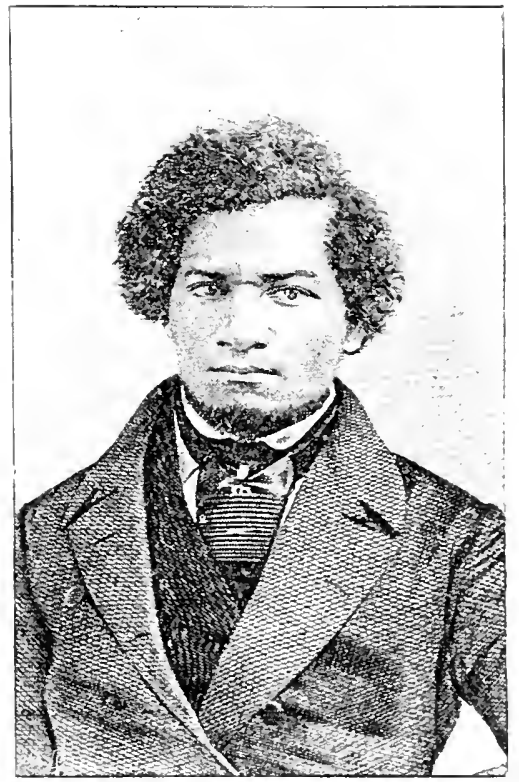

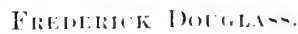

As a youner man. 


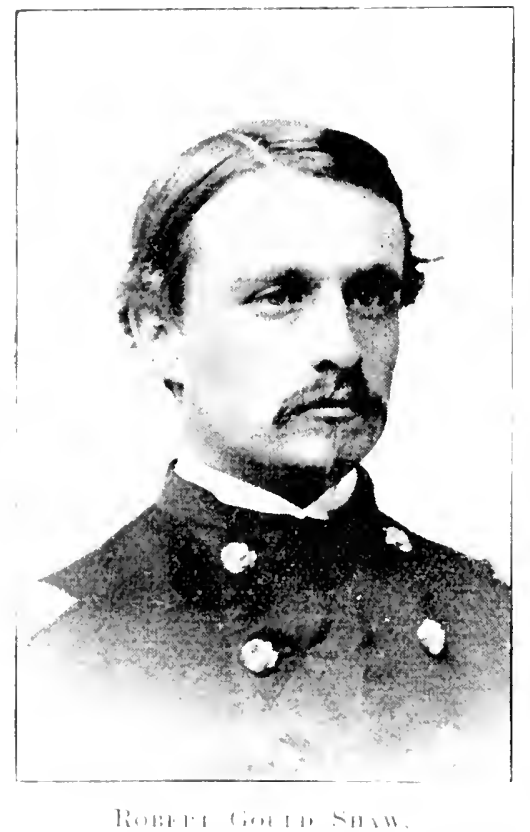

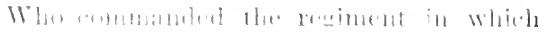

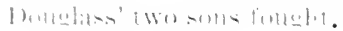


advice they have in most cases followed. But his influence is not limited to the colored race. He will always be an inspiration to struggling youth who are ambitious to win distinction, and he will always be regarded as a model of true eloquence. History, because of his excellence and achievements, will accord him a place in the galaxy of worthies whose fame is confined to no particular race or country. His is

"One of the few, the immortal names, That were not born to die." 


\section{CHAPTER XIV.}

Death of Frederick Douglass.-Funeral Services at Washington, D. C.

Frederick Douglass died suddenly of heart failure at his home, Cedar Hill, Anacostia, in the District of Columbia, February 20, I 895, at seven o'clock P. M., in the seventy-eighth year of his age. Until stricken he was to all outward appearances in his usual good health and spirits. Death came unexpectedly, giving no warning of its approach.

In the morning of the 2oth, Mr. Douglass came, with his wife, to the city, she going to the Congressional Library and he to attend the Women's Council, which was then in session at Metzerott Hall. Mr. Douglass, as a member of the National Woman's Suffrage Association, was naturally interested in the proceedings of all gatherings of representative women; hence his presence at Metzerott Hall. $\mathrm{He}$ was on this occasion specially honored by an invitation to remain through the secret business session of the Council, from which all persons except members were excluded. As he entered the hall the President, Mrs. Mary Wright Sewall, suspended business and designated the Rev. Anna H. Shaw and Miss Susan B. Anthony to escort him to the 
platform. He was then given an ovation by the audience, each member rising to her feet and waving her handkerchief. So much was he interested in the proceedings of the meeting that he remained through the morning session and at four oclock came back to the afternoon session; upon adjournment of which he returned to his home, where he arrived about six o'clock.

At the dinner table the family engaged in conversation upon the topics which had occupied the attention of the Council. After dinner the same subject was continued in the east parlor. In the midst of the conversation Mr. Douglass walked out into the center hall, when he suddenly fell to the floor without uttering a word. Mrs. Douglass, coming quickly to his assistance, saw at once that he was seriously ill. Being alone in the house, she ran to the front door and called for help. Several men, attracted by her cries, hurried to her assistance. A physician was immediately summoned. In a few minutes Dr. Stuart Harrison arrived and used every means in his power to revive the dying man, but without arail. The heart ceased its faint motion after twenty minutes from the beginning of the attack, and apparently without a struggle and without pain the great soul of Douglass passed to its final reward.

The announcement of his death spread rapidly through Anacostia and Washington and caused 
intense excitement. Every one, while expressing words of regret and sorrow, was ready to bear testimony to the high character and worth of the illustrious dead.

Mrs. Douglass, speaking to a reporter the night of her husband's death, said:-

His health had been the very best of late, and the great activity with which he preserved his interest in the events of the day had never permitted her to suppose that he was in the slightest decline of his vigor. He has never been troubled with heart disease, and such an end was far from his mind or any of those about him. She fully appreciated his public work, and it was but yesterday that he was talking to her with regard to his public life. She had expressed her belief to him that he was still called upon to live a public life, and he expressed his great desire to do so, and felt fully able and vigorous enough.

As a further evidence of his apparent vigor of health, he had made an engagement to speak that same evening at the Campbell A. M. E. Church of Hillsdale. Mr. Douglass breathed his last just as the carriage arrived which was sent to convey him to this church.

FUNERAL SERVICES.

The public funeral services of Frederick Douglass were held in the Metropolitan A. M. E. 
Church at two o'clock P. Mr. on Monday, February 25. Private services were previously conducted at the Douglass home by the Rev. Hugh ' $\mathrm{T}$. Stevenson, pastor of the Anacostia Baptist Church. At ten o'clock A. M. the remains were removed to the Metropolitan Church, to be viewed by the public. The body was met at the door of the church by the trustees of the church, J. W. Cromwell, A. P. Goines, John A. Simms, IVilliam Beckett, Jeremiah Johnson, James Ricks, and William Turley; a guard of honor furnished by the General Russell A. Alger Camp, No. 25. Sons of Veterans, Division of Maryland, in the fatigue uniform of the United States caralry, the detail in charge of Captain Judd Malvin, Past Captain John P. Turner, Lieutenant George A. Scott, Chaplain David M. Turner, Lieutenant Colonel Hamilton S. Smith, Sergeant Willis Madden, and Sergeant G. H. Woodson of the Tenth United States cavalry. Members of the guard of honor were detailed to stand at the head and foot of the casket as it rested on the dais in the church. The beautiful and numerous floral tributes which had been sent by friends, societies, schools, and the Haytien government were massed in front of the pulpit.

The day was an unusually bright and pleasant one for the season of the year. Not a cloud appeared in the sky. The sun shone out in all his 
brightness, as if to do honor to the dead leader. The closing of the colored public schools, of Howard University, of places of business conducted by colored men, and the general cessation of daily pursuits gave opportunity to the people to turn out en masse to show respect to the great commoner.

Long before the hour arrived for viewing the body, a countless multitude had gathered around the church and in the streets leading to it. At ten o'clock the doors of the church were opened and the public began to view the remains. The procession, which was a continuous one from this time on till the doors were closed at r.jO P. M., passed in at the east door, round the bier and out again at the west door. It would be impossible to say just how many persons passed into the church. There seemed to be no end to the procession, and when the doors closed not one-half of the waiting throng had been admitted. The following is quoted from the Washington Star: "When the doors opened at ten o'clock there was a crowding to see if those who had waited out of the long line, reaching down Fifteenth street, could not get in, but the police insisted on perfect order, and the procession of sad-faced people poured steadily into the church at one door and out at the other. The guards constantly cautioned those who lingered past the 
instant that gave a fleeting glance at the face of the dead. Some would have stood and shed their tears upon the casket, but the procession was kept moving, and no time was given for the demonstration of grief. It was a wonderfully impressive throng of people. There were whitehaired old men, who had known Mr. Douglass from the times when the struggle for race liberty began in this country. Fathers and mothers lifted little children to see the face of their champion. Men and women wept, and upon all there was the sober look of genuine sorrow for the death of a benefactor. Here and there in the long, persistent stream of humanity came one bearing a flower, a fern leaf, or a bouquet, which was silently laid upon the casket. Thousands upon thousands thus looked for the last time on the face of Frederick Douglass, greatest of their race in this age."

At two o'clock the pastor, Rev. J. T. Jenifer, D.D., reading the ritual, entered the church at the head of the funeral procession. Then came Mrs. Douglass on the arm of Lewis H. Douglass, eldest son of the deceased, the other children, with their families and immediate friends; the honorary pall-bearers, Hon. B. K. Bruce, W. H. A. Wormley, Hon. John R. Lynch, Hon. John F. Cook, E. C. Messer, Hon. P. B. S. Pinchback, Dr. C. B. Purvis, L. C. Bailey, John H. Brooks, J. H. 
Meriwether, Dr. John R. Francis, F. G. Barbadoes, D. L. Pitcher, B. E. Messer, Hon. George W. Murray and Dr. Robert Reyburn; the Trustees and Faculty of Howard University; delegration from the Women's Council. Among the distinguished persons in the procession were Senators John Sherman, George F. Hoar, Justice John M. Harlan of the United States Supreme Court, and Professor W. S. Scarborough of Wilberforce University.

In the pulpit sat the speakers and a number of persons specially invited.

On the front row of seats sat the twelve bodybearers taken from the ranks of the colored letter carriers of Washington, in full uniform: John H. George, Richard B. Peters, John W. Curry, W. H. Marshall, W. H. Cowan, H. W. Hewlett, Mercer S. Alexander, John D. Butler, Raymond Russell, and Dorsey Seville.

In the altar sat many pastors of city churches.

There were present delegations from New York, Philadelphia, Baltimore, Norfolk, Annapolis and other cities.

After the reserved seats in the body of the church, to the number of five hundred, had been filled the doors were opened to the public. Within a very few minutes every seat in the vast auditorium was occupied, a very small part of the great multitude outside gaining admission. 
The doors were then closed and the services began, the following order being observed:-

Hymn, "Nearer, My God, to Thee," read by Dr. J. W. Beckett.

Prayer, Rev. Alexander Crummell, D.D.

Hymn, "In thy cleft, O Rock of Ages, Hide Thou me."

Reading, Psalm xc., by Rev. J. W. Hood, D.D., Senior Bishop of the A. M. E. Zion Church.

Singing by choir, "Jesus my Saviour to Bethlehem came, Seeking for me," etc.

Sermon by the pastor, Rer. J. T. Jenifer, D.D.

A tribute by Rer. H. T. Stevenson, pastor of the Baptist Church of Anacostia.

Tribute by Rev. F. J. Grimke, D.D., read by Prof. George W. Cook.

Tribute by Dr. J. E. Rankin, President of Howard University.

Remarks and song, by Mr. John Hutchinson.

Remarks by Mr. Haentjens, Secretary of the Haytien Legation.

Remarks by Bishop A. W. Wayman, D.D., Senior Bishop of the A. M. E. Church.

Solo, Mr. M. H. Hodges of Boston.

A tribute from Mrs. Elizabeth Cady Stanton, read by Miss Susan B. Anthony.

Remarks by Mrs. Mary Wright Sewall.

Remarks by Rev. W. B. Derrick, D.D.

Reading of Communications, by Prof. J. W. Cromwell.

Benediction, by Bishop R. S. Williams of the C. M. E. Church of America. 
THE PASTOR'S TRIBUTE TO THE LIFE OF FREDERICK DOUGLASS.

An able and eloquent funeral sermon was preached by his pastor, Rev. J. T. Jenifer, D.D. He said :-

"Know ye not that there is a prince and a great man fallen this day in Israel?" - II. Sam., iii. 38 .

"And I heard a voice from heaven saying, Write, Blessed are the dead which die in the Lord from henceforth : yea, saith the Spirit, that they may rest from their labors; for their works follow with them." - Rev. xiv. I3.

Thursday last the peoples of five continents and the islands read with regret the sad intelligence: "Frederick Douglass is dead."

To-day the world unites in sympathy with us who sorrow for our great loss, by this death. We mourn the taking away of him who was our eminent and loved leader, and most illustrious example of our possibilities as a people, Frederick Douglass, a representative, ever faithful to his people, their champion, wise counselor, and fearless defender. Such a life as his is itself an oration, and this gathering an echo.

No man can give the people Frederick Douglass' funeral discourse; he has delivered that himself by his life and labors. $\mathrm{He}$ is in fifty years of his country's eventful history. Seventyeight years he was passing through the most thrilling epochs of his people's experiences in their land of conflicts and sufferings. 
Our text tells us of "a great man"that had fallen in the national struggles in Israel. All parts of history are tributaries to the vast whole, as rivers that go into the ocean help to make a whole.

It was the leading spirits among the Egyptian, Assyrian, Grecian, Hebrew and Roman peoples that made them so potent factors in the world's advance in civilization. Each of these peoples at its appointed time came into its place as a part of this vast whole of history.

The Hebrews have been large tributaries to the tide of the world's advancement. Moses, David, Abner, and their kind, evidenced their people's possibilities in leadership.

When this Republic entered as a tributary to this current of events, George Washington, preeminent among his followers, led them.

But let us not forget that the courses of each and all of the tributaries that run into and make the vast stream of human history are guided by the Almighty God, whose hidden hand directs the main current in its onward flow to the betterment and broadest happiness of mankind.

Our text says that Abner was a "great man." Men show themselves to be great as they evidence their abilities in overcoming difficulties in the achievements that benefit mankind. Where in history do we find a more eminent example of this than Frederick Douglass? 
What an inspiring example of possibilities the life of Frederick Douglass has set before young men! A hungry slave boy in trousers, tussling with the dog "Tip" for a crust of bread,- - the signboards are made his alphabet. From this he advances to the devourer of the contents of books; the carrier of great thoughts, the orator, the writer, lecturer, editor, author, the foreign traveler; the consort and counselor with great men and great women. He is the United States Marshal of the District of Columbia, the Recorder of Deeds, the Foreign Diplomat, and then the Haytien Commissioner at the World's Columbian Exposition.

He stands second to none in courage and abilities, among Garrison, Sumner, Phillips, Ward, Payne, Rock, and other brave and pure men and women, in the anti-slavery conflict. How full his life! How completely rounded out! How interwoven in the warp and woof of American history!

When any of the great questions involving his country's interest, or his people's welfare, had been spoken upon or written about, then what Douglass had to say was eagerly looked for. Because he always said something that gave an old subject a new setting, and threw upon a trite question a new light.

His comprehensive scrutiny and logical expressions in brief and best English compelled the discerning mind, though prejudiced, to say, "We 
never saw it in that light before." Hence in written matter, or platform oratory, or in companionship, Frederick Douglass was never an occasional man, but ever guarded, ever apt and ready; never clisappointing those who heard him. Coming into his presence, his simple, unassuming manner soon impressed you with the greatness of his character.

His tenderness of heart, love of little children and of young people, his high regard for womanhood, with that brave sympathy for human sufferings everywhere, marked the trend of his great soul. "He regarded man as man, and all men as brothers."

How befitting, therefore, was it for such a man to die on such an occasion, discussing with delight such a subject!

One whose life was devoted, as Mr. Douglass' has been, in conflict for manhood freedom, on what occasion, and from what place more appropriate for such a soul to take its flight from labor to reward than from an assembly of women of the world, who are striving for larger liberty and higher development of their sex in the interest of wife, mother, daughter, sister, and home!

FREDERICK DOUGLASS' RELIGIOUS CONVICTIONS.

A great deal has been said and written about Mr. Douglass' religious convictions, and of 
Frederick Douglass as a churcnman. What I shall say briefly upon this subject will be what I have been told by Mr. Douglass himself.

I first met Mr. Douglass at the home of my father, in New Bedford, Mass., in 1862; since which time I have known him well. The Washington Post, Thursday, February 21, said: "Freedom to Mr. Douglass meant not only freedom of the person. He believed in and was a brilliant champion for the vast liberty of the soul." But let no young man or person, in skepticism and love of $\sin$, by this fact be deceived and led astray from light and from truth, following Mr. Douglass' example.

Reflect that the liberty of the soul, which Mr. Douglass sought, was not license, but spiritual liberty in a broader sense than he conceived it to be in the American Church. Frederick Douglass was a converted man.

I heard him last summer tell the Methodist Conference in Georgetown, to which he was invited by Bishop Hurst: "I remember the time when I bowed at the altar in a little Methodist church that I now own, on Fell's Point, Baltimore; then and there I caught a stream of light and I have followed that light ever since!"

Mr. Douglass broke with the American Church and with American Christian dogma when be 
saw it made to sanction and defend the enslavement and bondage of a brother, with its horrible consequences. It was then that he advanced beyond his country and its church, to where Christ to him was larger than creed, and his Christianity transcended his churchianity. And from this point Mr. Douglass never retrograded; but he never ceased to reverence the God of humanity as he saw God.

In this terrific soul conflict Mr. Douglass told me that for a time he blundered into bewilderment, but God sent him deliverance. Last fall, at the office of his son Lewis, he explained this conflict to me in a conversation on religion. The crisis was reached when the Fugitive Slave Bill became a law. The National Domain became the enslavers' hunting ground, and any citizen liable to be made a slave catcher. He was then editor of the North Star at Rochester, N. Y.

Rev. Henry Ward Beecher; coming to the city, called upon Mr. Douglass and inquired, "Mr. Douglass, how are you?"

"I am all broken up. Done with your church, your Christianity, and your hypocrisy. You have given your country over to slavery and to slave catchers, and your church sanctions it as authorized by the Bible." Mr. Douglass said: "Mr. Beecher sat down upon the head of a keg, 
taking for hrs text, 'Alleluia: for the Lord God omnipotent reigneth' (Rev. xix. 6). Upon this, Mir. Beccher for a half-hour went into history, into science, reason, and into Scripture truths, with other facts, as only Mr. Beecher could. When I arose, I arose a changed and delivered man. Now," said Mr. Douglass, "I am in the trade winds of the Almighty."

Mr. Douglass has several times within a few months expressed to me the joy he experienced in God and in spiritual life. He was a constant worshiper here when weather and health permitted. He always called this his church, and took a deep interest in its welfare and in the affairs of the connection. He, several times, after listening to the sermon at the morning hour, has grasped the minister's hand, saying, "I have been greatly instructed, edified, and inspired this morning." Several times he told me how his soul had been thrilled by Dr. J. W. Beckett, when singing:-

\footnotetext{
İesus, my Sariour, to Bethiehem canee, Born in a manger to sorrow and shame. (). it was wonderful! How can it be? Seeking for me, secking for me.
}

Death has ended the career of the long, useful life of this great, good, and unique man. We can't say of him as of Abner, that he has fallen, but that he has risen, in that to a greater extent, 


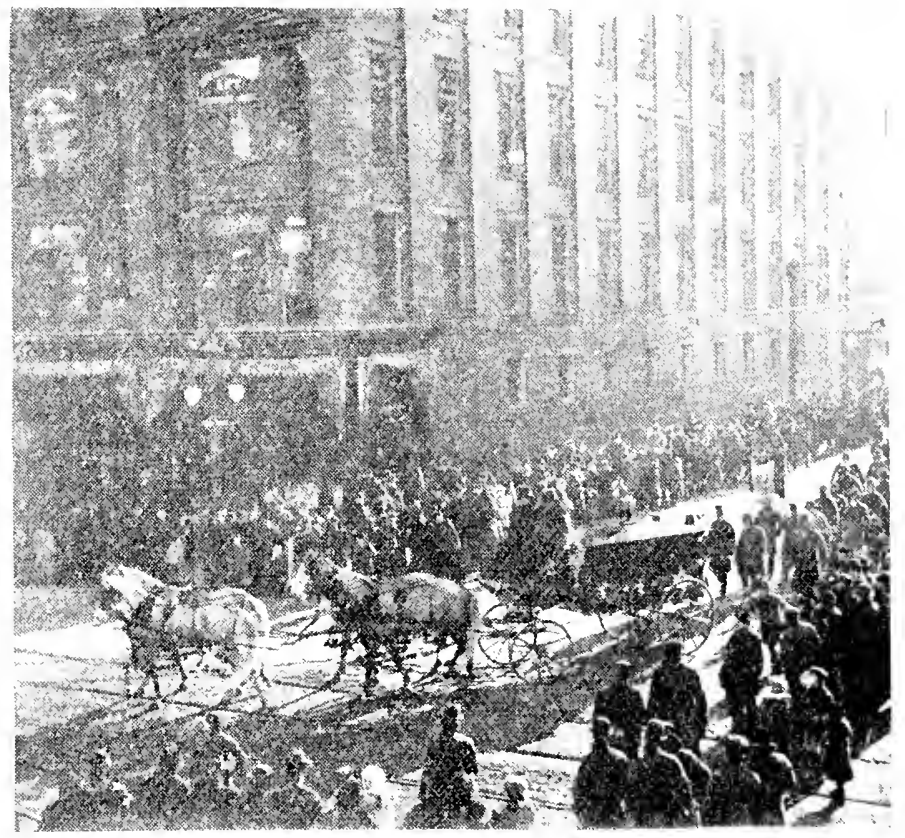

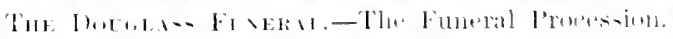




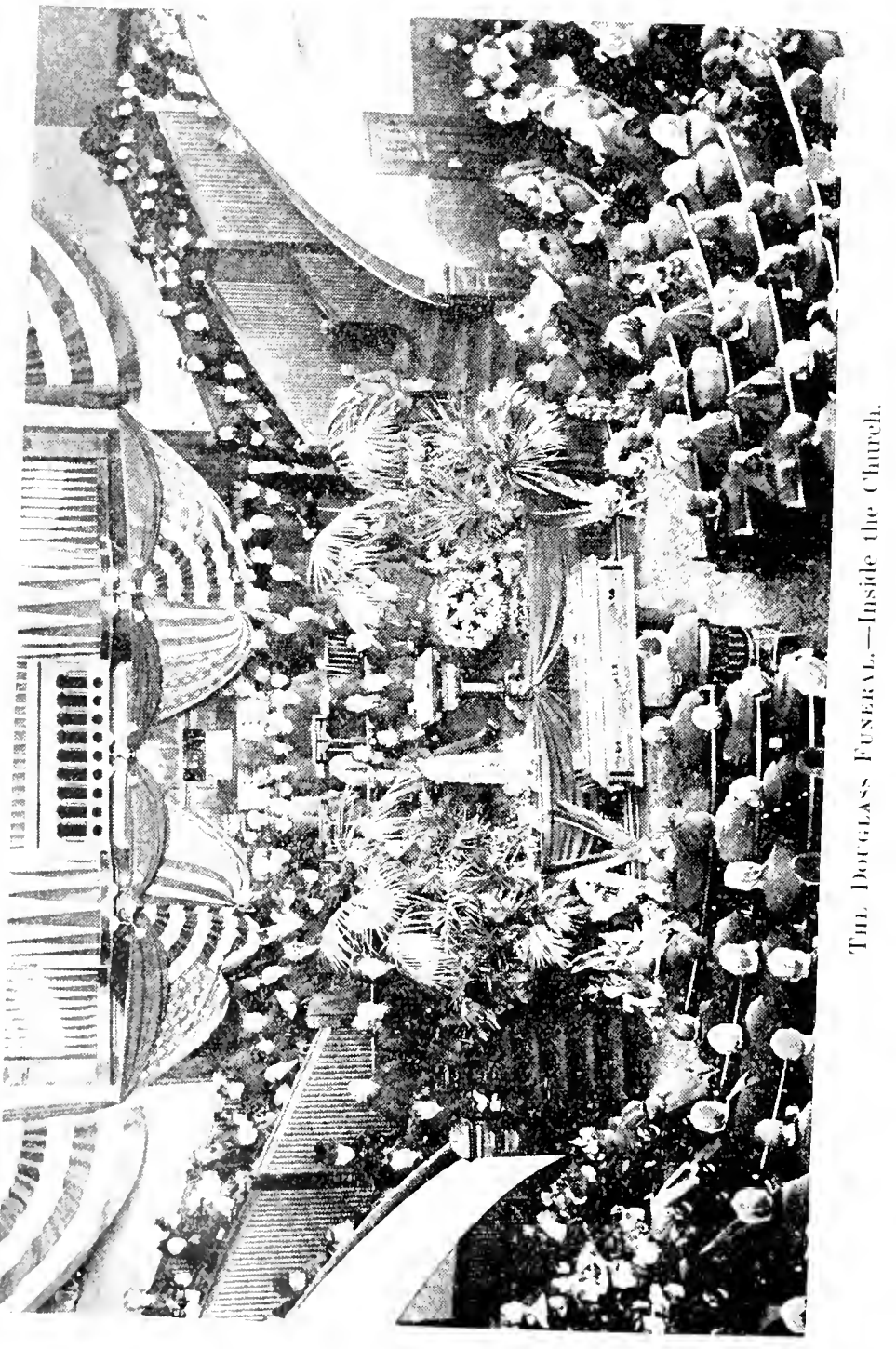


by his death, his true merits and character will be emulated. The hearts of the people will be cemented in closer bonds of sympathy for that, and for those for whom he so ably labored.

Douglass, the success, the student, worker, philanthropist, patriot, and leader, was given us by God, and the Lord has taken him.

"Blessed are the dead which die in the Lord from henceforth: yea, saith the Spirit, that they may rest from their labors; for their works follow with them."

On his return from the National Council of Women last Wednesday, February 20, the chariot of God met Mr. Douglass in the hallway of his home, when, without a struggle, while in the presence and in conversation with his beloved wife, the two alone, the spirit passed into the better land, in the seventy-eighth year of his age.

He leaves a wife, two sons, a daughter, and grandchildren to mourn his loss. He leaves a race in grief, the world of mankind in respect and regret, but heaven and earth will unite in saying, "Well done, thou good and faithful servant; enter thou into the joy of thy Lord."

Father, brother, leader, farewell! Dear family, wife, sons, daughter, grandchildren and relations, we commend you to the God of all grace in this, your deep affliction. Be you assured that you will never cease to have the deepest sympathy 
and the profound resiect of a grateful humanity for whom your great head gave his life and best efforts.

Rev. Hugh T. Stevenson, pastor of the Baptist Church of Anacostia, in his tribute to the memory of Mr. Douglass, spoke of the high character and transcendent ability of the deceased. It was his firm belief that when prejudice had died away the future historian would write of him as the greatest man of his time.

Rev. Francis J. Grimke, who could not be present on account of the death of his mother, in a letter, which was read by Professor George W. Cook, paid a loving tribute to the memory of his departed friend.

Rev. J. E. Rankin, D.D., LL.D., President of Howard University, in paying his noble tribute to the memory of the honored dead, eloquently said: -

"He sent a man before them; he was sold for a servant; his feet they hurt with fetters; he was laid in chains of iron: until the time that His word came to pass, the word of the Lord tried him."--Psalms cv. 17-19.

There is but one parallel to the life of Frederick Douglass, and this is found in the Bible; the Bible, which surpasses all other literature. There is no narrative which in natural pathos and eloquence so reminds me of the history of the favorite son of Jacob as the story of 
Frederick Douglass. And I find God in one as much as the other. And, I think, of all the men in his generation, so momentous of great events, so infuential upon future humanity, no man is more to be congratulated - could human congratulations reach him - than this man who now sleeps in death's marble before us. God made him great; yes, but God also gave him a great opportunity, and that opportunity beran when he was born a slave.

I feel the pathos of it, in every fiber of my being, when this boy, without father, without mother-save as once or twice in his memory she walked twenty-four miles, between sunset and sunrise, to give her son a few clandestine kisses,-yes, without beginning of days, for Mr. Douglass never knew the day of his birth, was, in that prison-house of bondage, slowly emerging to consciousness of himself and to consciousness of his surroundings. But that was his schooling for years to come. It was the only way in which he could become a swift witness against the great wrong which was crushing the bodies and souls of millions. It was the secrets of that prisonhouse of despair which the world needed to know. And God had given him the tongue of the eloquent to tell them. Fascinating as is the masterpiece of Harriet Beecher Stowe, beautiful, and touching as are the scenes depicted, dramatic 
as is the movement, powerful as are the delineations, we all know it is fiction. It is founded on fact. But this narrative is fact.

And I say that just as God sent Joseph down into Egypt preparatory to great events which were to follow: to save much people alive; just as His word tried him in the house of Potiphar and in the dungeons of Egypt, so it was with the boy, the young man Douglass. When he was praying there with Uncle Lawson, God was girding him for that day when he was to go from town to town, from state to state, a flaming herald of righteousness; to cross oceans, to gain admission to palaces, lifting up the great clarion voice, which no one who ever heard can ever forget or forget its burden. So that I say Frederick Douglass was fortunate in the misfortune of his birth. If he had not been born of a slave mother, one potent factor in the great work put upon the men and women of his generation would have been wanting. God wanted a witness. After Dante wrote his "Inferno" the people of Florence said as he walked their streets, "There goes the man who has been in hell!" What the cause of freedom wanted was a man who had been in hell; in the hell of human slavery, an eyewitness of the dark possibilities and experiences of the system into which he was born; who had felt the iron enter his own soul; who 
knew what it was to be compelled to yearn in vain for mother-love; to fight his way, inch by inch, into the simplest rudiments of human speech, of human knowledge, into any of the prerogatives of manhood.

\section{THE IEGINNING OF THE END.}

I do not at all underrate the work done by those magnificent champions of freedion who took this young man at twenty-five into the charmed coterie of their fearless eloquence; who gave him the baptism of their approval, who laid their hands upon his head, William Lloyd Garrison, Wendell Phillips, and their associates. But they needed him as much as he needed them. After their cool and eloquent logic, after their studied irony and invective, which, mighty as it was, was wanting in the tremolo of the voice of one that has suffered, of one whose very modulations signified more than their words; when this man arose, as one rises from the dead, as the ghost of one, the crown and scepter of whose manhood has been stolen away, while he goes from land to land proclaiming the wrong and asking for justice, then the climax was reached. This man made the work of such men as Garrison and Phillips and Sumner, and eren Lincoln, possible. I do not wish to use the languarge of exaggeration. It is not fitting the occasion. It 
is not in keeping with the dignified manner and methods of the man whom we commemorate, or the providential movement of which he was so long a part. But I believe that the birth of Frederick Douglass into slavery was the beginning of the end. And that this was just as ncedful to his anti-slavery associates as to himself. God planted a germ there which was to burst the cruel system apart. It was as though he said, "Go to, ye wise men of the Great Republic; ye Websters and Clays, miserable physicians are ye all. I will set this Samson of Freedom in your temple of Dagon, and his tawny arms shall yet tumble its columns about the ears of the worshipers. I will put the ark of my covenant in this man's soul, and the time shall come when your idol-god shall lie toppled over upon his nose in his presence."

I think that Frederick Douglass is to be congratulated on the kind of tuition that came to him-no, that God had provided for him, through these anti-slavery associates. They were regarded as the offscouring of the earth, and yet many of them received their culture in the choicest New England schools, and they sprang from the noblest New England stock. And when he went abroad it was his privilege to hear such men as Cobden and Bright and Disraeli and O'Connell and Lord John Russell 
and Lord Browham. These mein Mr. Poughass studicd, admired, analyzed. His more elaborate addresses, too, show the infuence of the first and greatest of New Engiand orstors, I aniel liebster. But, even beyond the great American crator, whose model orations are in all ont schoolbooks, was Mr. Doughas in ferver and fire. Ah! that was a day, when that maway slave heard that great statesman at Bunker Hill. And he once told me that he owed a rreat debt to the pocms of Whittier. To converse with Mr. Douglass, to hear him in public, one who knew his humble origin and limited opportunities might well ask, "How knoweth this man letters?" But, in the art of which he himself had such a mastery, he had the best teachers and examples the Anglo-Saxon schools could afford, while not one of the great men mentioned had such a theme as his. How carefully he improved his intercourse with such men, his observation of them, one has only to read his life to discover. Howard University, I believe, gave this man the degree of Doctor of Laws, and there were some laws that no man knew better how to doctor than he. But there was not an official of the university who could reach high enough to put a wreath on his brow. It had to be done from above, by the winged genius of the university. 


\section{CONTRASTS OF HIS LIFE.}

Then, in the third place, Mr. Douglass is to be congratulated on the wonderful contrasts and antitheses of his life. If we go on in the Psalm from which I have quoted we read: "The king sent and loosed him; even the ruler of the peoples, and let him go free. He made him lord of his house, and ruler of all his substance: to bind his princes at his pleasure, and teach his senators wisdom." The king that loosed this man was the King of kings and not Pharaoh, even as of old, till after the angel of war had smitten the firstborn of the land. If we except this prime minister of Pharaoh, perhaps no man who ever lived ever had such extremes and vicissitudes of experience as Mr. Douglass. There is probably no civilized nation on earth that has not been made acquainted with his wonderful story.

Perhaps he never saw a prouder day than when, as United States marshal-an official once so offensive to the sensibilities of a free people, because of his participation in the arrest and return of fugitive slaves-he accompanied President-elect Garfield from the Senate chamber to the platform of the portico, where he took the oath of office and delivered the inaugural address. This was the man who ran away from the neighboring state of Maryland, whose territory was once the ground on which the Capitol stands; 
who had twice exiled himself from his native land to cscape arrest, first as a fugritive slave, and then as in complicity with the John brown conspiracy; whose friends had actually paid the sum of $f_{\mathrm{N}}$ :50-I have this morning read the bill of sale again-to purchase his freedom from bondage, and who now acted as the representative of the United States in the moment of transition from the term of one President to that of another.

And if we turn from his public to his private career, what more striking and unusual scene. save perliaps Joseph's forgiveness of his brethrei. ever was introduced into the lot of man than his visit to his old and dying master, so many years after his escape from bondage? Was there ever an experience more pathetic? Was there ever forgiveness more generous? We pray, "Forgive us our debts as we forgive our debtors." This our great Teacher has taught us. The spirit of forgiveness is the basis on which we stand before God, who has so much to forgive in us; is the spirit which fits us for the kingdom of hearen.

\section{MR. DOUGLASS' ELOYUENCE.}

I come now to the last ground on which I think Mr. Douglass should be congratulated. IBy many it would be thought of first. Mr. Douglass was fortunate in his endowments as an orator. 
Eloquence is virtue. This the Germans have taught us. That is, there must be virtuous character, genuine truth and manliness behind all eloquent speech. A crafty, deceitful, dishonest, dishonorable man cannot be an eloquent one. $\mathrm{He}$ can deceive only the groundlings. His eloquence is all a sham and mockery.

Mr. Douglass had a commanding figure, a commanding presence, a commanding voice. In all these there is leadership. There was something more there. When he rose to his feet, when an audience saw that dignified and serious but kindly face, that venerable and seer-like aspect, when they heard that voice, it arrested attention and hushed every one to silence and expectation. Utterance with him was the considerate and judicious gathering of great forces; like the gathering of a storm in the sky; now and then a distant mutter, then the marshaling of the winds and the sweeping of the clouds across the horizon; then the descending thunderbolt and the lightning flash; then the rolling back of the clouds as a curtain, the return of the sunshine and the song of birds and the laughter of children. Mr. Douglass' voice was of unequaled depth and volume and power. And back of all this was a great-hearted, generous, forgivingnatured soul, who feared not the face of man and believed in the living God. 
Mr. Douglass never lost his sense of the proportion of things; never was unduly elated by his successes and achievements. He was uncompromising in his opinions and yet a patient waiter. He had a sagacious, a long patience for the result. When a great man is gone, for the first time we begin to see the space he filled, as though a mountain peak had been removed from our moral horizon. It will take a long time to measure the conservative and yet progressive influence of this great man; for he was great, and great in the period of great men. He was greater than his eloquent speech; he was greater than his life. If you write the history of the anti-slavery movement he was great there, it centered in him and around him; of the civil war and the reconstruction period, he was a man to whom presidents and senators, to whom millions of enfranchised people looked for counsel. He taught the senators wisdom. Shakespeare makes Mark Antony say over the form of the dead Casar: "My heart is in the coffin there with Cxsar." I know what that means to-day. Mr. Douglass had qualities that won the heart. No young man could know him without having for him a reverence that was filial. And wise will it be for the young men, whom he tenderly addressed as a father, if they heed his counsels, read his life, study his example, live as he lived. 
DOUGLASS, LINCOLN AND GRANT.

Mr. Douglass was a consistent man. He had no erratic moods or vagaries. There were men, great men, who drew away from Abraham Lincoln because, carrying upon his shoulders, like Atlas, this great American world, he seemed to move so slow. They were lighter loaded and could dance and cut capers along such a rugged pathway. But not Frederick Douglass. He saw where God was walking on that field and believed that Mr. Lincoln was walking with God. There were men, great men, who broke with President Grant. But not Frederick Douglass. He believed in the man who had fought the nation's battles through. And of Santo Domingo he said: "Since liberty and equality have become the law of the land I am for extending our dominion whenever and wherever such extension can peaceably and honorably be accomplished." A wiser saying to-day than when it was uttered.

If any man had a right to criticise and break down, if he could, the public policy of our great leaders and executives on the subject of human freedom it was Mr. Douglass. But he had not so lcamed the duty of a citizen, nor the art of statesmanship. It was his to suggest and counsel and then patiently wait. Lord Beaconsfield has said, "Everything comes, if a man will only" 
wait," and Philip II., "Time and I against any two," and Mr. Douglass has quoted, if he did not originate, that greater proverb, "One with God is always a majority." In that majority he was contented. For he knew that in His own time God would show himself, moving on His great affairs. It was this that made all his methods noble. There was no meanness in this man. He did not conspire and intrigue and backbite and undermine. He was no such mole as that. He was always above the ground, always acting in the open day. He did not poison his weapons and give the thrust of the assassin. But, standing in God's light, he fought what he believed to be God's battles against principalities and powers, with the weapons of a man. He gave hard blows, but never hit below the belt.

HIS DEATH.

In his autobiography Mr. Douglass describes the anxiety with which millions watched the breaking of the day when President Lincoln had promised to let loose the thunderbolts of war against slavery, and give the watchword "Freedom for all " to our gallant soldiers in blue, to see if it would be done. 'True as the movement of the stars, the mandate came. No such watching was his, when a few days since he was delivered from the entanglements and infirmities of this 
mortal prison-house, somewhat shattered in its walls by seventy-seven years' occupancy, where we all wait the emancipation act of our great Captain, of Him who has broken through the bars of death, and brought life and immortality to light in the gospel. The summons came as came the horsemen and chariots of Israel to Elijah, straight from the excellent glory, and before we could say, "My father," the splendid retinue of heaven had returned with their delivered guest, leaving only dust and ashes.

It was natural for Mr. Douglass to come back here to the bosom of the Methodist church. Here he sat in that draped pew, as said Professor Shedd, after resigning his chair, "Getting ready to die," saying to his old mother church that all the past was forgiven, repeating in his heart the words of Ruth to her mother, Naomi: "Thy people shall be my people and thy God my God," hiding himself anew, as he used to sing in his Anacostia home, in the "Cleft of the Rock" that was smitten on Calvary. She long ago had made him a preacher before he became an orator. This was the expectation and prayer of Uncle Lawson, while he was yet a slave. So that here, again, like a vessel that had made many a rough voyage, but now comes back to final anchorage, Mr. Douglass each Lord's day sat with his dearly cherished companion in this sanctuary of God. 
Call this man irreligious, an infidel? This man, whose foundations of truth and righteousness were established in God! This man, with whom one with the form of the Son of man had so otion walled in a hotter than a Nebuchadnezzar furnace. This man, with the spirit of God's kingdom, as the angels sang it, deep within him! Nay, call him father, brother, husband, friend! Have we forgotten the words of our Great Liberator in the synagogue of Nazareth, "The Spirit of the Lord God is upon me, because He hath sent me to preach deliverance to the captive"? Have we forgotten the epithets that were thick in the air about our Master: "Beelzebub! He casteth out devils through the prince of the devils"? Gentle with a womanty gentleness, wise with a wisdom beyond that of the universities, patient, long-suffering, and kind, always ready to forgive, always ready with the word of cheer; this is the man we mourn! Lips from which have fallen such golden eloquence, eyes from which have flashed such radiance, heart with such great throbs of sympathy for all God's downtrodden ones, hands which were always open and outstretched toward the wretched; these were his, these belonged to that man whom we called Frederick Douglass. Through the change of the greatest and most eventful period in American history, not once 
did he lose his footing; not once did he forfeit the companionship of our greatest; ay, not once did he lose his hold upon God.

Here is thy gratest son, my Maryland. Rise up to greet him as he passes through. Seventyseven years arro thou gavest him the birth of the bondman, but thou hast lost him. The nation has clained him - the wide world. Thou great Virginia planter, slceping by the Potomac, let the river bear thee these tidings: "What thou didst with thy bondmen, we have done with ours." The tread of the soldier is around thy slumber no more. And thou martyr-soul, beneath God's throne, to whom was given to speak the fiat of freedom to millions of men, women, and children whose lot was like this man's, who were thus "cabined, cribbed and confined" though God's image was in them, take this martyr-spirit to thy celestial companionship. And thou great Empire State, who gavest to this man a home, where he could earn his bread and rear his children, at a time when he had not where to lay his head, and by the broad flow of whose great river sleeps the dust of freedom's greatest captain, take to thy central heart and bear on thy bosom, as the ares sweep more and more into the sunlight of the man Christ Jesus, the battlescarred form of Frederick Douglass. Sleep, freedom's herald in the land of the frecborn. 


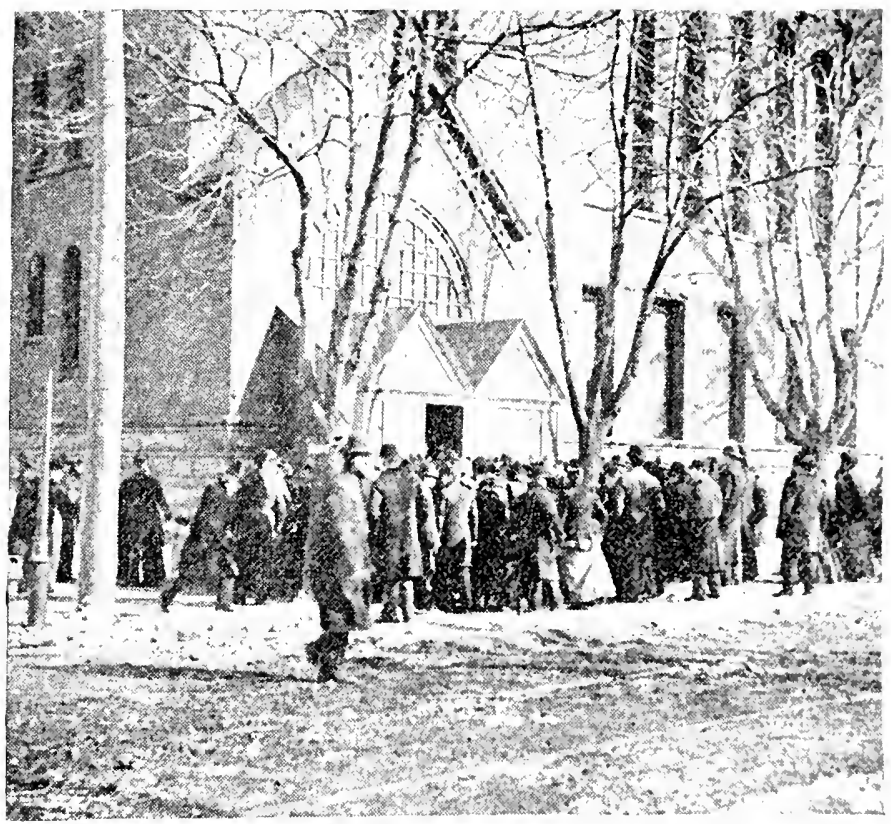

The Docglas Fineral. - In tront of the ('entral Chureh. 


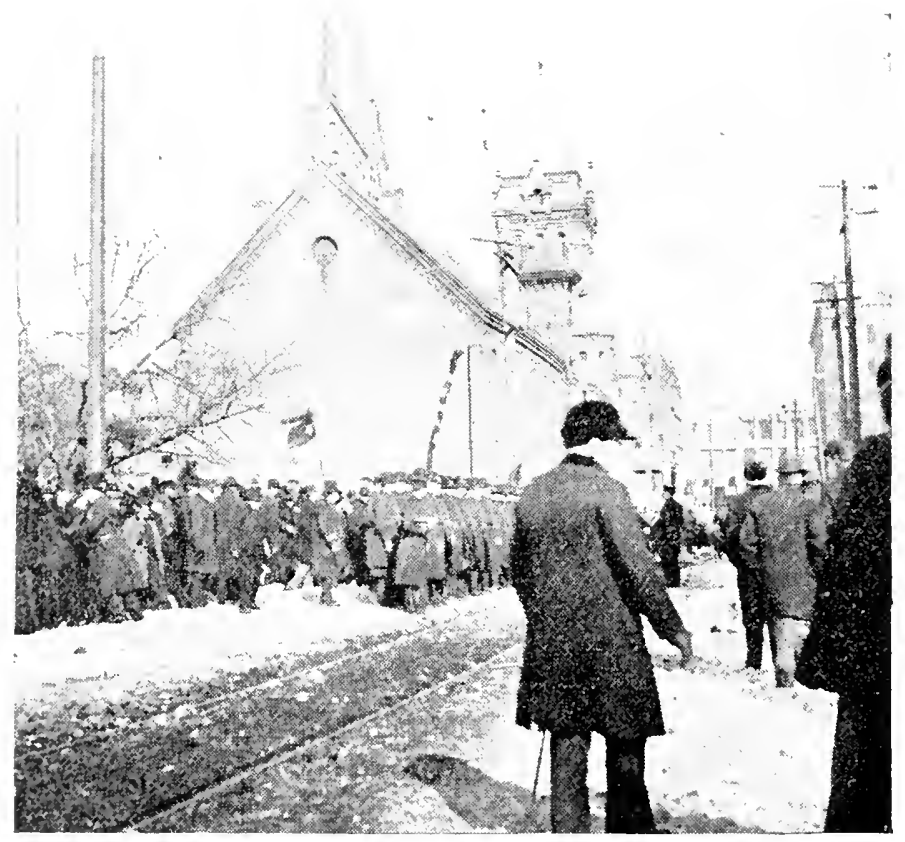

The Dor d.ass Fuxeral.-on Church street; the Line of March. 
Thine exile is over. Thou art dowered with the freedom of the city of God. All hail and farewell!

Prof. John Hutchinson came to attend the funeral, as the only survivor of the famous Hutchinson family and the only living representative of the "old guard" of abolition agitators. Though bearing the burcien of nearly fourscore years, his long hair and beard silvered by age, his step was firm and his voice strong and clear. It was his family that did so much in former days by their sweet songs to bring about the emancipation of the slave. He was present to pay his tribute of respect to his friend and coworker in the abolition cause. After speaking of his labors with Mr. Douglass, he referred to the scenes of the New York riots, when Douglass and Ward, two liberated slaves, with the white abolitionists, faced the angry mob. He spoke of other incidents in the life of Mr. Douglass - his fight against slavery and struggles for manhood rights, - and then chanted in a tone low and sweet a requiem ode to the dead, closing with the refrain:-

" Lay him low, lay him low

Under the grasses or under the snow :

What cares he? He cannot know.

Lay him low, lay him low."

In the absence of the Haytien minister, who was unable to be present at the funeral, Mr. 
Haenajens, socredary of the begation, represented the Haytion government. He expressed in the French language the personal regret of the mem. hers of the legation at the death of the man they all knew and loved, and also the regret of the Haytien republic over the loss of one who was the greatest benefactor of his race.

Hon. John S. Durham, ex-United States minister to Hayti, who was seated in the pulpit, came forward by request and translated into English the remarks of Mr. Haentjens.

Bishop A. W. Wayman of Baltimore, whose acquaintance with Mr. Douglass covered a long period, made a few appropriate remarks.

Rev. W. B. Derrick of New York followed in a brief address, dwelling upon the services which the deceased had rendered his race and mankind.

Miss Susan B. Anthony, after expressing the sorrow she felt at the death of Mr. Douglass, with whom her association had been especially cordial and friendly on account of like views entertained by them on woman suffrage and other questions of national interest, read the following letter from Mrs. Elizabeth Cady Stanton, who could not be present because of sickness:-

"Taking up the morning Tribune, the first words that caught my eye thrilled my very soul. 'Frederick Douglass is dead!' What vir d 
memories thick and fast flashed through my mind and held me spellbound in contemplation of the long years since first we met.

"Trained in the severe school of slavery, I saw him first before a Boston audience, fresh from the land of bondage. Hic stood there like an African prince, conscious of his dignity and power, grand in his physical proportions, majestic in his wrath, as with keen wit, satire, and indigrnation he portrayed the bitterness of slavery, the humiliation of subjection to those who in all human virtues and capacities were inferior to himself. His denunciation of our national crime, of the wild and guilty fantasy that men could hold property in man, poured like a torrent that fairly made his hearers tremble.

"Thus I first saw him, and wondered as I listened that any mortal man should have ever tred to subjugate a being with such marvelous powers, such self-respect, such intense love of liberty.

"Around him sat the great anti-slavery orators of the day, watching his effect on that immense audience completely magnetized with his eloquence, laughing and crying by turns with his rapid flights from pathos to humor. All other speakers seemed tame after Douglass. Sitting near, I heard Phillips say to Lydia Maria Child: 'Verily, this boy, who has only just graduated 
from the "southern institution" (as slavery was called), throws us all in the shade.' 'Ah,' she replied, "the iron has entered his soul, and he knows the wrongs of slavery subjectively; the rest of you speak only from an objective point of view.'

"He used to preach a sermon in imitation of the Methodist clergy, from the text, 'Servants, obcy your masters,' which the people were never tired of hearing. Often, after he had spoken an hour, shouts would go up from all parts of the house, "Now, Douglass, give us the sermon.' Some of our literary critics pronounced that the best piece of satire in the English language.

"The last time I visited his home in Anacostia I asked him if he ever had the sermon printed. He said, 'No.' 'Could you reproduce it?' said I. He said, 'No, I could not bring back the old feeling if I tried, and I would not if I could. The blessings of liberty I have so long enjoyed, and the many tender friendships I have with the Saxon race on both sides of the ocean, have taught me such sweet lessons of forgiveness that the painful memories of my early days are almost obliterated, and I would not recall them.'

"As an orator, writer, and editor, Douglass holds an honored place among the gifted men of his day. As a man of business and a public 
officer he has been pre-eminently succcssful; honest and upright in all his dealings, he bears an enviable reputation.

"As a husband, father, neighbor, and friend, in all social relations, he has been faithful and steadfast to the end. He was the only man I ever knew who understood the degradation of disfranchisement for women. Through all the long years of our struggle he has been a familiar figure on our platform, with always an inspiring word to say. In the very first convention he helped me to carry the resolution I had penned, demanding woman suffrage.

"Frederick Douglass is not dead! His grand character will long be an object lesson in our national history; his lofty sentiments of liberty, justice, and equality, echoed on every platform over our broad land, must infiuence and inspire many coming generations!"

\section{(Signed)}

ELIZABETH CADY STANTON. 26 West 6rst street, New York, February 21, I $\$ 95$.

Mrs. Mary IVright Sewall, president of the Women's Council, made a short but impressive address, in the course of which she used these words: "If our little world is made smaller by his departure, we may rest assured that there is a wider world beyond that is rendered greater still by his coming." 
Prof. J. W. Cromwell now read a number of letters from prominent persons, expressing their sorrow caused by the death of the great man, and regretting their inability to attend the funeral.

The Rev. Anna Shaw then offered a fervent prayer.

The services were closed with the benediction by Bishop R. S. Williams of the C. M. E. Church of America.

At 5.30 o'clock the casket containing the remains was borne by the pallbearers from the church to the hearse. The military escort, consisting of the Capital City Guards and a detachment of one hundred and fifty men of the colored camps of the Grand Army of the Republic, quickly formed into line, and the procession moved slowly to the depot. Arriving there the body was placed under military guard until the hour of 7.20, when it was carried over the Pennsylvania railroad to Rochester, New York, for interment. 


\section{CHAPTER XV.}

\section{Obsequies at Rochester, N. Y.}

Tunsar, February 26, the day on which the body of Frederick Douglass was laid at rest in Mt. Hope cemetery, vili ever remain a memorable one in the history of Rochester. On this day the city was in mourning and showed its respect for the man who was for so many ycars its distinguished resident. On the public buildings and on many business blocks the national colors floated at half-mast.

There were assembled at the depot, awaiting the arrival of the funeral train from Washington, the city officials,-Mayor Lewis, Aldermen Ashton, Cook, Green, McMillan, Dewey, Harris, Kelly, Tracy, Calihan, Rauber, Fox, Ward, Pauckner, Aikenhead, Simmelink, and Decker; the honorary and active pallbearers; the Douglass League, and a countless multitude of people, including many persons who had known $\mathrm{Mr}$. Douglass during his residence in Rochester.

The train bearing the body entered the central station of the Northern Central railroad at 9.25 oclock 1. r. Those accompanying the remains from Washington were the immediate members of the family and several friends. Included in 
the number were the following persons: the widlow, Mrs. Frederick Douglass; sons, Lewis and Charles; daughter, Mrs. R. D. Sprague; two granddaughters, Estelle and Hattie Sprague; grandson, Joseph Douglass; General John Eaton, ex-Commissioner of Education, representing the trustee board of Howard University, of which Mr. Douglass was a member; Prof. George W. Cook, representing the faculty of the same institution, and Mr. Julius J. Chilcoat, sent as a representative of the Asbury M. E. Church.

Upon the arrival of the train the pallbearers, reverently lifting the casket, carried it to the hearse, the people standing silent with uncovered heads. The Fifty-fourth Regiment Band leading, immediately the procession took up its line of march to the City Hall. This building was beautifully and elaborately decorated. The portico was draped with flags and heavy black bunting. From the ceiling and sides of the main corridor, where the body was to rest, were suspended the national colors and emblems of mourning.

The procession reaching the City Hall, the casket was placed in position on the catafalque, the Douglass League standing on the right and the honorary bearers on the left. Here the body lay in state from io A. M. to 2 P. M., and was riewed by thousands of people, including many 
prominent citizens. The pupils of the pulblic schools, accompanied by their teachers, were given an opportunity to view the remains, special arrangements having been mate for them.

The guard of honor at the hall consisted of Corporal Ray Crane, and Privates John Bricker, A. Birdsell, J. W. Sherman, and 13. R. Ordway, of the Eighth Separate Company of the National Guard; Lieutenant Schwarty, and patrolmen Kron, Moore, Maguire, Johnson, Moran, McAlester, Mullane, Shephard, Scholl, Klein, Sheehan, and Sullivan, of the Police Department.

The funeral cortege, leaving the City Hall at 2 o'clock, marched slowly to the Central Church. The Fifty-fourth Regiment band, playing the funcral march, led the procession. Then came the Eighth Separate Company, under command of Captain H. B. Henderson, followed by a platoon of forty-eight policemen in charge of Captain McDermott. The next in line were the active and honorary pallbearers in carriages, ingor, and members of the Common Council, and exmayors. After these followed the hearse, drawn by four white horses, richly caparisoned. Iicmbers of the Douglass League acted as an escort to the hearse.

When the cortege had reached the church the casket was carried to the front of the altar by the body bearers, the organist piaying the funeral 
march. Then followed in order the honorary bearers, the members of the family, and the persons who accompanied the remains to the city.

Five hundred seats were reserved in the center of the church for the family, pallbearers, friends, city officials, and organizations. After these were occupied the remaining seats in the great audience room of the church were rapidly filled. The seating arrangements were in charge of Mr. Henry H. Pryor.

The active pallbearers were C. P. Lee, William Allen, A. H. Harris, R. J. Jeffrey, R. L. Kent, Henry A. Spencer, F. S. Cunningham, and C. B. Lee; the honorary bearers, Hon. H. S. Greenleaf, J. K. Post, Hon. John VanVoorhis, Ex-Mayor Henry L. Fish, William Carroll, Richard Curran, Charles W. Briggs, George C. Clarkson, and N. C. Bradstreet.

In the pulpit were seated Rev. Dr. H. H. Stebbins of the Central Church, Rev. W. C. Gannett of the First Unitarian Church, the Rev. Dr. W. R. Taylor of the Brick Presbyterian Church, Rev. Dr. W. A. Ely of Zion African M. E. Church, Rev. J. E. Mason of Zion A. M. F. Church, Miss Mary S. Anthony, Superintendent of Police Cleary, Mayor Lewis, Aldermen Ashton, Cook, Green, McMillan, Dewey, Harris, Kelly, Tracy, Calihan, Rauber, Fox, Ward, Pauckner, Aikenhead, Simmelink, and Decker. 
A profusion of floral tributes from Rochester friends and from other cities were placed upon the casket and around the aitar. Palms and potted plants decorated the front of the pulpit, above which were draped large flags and mourning cmblems.

The funeral services were opened with the nymn, "Remember now Thy Cruator," sung by a cirartette composed of Messrs. Dowman, Hays, Milham, and Learned, after which the Rev. Dr. William R. Taylor, of the Brick Church, offered this prayer:-

"Unto Thee, O Lord, do we lift up our souls. "We are in the presence of a dread reality and a solemn mystery - the reality and mystery of death.

"But we are also face to face with a greater reality and a greater mystery - the reality and mystery of a human life that was full of divine goodness, divine feeling, and divine power.

"Only Thou who dost still continue to make men and women in Thine own image and share with them Thine own divine nature; only 'Thou who by Thy Providence dost rule in their affairs, bringing liberty and peace out of their bloody conflicts and a higher righteousness from their very sins; only Thou who didst kindle a divine fire within the soul of this man whose mortal body we are this day to bury in the earth, who 
didst give him his great heart and his eloquent tongue, and make him a power in the stirring and eventful period in which Thou didst cast his lot; only Thou couldst teach us the lesson of his life and through it fit us the better to serve Thee and our fellow men.

"We therefore entreat Thee for the influence of Thy Holy Spirit upon our spirits that we may see Thee and recognize the solemn realities, the noble opportunities and the unescapable responsibilities of our life. Forgive and cleanse us. Set us free from every form of bondage; teach us, lead us, help us, inspire us, and save us through Him who hath taught us to pray, saying, 'Our Father which art in heaven.' "

Then the Rev. Dr. W. A. Ely, pastor of the Zion A. M. E. Church, read scriptural passages appropriate to the occasion.

MR. RICHARDSON'S TRIBUTE OF RESPECT.

Mr. Sherman D. Richardson then read the following original poem :-

DOUGLASS.

I saw the slave of Maryland

Upon the soil of freedom stand.

The waves that once the Mayflower bore

Were dashing on New England's shore.

The Stars and Stripes showed Northern will

On breezes from old Bunker Hill;

And as he drank in liberty

I saw the man from serfdom free. 
I saw him like a monarch stand

With Lincoln's edict in his hand,

With lips infused from heaven's fire.

With thoughts that would all time inspire

Transfigured on Columbia's sod ;

A living type from Freedom's God ;

Incarnate soul of Liberty

He stood - a race and land were free.

I saw again God's pioneer

In grand repose upon his bier.

The lines that showed the reaper's path

Were softened with death's aftermath.

But yet that face more grandly taught

Of will and power, of battles fought,

Of victories won for Liberty.

The crown at last, the soul was free.

MISS MARY S. ANTHONY'S TRIBUTE.

Miss Mary S. Anthony began her remarks by saying that she felt that the women of Rochester must speak a word in eulogy of Frederick Douglass. Continuing she spoke as follows:-

"It is so seldom that any person, man or woman, born amidst the most unfavorable surroundings, making a life-work of the most unpopular subjects, lives as did this husband and father to see the world come to recognize the beautiful precepts of the brotherhood of man, that the most hopeful and best word one can say is, thank God and take courage.

"When we think of the first years of his life in our midst and compare them with the last visit he made here with the presidential party of 
Harrison, to take part in the dedication of the soldiers' monument, he being one of the honored guests at the Cottage banquet at Ontario Beach, we may well exclaim, 'The world cioes move.'

"The struggles and trials, and they were legion, which Frederick Douglass endured for seventyeight years, are to-day crystallized into a grand prophecy, of which this hour is the beginning of the fulfillment.

"The appreciation and love we, the women of Rochester, bear toward our friend and coworker cannot be better expressed than by reading the resolutions passed at the meeting of the National Council of Women in Washington."

Miss Anthony then read the memorial adopted by the Women's National Conference at Washington on the death of Mr. Douglass.

\section{DR. GANNETT DELIVERS THE FUNERAL ORATION.}

The Rev. W. C. Gannett, pastor of the Unitarian Church, was the principal speaker of the occasion. In part this is what the eloquent clergyman said:

"This is an occasion of grief, but perhaps more of pride. This is an impressive moment in the history of our city. There was a man who, when he became a fellow citizen here, lived in one of the humblest homes of the city; a man whose color exposed him to insult and rebuke, and a 
man whose race debarred him from the wealthier homes of the city.

"This man has come back home to-day. He did not come surrounded by the grace of a presidential company, as he did when he last came to Rochester, but he came in a little circle of his best beloved ones, and our city went forth to meet him at its gates. He has been welcomed for once in the most impressive manner. The Mayor of the city and other official representatives of its government have done him honor. He has been carried through the streets and the people have stood with their hats lifted as he passed.

"At our City Hall he has lain in state, and the very children of our schools have been dismissed that they might there view his remains in order that they may tell their children that it was their privilege to look upon the face of Frederick Douglass.

"And now at this hour, in this very city, thousands of people are gathered together to do him honor by their presence at least. This demonstration means at least two things. It is a personal tribute and an impersonal tribute. It is a tribute, not simply to this great public orator, but to the man who has exemplified before the eyes of all America the inspiring example of a man who made himself. Not all American citi- 
zens can make use of the opportunities which the country offers to them, but here was a man who, when his country held out the hand of opportunity, although it was a scanty hand, he made use of it and made more opportunities to use.

"Could there have been a future more unpromising than that before Frederick Douglass? Nature gave him birth, but denied him a father and almost denied him a mother. He was born a slave in $1_{1}$ I $_{7}$, forty years before anti-slavery was the word in the mouth of every citizen in the North. You know what the South was at that time, what a living hell was before the slave who tried to make freedom for himself. All of the Southern States were linked together in laws to hold the black man to the ground, and the law of the North required that fugitive slaves should be sent back to bondage. You know that public opinion in the North was against the slave. At that time in the South it was a crime for a slave to try to learn to read, and it was a crime punished by death for a slave to lift his hand against a white man.

"The North was pledged to send fleeing slaves back to that Southern hell. It was in that time that Frederick Douglass was born. What was his training? A kind mistress and a hard master. He had no school advantages. 
Even the college of the wood pile, the place of learning of so many self-made men, was denied him. The kind mistress, in her innocence, did give him instruction in the $\mathrm{A}, \mathrm{B}, \mathrm{C}$ 's, but a hard master was ever ready to give him the lash upon his back. It is difficult to say which of these did the young slave more good, but both tended to make him the Frederick Douglass whom we know. If you would know more about this read the chapter in his book called 'My Last Flogging.' Read the story of the two hours combat of the seventeen-year-old boy with his white master. Read the story of his final victory. Those two hours, he says, were the turning point in his life. At the end of that time he was still a slave, but he was a free man in his soul.

"Now the hope of liberty began burning in his breast. Then came his escape, and soon after it came the speech at Nantucket. Lord Byron wrote a book, it is said, went to bed and woke up famous. Frederick Douglass went to a little island off the New England coast, made a speech and sat down famous. From that time his career of fame increased. You remember him as an orator, for many of you heard the marvel of his princely eloquence, clothed in the poetical tones of him who was once a slave. It was then that he lived a quiet life among you, occasionally going away to deliver a lecture, and 
then coming back to edit his paper, which many of you read.

"Meanwhile history was making. All of the streams directly to the east of the Rocky mountains flow into the Mississippi river. So at that time all of the streams of national life were flowing into one valley, and that valley was the valley of slavery. War followed. The war ended and history was made. Frederick Douglass became a free American citizen; he became Elector-at-Large of the state of New York; he became Marshal for the District of Columbia; he became Minister of the United States Government to Hayti; he became a leader in oratory and a part of the nation's history.

" $\mathrm{He}$ is here in our presence to-day and we are paying tribute to him. Not alone do we pay tribute to him because he was a self-made man. He was a man of large heart. Who ever had greater opportunity to be large hearted? And who ever needed more to be large hearted? When the lash was lifted from his back still the line was drawn. He was always under that opportunity of sensitiveness, but under that chronic race sensitiveness, the victim of chronic insult, there beat a heart of chronic forgiveness, a heart of charity, an ever growing charity.

"Frederick Douglass was a gentleman born. Although he grew up under insult he became a 
kinglygentleman. That was Frederick Douglass. If you and I have never challenged long and loud public sentiment of our day, never will tribute like this await us. It was because he lived in the dark and cold reproach that we now bring him into the warmth of this tribute. It is not simply a tribute to the man. A personal tribute loses itself in the thought that it is transfigured in the impersonal. We are here honoring the race of Frederick Douglass. White people have assembled here to do honor to black people. Here is an instance of kingly mind, of kingly heart, of kingly manner; an instance of honoring him and honoring his race.

" Not only do I like to think that in the 150,ooo people of Rochester but three or four will be picked out twenty years hence as first citizens, but that of these two will be of those who have been bond men and bond women. And one of the two is lying here before us to-day. Few people in Rochester ever became famous throughout the state; very few people in Rochester ever became famous throughout the whole of America, but here is a man whom the newspapers of two continents have printed editorials about during the past week. He is one of the three or four who may be called the first citizens of Rochester.

"We have as yet but one bronze monument 
upon the squares of Rochester. Shall the next be of Frederick Douglass, wonderful orator and ex-slave? I hope so. If this wish is realized Frederick Douglass will not only represent an individual, but something grander. That monument of bronze already erected in our city not only represents Abraham Lincoln, but surrounding the statue of bronze are all of the elements which contributed to the success of the North. So the life of this man stands as the representative of his race. It stands for all that $\sin$ of slavery through which it forced its way, making that insult to a nation's history bend and break.

"I hope that this monument will stand on the streets of Rochester before our boys grow up to be men. A part of the nation's history is this man's emancipation from slavery and the emancipation of his race from insult and prejudice. His life spans the whole distance from the awakening of the national conscience in the few antislavery fanatics to the great hallelujah of the end which saw no shadow of slavery. We cannot do this man honor without honoring the nation.

"Let me add one great sentence, the greatest ever uttered by the lips of an American, and those lips were Frederick Douglass'. It is a sentence of but six words, but they are worthy of the Bible:-

" One with God is a majority.' 
"That is a sentence for all reformers. There is no need to fear or falter if you are one with God and your cause is right. Frederick Douglass spoke those words. Those eyes that you have often looked into are now sightless, and that voice that has stirred the deepest and best sentiments within you is now silent. He has come home."

By request Mr. George $\mathrm{W}$. Walton sang an adaptation of "Hide Thou Me." This was Mr. Douglass' favorite hymn. The other selections rendered were, "Lead, Kindly Light," and "Gathering Home." The music was under the direction of George W. Walton and Frank N. Mandeville.

INVOCATION OF RLV. DR. STEBIBINS.

The final prayer and benediction were pronounced by Rev. Dr. H. H. Stebbins, of the Central Church. He said:-

"Almighty God, who hast been our dwelling place in all generations, in whose hand are our lives, who hast appointed the bound of our habitation, we are here reverently and humbly to worship Thee, to acknowledge the benefits with which every day is loaded, to confess our manifold unworthiness, to supplicate Thy continued favor, and especially to bow submissively before that divine decree that has removed from our nation one of its most distingruished citizens. 
"We bless Thee for the man. We bless Thee, above the color of his face and the bondage of his earlier years, that with such scant opportunity, that throughout the severe hardship, the extreme peril, the violent prejudice, and the bitter persecution to which he was exposed, he was and remained the man.

"We bless Thee for the divinely implanted instinct of freedom that could never essentially make him a slave to any man. We bless Thee for the character he developed, for his steadfast devotion to his race, for the great ideas that stirred him, for the honest heart, out of the abundance of which he spoke; for his fidelity to conviction, for his steadfastness, and for his ready and active sympathy; and we bless Thee for the effective pen and the eloquent tongue that gave such brave expression to what was in him. We bless Thee, most of all, for his faith in God, a faith that wrought by love, that purified the heart, and that stimulated to manifold encleavor. We bless Thee that between the birth of the man and the death of the man there lie so many fruitful years. We bless Thee for the irave fight he fought, for the course he so nobly finished, and for the faith he kept. Surely a crown of life has been awaiting him, and now he wears it. Surcly he has been welcomed into the higher life with the greeting, "Well done, good 
and faithful servant.' We would add our tribute of respect, and rratitude, and admiration, and affection. We bless Thee that so much of the grood that men do lives aiter them, and that he, whose mortal remains lie before us, being dead, yet speaketh. Help us to hear and to heed the lesson his notable life teaches. Let our admiration inspire imitation, make us better men, men of God, men of faith, men of action, truer to conviction, more ready to do and to dare, for God and man, for country and world.

"Apply Thy balm of consolation to the wife and family of Thy deceased servant. Comfort all who mourn over this event. We thank Thee for the safe conduct, thus far, of these precious remains. Attend them to the resting place, where we shall gratefully and sacredly cherish them. Bless our city. Into our municipal life may there enter such laws and such administration as shall make us an upright, happy, contented, and united community. Bless our belored land. Bless our President and his inmediate advisers, our Congress, the Governors of our States, the Judges of our Courts, and all who bear any authority. Help us, stimulated by the lives of worthy citizens who have gone to their reward, to cultivate the righteousness that exalteth a nation. Bless all lands and all peoples that on earth do dwell. Nay government become 
more liberal. May God be universally acknowledged as Father, and may all men live together as brethren.

"The grace of our Lord Jesus Christ, and the love of God, and the communion of the Holy Spirit, be with us all. Amen."

\section{AT MOUNT HOPE.}

At the close of the services in the church the procession re-formed and slowly proceeded to Mt. Hope cemetery. The streets through which the cortege passed were thronged with great crowds of people. Sorrow was depicted on every countenance, and many were the kind expressions heard as the great champion of human freedom and equal rights was borne to his final resting place.

When the procession reached the cemetery the Rev. Dr. W. R. Taylor, of the Brick Presbyterian Church, conducted, in the presence of the family and a few friends, the burial service, simple, but impressive. The body was then placed in a vault temporarily. Later it will be interred in the family burying lot, which is one of the most beautiful sites of Mt. Hope cemetery. 


\section{CHAPTER XVI.}

On Sunday, March IO, I 895 , a large congregation assembled in the Fifteenth Street Presbyterian Church, Washington, D. C., to hear the obituary tribute paid by the pastor, the Rev. F. J. Grimke, D. D., to the memory of Mr. Douglass. Dr. Grimke, in his discourse, gave a complete and splendid philosophical analysis of the life and character of the deceased. A study of this sermon will be instructive and inspiring.

\section{SERMON BY FRANCIS J. GRIMKE, D.D.}

"And the king said unto his servants, Know ye not that there is a prince and a great man fallen this day?"-II. Sam. iii. 38 .

On the evening of the 2oth of February there passed from the stage of action the greatest negro that this country has yet produced; one of the most illustrious citizens of the Republic, and one of the most remarkable men of the century now drawing to a close. The shock which the announcement of his death produced was all the more startling, inasmuch as it was entirely unexpected. There was nothing to indicate that the end was near. Suddenly, unexpectedly, the summons came, and in a moment the nobls form 
which all men knew and delighted to look upon was laid low.

To say that we miss him, that we are deeply, profoundly saddened by the thought that we shall no longer hear his voice, nor see his face in our social and public gatherings,- that we shall no longer have his great, strong arm to lean upon, and his wise counsel to guide us in the hour of darkness and doubt, in our efforts to solve the perplexing problems which still confront us as a race in this country, in the face of a cruel and bitter race prejudice,-is but feebly to express the sentiment that we all feel this morning. As David felt over the death of Jonathan, so do we feel. II. Sam. I : 17-27. "And David lamented with this lamentation over Saul and over Jonathan his son: * * * * Thy glory, O Israel, is slain upon thy high places! How are the mighty fallen! Tell it not in Gath, publish it not in the streets of Ashkelon; lest the daughters of the Philistines rejoice, lest the daughters of the uncircumcised triumph. Ye mountains of Gilboa, let there be no dew, nor rain upon you, neither fields of offerings: for there the shield of the mighty was vilely cast away, the shield of Saul, not anointed with oil. From the blood of the slain, from the fat of the mighty, the bow of Jonathan turned not back, and the sword of Saul returned not empty. Saul and Jonathan were 
lovely and pleasant in their lives, and in their death they were not divided; they were swifter than eagles, they were stronger than lions.

"How are the mighty fallen in the midst of the battle! Jonathan is slain upon thy high places. I am distressed for thee, my brother Jonathan: very pleasant hast thou been unto me: thy love to me was wonderful, passing the love of women. How are the mighty fallen, and the weapons of war perished!" The sorrow, the deep, the almost inexpressible sorrow, which this man felt for his dead friend, do we feel for this great man, who has now passed beyond our ken, "into the silent land, into the land of the great departed."

Our purpose this morning, however, is not to use this occasion to pour out our lamentations, but rather to look back over that remarkable career, covering a period of nearly eight decades, with the view of forming some estimate of the man, of the debt we owe him, and of getting from his life courage and inspiration for the future.

\section{AS TO THE MAN.}

By nature he was cast in a great mold,physically, intellectually, and morally. Physically, what a splendid specimen of a man he was,-tall, erect, massive, and yet moving with the grace and agility of an Apollo. How Phidias or 
Michael Angelo would have delighted to carve in marble or to cast in bronze that noble form and figure. It was always a pleasure to me just to look at him. His presence affected me like some of the passages of rugged grandeur in Milton, or as the sight of Mont Blanc, rising from the vale of Chamouni, affected Coleridge, when for the first time he looked upon that magnificent scene. I think all who came in contact with him felt the spell of his splendid presence. The older he grew, the whiter his locks became, the more striking was his appearance, and more and more did he attract attention wherever he appeared, whether in our streets or in our public assemblies. I was never more impressed with this fact than at the great Columbian Exposition in Chicago. One morning I had the pleasure of going with him to the art gallery. There were several things that he wanted to show me, he said. The first thing we stopped before was a piece of statuary_- "Lincoln Dying." We had been standing but a few moments before a great crowd gatherce about us. I was absorbed in what he was saying; and did not at first notice it, but he tosk in the situation at once,-it was an old story to him,-and said, "Well, they have come, let us pass on." And wherever he went in the building the same thing was repeated. It seemed to me as if nearly everybody knew him; 
but even people to whom he was entirely unknown were quickly attracted by his remarkable appearance.

Intellectually, what a splendid specimen of a man he was! His intellect was of a very high order. He possessed a mind of remarkable acuteness and penetration, and of great philosophical grasp. It was wonderful, how readily he resolved effects into their causes, and with what ease he got down to the underlying facts and principles of whatever subject he attempted to treat. Hence, he was alway's a formidable antagonist to encounter. No man ever crossed swords with him who was not forced to acknowledge, even when he clid not agree with him, his transcendent ability. He had the faculty of seeing at a glance the weak pcints in an opponent's position, and with the skill of a trained dialcctician knew how to marshal all the forces at his command, in the form of facts and principles, in refutation of the same. It was to me a constant delight to witness the play of his remarkable powers of mind, as they came out in his great specches and published articles. He had a strong, mighty intellect. They called him the Sage of Anacostia: and so he was,- - all that that term implies, - wise, thoughtiul, sound of judgment, discriminating, far sceing.

Rovaly, what a splendid specimen of a man 
he was,-lofty in sentiment, pure in thought, exalted in character. Upon the loftiest plane of a pure and noble manhood he lived and moved. No one need ever be ashamed to call his name. There he stands, in the serene, beautiful white light of a virtuous manhood. For more than fifty years he has been before the public, not infrequently during that time the object of the bitterest hatred, and yet during all these years, in the face of the strongest opposition, with the worst passions arrayed against him, no one has dared even to whisper anything derogatory of him, or in any way reflecting upon the purity of his life, or upon the honesty and integrity of his character. There have been among us, in the past history of our race, men who were richly endowed intellectually, and who like him also possessed that rarest of gifts, the mighty gift of eloquence-men who could hold entranced great audiences by the hour, the fame of whose eloquence has come down to us; but when you have said that of them you have said all. Beyond that you dare not go. When it comes to character, which infinitely transcends all mere intellectual endowments, or even the gift of eloquence, we are obliged to hang our heads and remain silent, or go backwards and cover their shame; but not so here. No one need ever hang his head when the 
name of Frederick Douglass is mentioned, or feel the necessity of silence. No man need ever go backward to cover anything in his life. There is the record, covering a period of more than fifty years, read it, and put your hand upon anything in it, if you can. Character, character, has been one of the things that his name has always stood for. Physically he was great, intellectually he was great, and morally he was great. Had he not been, whatever may have been his other gifts and graces he never could have risen to the place of power and influence which for more than a generation he has occupied. He never could have won for himself the universal respect in which he is held to-day. Had he not been sound morally, we should not be here to-day to say what we are saying, nor would any such gathering as assembled in this city a week ago last Monday, to pay the last tribute of respect to his memory, have been witnessed. It was because, in addition to the admiration which all felt for his transcendent intellectual endowments, and his marvelous eloquence, there was the conviction that back of, and beyond, and above all these, there was a pure and exalted manhood. It was because we could say of him as Mark Antony said of Brutus,-

"His life was gentle, and the clements

So mix'd in him, that Nature might stand up. And say to all the world, This was a man." 
One of the things that I am especially proud of to-day is that this greatest representative that our race has yet produced, was a pure man, a man of unblemished reputation, a man of sterling integ. rity of character, whose example we can commend to our children, and to the generations that are yet to come.

Let us make much of this, and let the fiat go forth, let it ring out from every pulpit, and from every schoolhouse, from every hilltop and from every valley, that any man who aspires to leadership among us must be pure. In the presence of the splendid record that is before me, with the full knowledge of what this man was, of what his sentiments were, I stand here to-day and, in the name of Frederick Douglass, I say to this black race, all over this country, Stand up for a pure leadership; honor the men, and the men only, whose character you can respect, and whose example you can commend to your children.

\footnotetext{
"God give us men,-

Men whom the lust of office does not kill,

Nen whom the spoils of office cannot buy,

Men who possess opinions and a will,

Men who have honor, men who will not lie;

Tall men, sun-crowned, who live above the fog

In public duty, and in private thinking."
}

And such was the great man whose memory we honor to-day. 


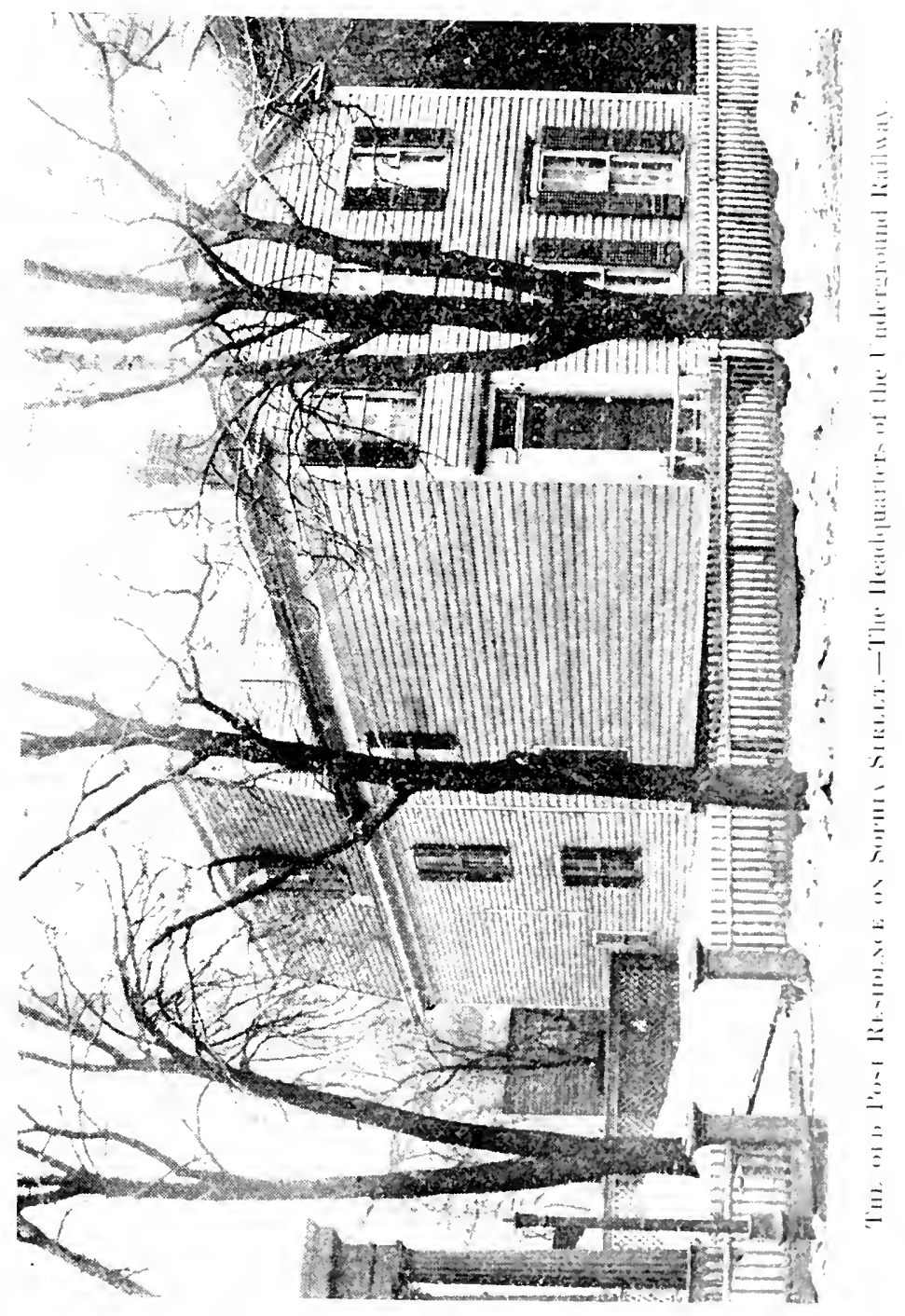




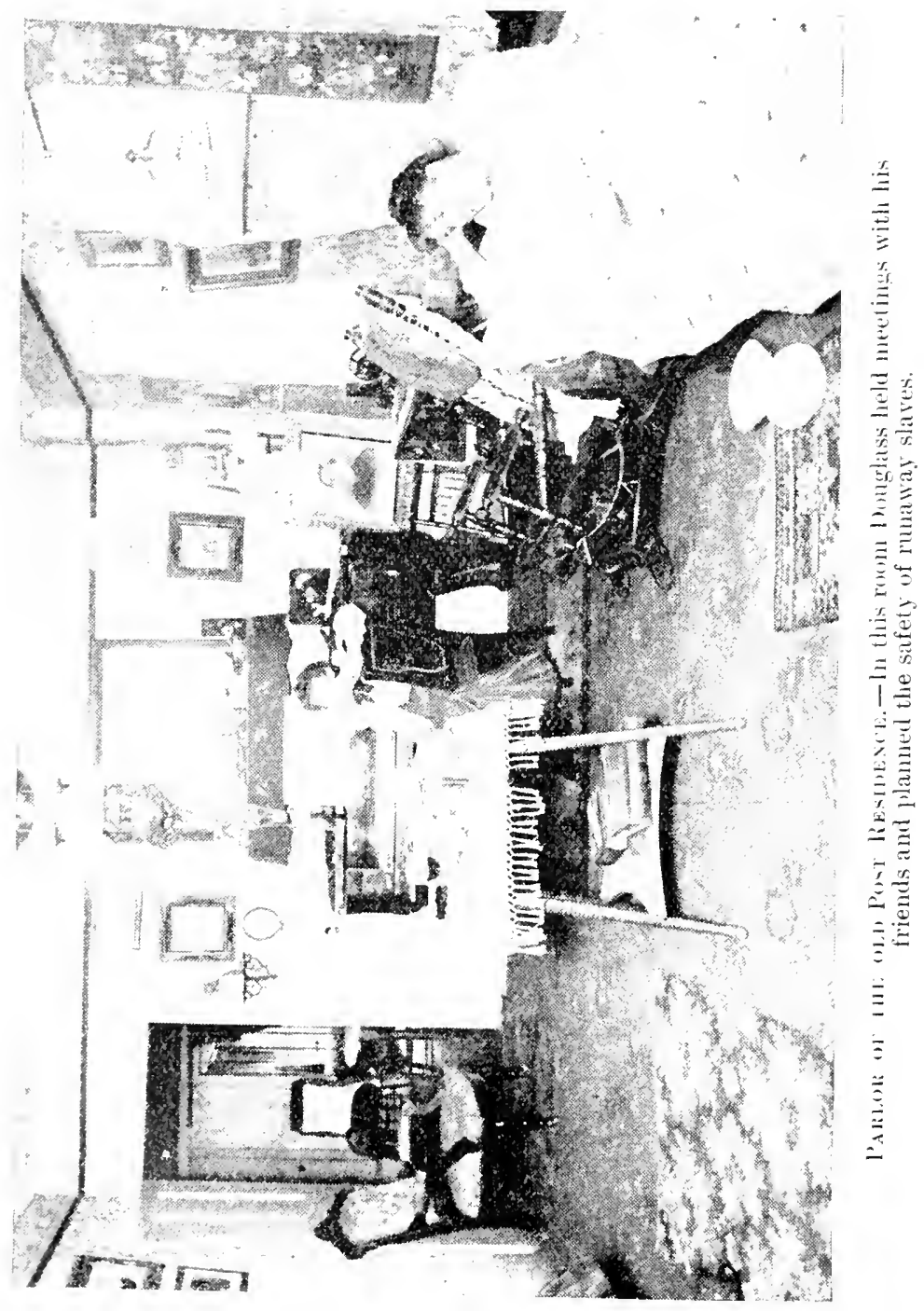


"Beautiful for situation, the joy of the whole earth, is Mount Zion," is what the Psalmist wrote as he looked out upon the Holy City, and so we feel to-day, as we look upon this man, that there is a beauty, a moral beauty, in that life, that is to us, and will remain to us, a joy forever.

In attempting to analyze this life, with a view of forming some estimate of it, there are several things to be taken into consideration, - the circumstances under which it began, the obstacles it had to contend with, and what it became.

As to the circumstances under which he was born. These may be briefly set forth in two statements, - ( I) He was born a colored man; he was identified with a despised race,- - a race that had no rights which white men were bound to respect. The condition of the colored people in this country, - even the free colored people, - eighty years ago, was sad, inexpressibly sad. There was not even a glimmer of light on the horizon. All was dark, gloomy, and discouraging. (2) He was born a slave, a piece of property, a chattel, a thing to be bought and sold, to be cuffed and kicked about at the will of another.

The fundamental assumption underlying the system of slavery was the supposed inferiority of the negro, - the natural, inherent, God-ordained inferiority. Its great aim was to crush out of him every noble aspiration, to degrade him to the 
level of the brute, and make him a mere beast of burden. Hence it made it a crime for him to learn to read and write, almost to think. He was to have no views or opinions of his own. He was simply to reflect those of others, to be obedient to the mandates of the master. Its whole code of ethics was summed up in the injunction, "Servants, obey your masters." This man was born under this accursed system, a system which entirely ignored the fact that he was a man, or that he had the right to exercise any of the prerogatives of a man. This was not only the prevailing sentiment in the South, it was largely the prevailing sentiment in the North. Church and state were alike in league with the South against the negro. Almost the entire North was pro-slavery. It was worth almost a man's life to say a word against the slave power. It was in Boston, the Cradle of Liberty, that Garrison was dragged through the streets by a "broadcloth mob." It was in the state of Connecticut that Prudence Crandall's school was destroyed because she dared to admit colored pupils. What Theodore Parker said in his great scrmon, entitled "The True Idea of a Christian Church," perfectly reflects the then existing sentiment of the North: "Are there not three million brothers of yours and mine in bondage here, the hopeless sufferers of a savage doom; debarred 
from the civilization of our age, the barbarians of the nineteenth century; shut out from the pretended religion of Christendom, the heathens of a Christian land; chained down from the lib. erty unalienable in man, the slaves of a Christian republic? Does not a cry of indignation ring out from every legislature in the North; does not the press war with its million throats, and a voice of indignation go up from East and West, out from the hearts of freemen? Oh, no! There is none of that cry against the mightiest $\sin$ of this age. The rock of Plymouth, sanctified by the feet which led a nation's way to freedom's large estate, provokes no more voice than the rottenest stone in all the mountains of the IVest. The few that speak a manly word for truth and everlasting right are called fanatics; bid be still, lest they spoil the market. Great God! and has it come to this, that men are silent over such a sin? 'Tis even so. Then it must be that every' church which dares assume the name of Christ, that dearest name to men, thunders and lightens on this hideous wrong. That is not so. 'The church is dumb, while the state is only silent; while the servants of the people are only asleep, "God's ministers ' are dead."

Such were the conditions under which this man was born, and such were the adverse circumstances against which he had to contend. 
In looking back over this life, in studying it carefully, as he himself has written it out, the first thing that impresses us, and that gives promise that something may yet come out of it, is his rebellion against this system under which he was born. It asserted his inferiority, it declared that he was created simply for the convenience and the pleasure of others. This, in his inmost soul, he branded as a lie. Slave though he was, there came welling up into his soul the conviction that he was a man. And with that conviction its necessary corollary, that, being a man, he ought to be free. Byron, in his Prisoner of Chillon, speaks of the "eternal spirit of the chainless mind," and it was this spirit that came into his soul, and that came there never, never to be extinguished. The consciousness, I am a man, I ought to be free, are the first two steps in the progress of this life upwards.

A third step was soon taken, when he pleaded with his mistress for the privilege of learning to read, and by her assistance mastered the alphabet, thereby getting hold of the key which was to unlock to him the treasures of wisdom and knowledge. One of the most pathetic things in this history is the eagerness, the avidity, with which this little slave boy appropriated the crumbs of knowledge that lay about him. In imagination, I can see him now, with his spelling 
book concealed under his coat, pressing into his service his little white play fellows whom he met along the streets, as he was sent on errands or during his hours of play,-making them bis teachers. The spirit of liberty is not only stirring in this boy's breast, but a thirst for knowled is also taking possession of him. The immurtal mind, that marvelous thing we call the intellect, is beginning to work. The alphabet is soon mastered, the ability to read is soon acquired, and one book, at least, comes into his possession, the "Columbian Orator," from which he drank in great draughts of the bracing air of liberty, as he studied the utterances of such men as Chatham, Fox, Pitt, and others. Thus his idlas were enlarged and his desire to be free greatly stimulated. The truth of what his master had said to his mistress, when forbidding her to continue to instruct him, "Learning will do him no good, but a great deal of harm, making him disconsolate and unhappy," he began now keenly to realize: for he became more dissatisfied with his condition than ever.

In this frame of mind a fourth step soon followed-the solemn purpose and detemination to be free was formed. It was the natural and lugical outcome of what had gone before. I am a man. I ought to be free. I will be frece cinrison said, "I am in earnest. I will not cxucuse. 
I will not equivocate. I will not retreat a single inch, and I will be heard." And in the same spirit this man says, "I will be free." No emancipation proclamation, no stroke of the pen of the immortal Lincoln, gave freedom to him. He wrote his own emancipation proclamation; he struck with his own hands the fetters from his limbs. On the third day of September, $s_{j} \&$, he turned his back forever upon slavery and quietly settled down in the town of New Bedford, Massachusetts, where he labored, putting in coal, digging cellars, working on the wharves, and doing whatever he could get to do that was honorable, in order to make an honest living for himself and his family. Let our young people take note of that: it may give them a hint or suggestion that may be of service to them in the future. This man was not ashamed of work. It is hard for us to think of him as putting in coal, digging cellars, and working as a common laborer on the wharves; and yet he did, and was not ashamed of it either. All honest toil was honorable in his estimation. In his new environments, in order to keep from starving, it was necessary for him to work, and he did work, and work hard. He did not forget, however, in the midst of his struggles to keep soul and body together, that he also had a mind which needed to be fed. He still had a desire to 
improve himself, the old love for knowledge still burned within him. And hence all the leisure he could command he gave to the cultivation of his mind. He read books, and he read the newspapers, especially that great fountain head of antislavery thought and sentiment,-The Liborator. This paper he read carefuily, week by week, as it came out, with ever increasing interest and profit. And so things went on until I $8_{4}$ I, when quite unexpectedly to himself, and only three years after his escape from slavery, he loomed into notice, and then began that marvelous career which ended only two weeks ago last Wednesday. Incredible as it may seem, in the short space of nine years from his escape he was lecturing to great audiences, both in this country and in England, captivating them by the magic of his eloquence, and by his masterly appeals in behalf of his enslaved brethren, and was also the editor of a paper which took rank with such papers as The Liberator, The Anti-Slavery Siandard, and others. The most wonderful thing about it all is, not that he was able to talk to great audiences and edit a paper, but that he was able to do these things so well. Men heard him with astonishment, questioned, even doubted, the truth of his story, wondered whether his speeches and editorials were not written for him. It seemed incredible to them that he could ever 
have been a slave, or that he had so recently made his escape, or that he had had no educational advantages. Some said right out that they did not believe it. Either they must deny his story, or else admit that he was a prodigy. And this they were not ready to do. Even many who were disposed to be friendly were not quite prepared at that time to concede the possibility of a negro prodigy. Their doubts did not deter him, however. While they were puzzling their brains and philosophizing about him he moved steadily on. Day by day he continued to grow, to expand, to develop. More and more did he attract attention, and more and more did he make his infinence felt. It was not long before he won his way to the very front rank and took his place by the sicle of the greatest of the antislavery leaciers. Fifty-five years ago this man was unknown save to a few in the town of New Bedford. To-day he is linown everywhere. Fiftyfive years ago the name of Frederick Douglass was no more than any other name; to-day it is ne of earth's honored names. On Wednesday, licbruary 20, when he passed away, the whole civilized world took note of it, and acknowledged that one of earth's great men had fallen.

The Star of this city, in commenting on his death, says: "Of remarkable men this country has produced, at least, its quota, and among 
those whose title to eminence may not be disputed the figure of Frederick Douglass is properly conspicuous. Born into captivity and constrained for years by anti-educational environment he nevertheless achieved greatness such as rewards the conscientious efforts of but few."

The Philadelphia Press says: "The death of Frederick Douglass has been followed by wide public notice of the honors he has received, the consideration with which he has been treated, and the positions he has filled. But it is worth while remembering, in the interest of justice and equality,-twin duties of the Republic,- that these honors and this consideration were both infinitely less than he would have received in any other civilized country in the world."

An ex-editor in the Philadelphia Inquiversays: "That the whirligig of time brings its revenges was never better illustrated than in the death columns of the newspapers yesterday. In one chimn imposing headlines announced the demise of Frederick Douglass, ex-slare, of Talbot county, Maryland. In another two lines served to chronicle the death of the last Charles Carroll of Carroilton. The latter inherited great wealth and a proud name in American amals. The other was born a piece of animated chattels, without a name, taking the proud one of the master that owned him, and afterwards discarcing it 
for that of Douglass, with a double 's.' The one came from an ancestor who signed the Declaration of Independence. The other left children and grandchildren who are proud to claim him as an ancestor who helped to make possible the Proclamation of Emancipation. These are our two great charters of liberty. When history makes its final award it will not give a higher place to Charles Carroll of Carrollton, for that Magna Charta that left the black man enslaved, than to Frederick Douglass for the labors of a lifetime in securing that other, which washed out the blot in the 'scutcheon of the nation. It was an unconscious realization of the platitude of the Declaration of Independence, that all men are created equal, so long a mockery where all men were not free, that the newspapers should almost overlook the descendant of the 'signer' in paying an obituary tribute to the slave-born hero, who earned a renown greater than ancestry ever conferred."

The Philadelphia Record says: "Frederick Douglass was the most famous citizen of Washington. No other Washingtonian, white or black, has the world-wide reputation that he had. Indeed, when you stop to think of it, it would be difficult to name any other man, white or black, in the whole country who would be as well known as Frederick Douglass in every corner of the 


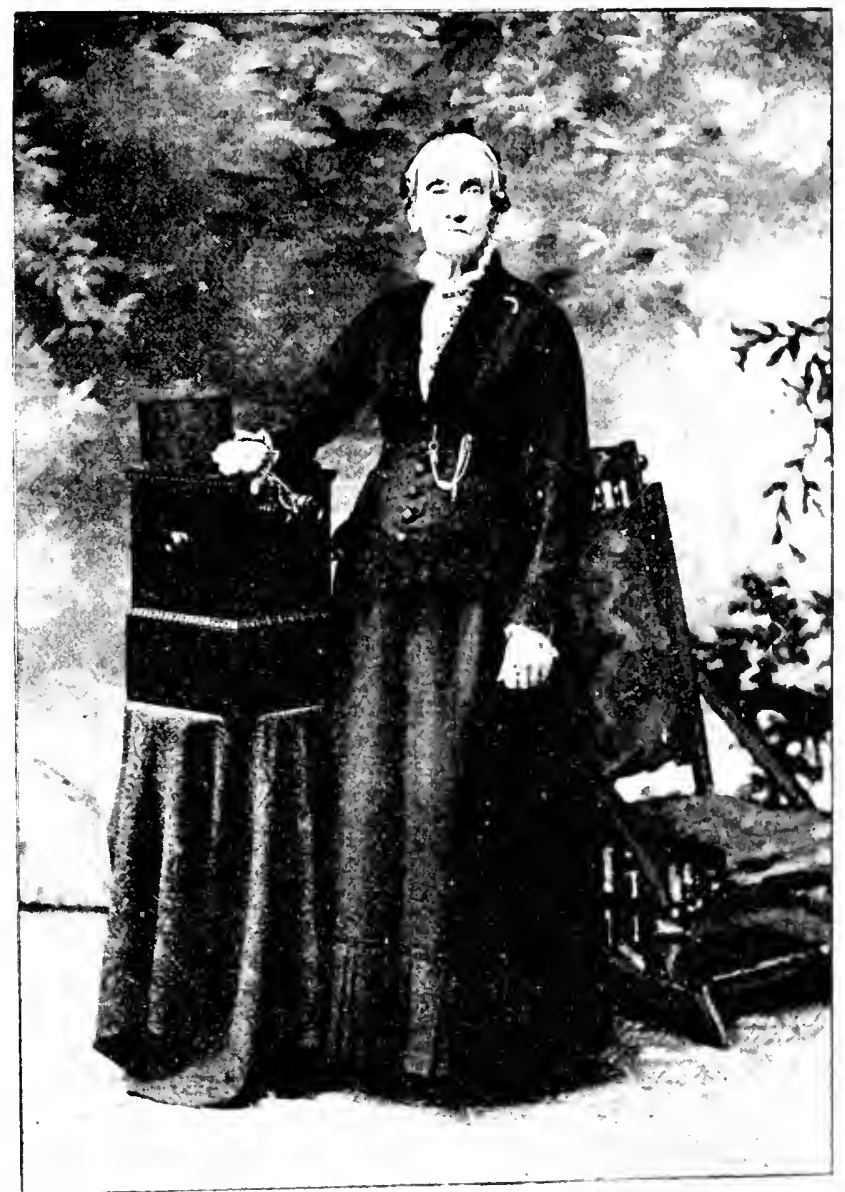

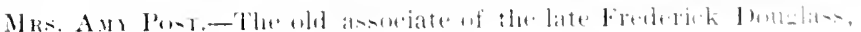

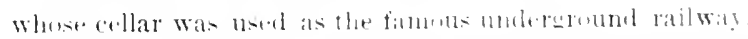




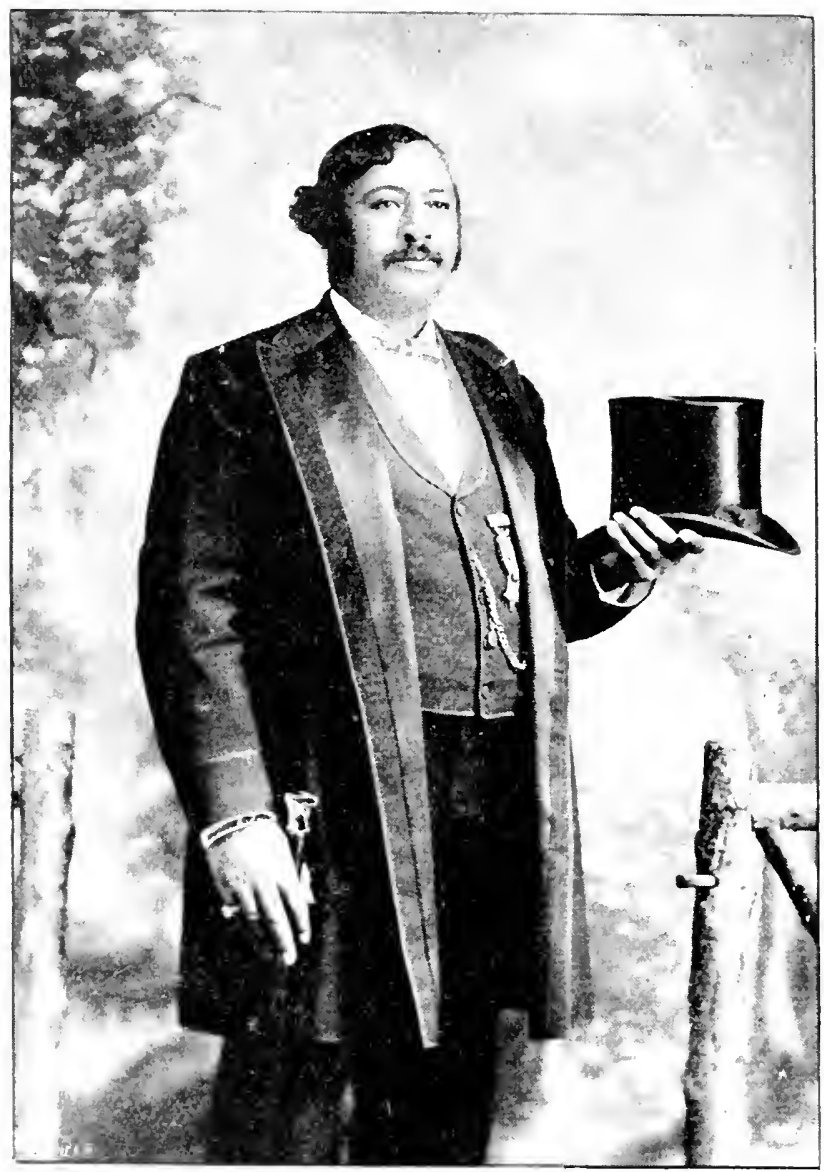

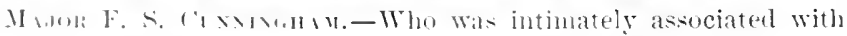

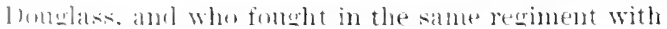
the dead statesmints soms. 
world. Lincoln and Grant were such men, but I cannot think of anyone now, except President Cleveland and ex-President Harrison, who are ex officio, so to speak, our world-wide celebrities. Dr. Holmes was the last of our men of letters who had this world-wide fame, and no other class of men or of women seems to have produced an international character in our time. Our great lawyers are perhaps known by lawyers the world over; our great physicians by physicians, clergymen by clergymen, journalists by journalists, business men by business men, and so on; but where is the man or woman who is known in all countries by people of all classes?" These are but samples of the many comments which his death called forth.

There have been other men in the history of our country who have risen from humble beginnings to places of power and influence. Lincoln was a rail splitter, Grant was a tanner, Garfield was a canal driver. These men had no such obstacles to overcome, however, as this man had. They were not identified with a despised race. They were not born slaves. Public sentiment was not against them. The schools and colleges of the land were not closed to them. Every arenue was open to them. In his case, however, the very reverse was true. And yet, in spite of his environments, with everything to discourage 
him, with obstacles like mountains rising before him at every step, by the sheer force of his character, by almost superhuman efforts,-for it seems almost like a miracle now as we look back over that life,-

"On with toil of heart and knees and hands, Through the long gorge to the far light he won His way upward,"

to a place by their side. And there he stands and will stand; not by sufferance, either, but by right. Indeed, in view of all the circumstances, when we remember where he began and where he ended, what his environments were, and what he became, he is, it seems to me, the most conspicuous and shining example of the century of what ability, and pluck, and character, and hard work can do to carve out a great and honorable career, in spite of adverse circumstances. His example stands colossal, to borrow an expression from Tennyson, yes, that is the only word that expresses it, colossal.

Notice in the second place, if you please, the debt we owe this man. Why should we, as a race, honor the memory of Frederick Douglass? What has he been to us? What has he done for us? It is impossible fully to estimate his services; nor shall I attempt in the limited time that is at my command this morning to do so. A few things may be said, however, that will 
enable us, in a measure at least, to approximate the greatness of these services.

In the first place, he consecrated to the welfare of this race, his splendid oratory. Whothat ever heard him can ever forget? Which of us has not felt the thrill of his magnetic utterances? And they tell us that he was nothing in his later days to what he used to be in the prime of his splendid manhood. This tongue of ficry eloquence he gave to this race; and who can estimate the influence of that voice as it rang out in every part of this country, in behalf of his oppressed and enslaved brethren? Wherever he went he attracted great audiences. In 1852 , at a meeting in one of the large halls in Philadelphia, he spoke for two hours to an audience which filled every seat, and packed the aisles. Ten o'clock came, and he stopped, amid cries of "Go on, go on." He stopped and said, "I don't often have the chance to talk to such an audience of friends. You who are standing are certainly wearied. We will take a five minutes recess, and allow anyone to retire who wishes to do so." "The time was up, and he spoke for another hour and a quarter, and not a man or woman left. Three hours and a quarter is a long time to sit and listen, much more to stand, and yet such was the power of his eloquence, that men forgot that they were standing, and ceased to take note of the time. 
A writer in the New York Evangelist describes a scene which took place in that city, and which will give us some idea of what the effect of this man was, as he went from place to place, a living protest against the barbarism of slavery. $\mathrm{He}$ says: "When Anthony Burns was taken by slave hunters in the streets of Boston, and Dred Scott was handed over in Missouri to his captors by a Supreme Court decision, the end of forbearance had come, the limit of endurance was passed, the slave power had humiliated the nation. In those days it was necessary for politicians to 'trim ship' with extraordinary vigilance and adroitness. To them Douglass seemed a specter of defeat. If he lifted those once manacled arms before the people, even before they caught the tremulous tones of his magical voice, they were swayed by uncontrollable emotion. Once in the old Broadway Tabernacle, filled up to the dome, as Douglass was announced, the vast crowd sprang up as one man, and the Marseillaise Hymn, with a refrain, 'Free soil, free speech, free press, free men,' rolled out through doors and windows, blocking the street with lingering listeners for a hundred yards either way. Meanwhile Douglass stood with bowed head, great tears coursing down his cheels." His very presence was often more effective than the eloquence of other men.

In the sccond place, he consecrated to the serv. 
ice of his race his time and all the powers of his body and mind. He labored incessantly. He was instant in season and out of season. He worked by day and by night. He was at it, and always at it. The wonder is that his iron constitution did not give way. He, himself, tells us that he used to write all day, and then take the train and go off at night and speak, returning the same evening, or early the next morning, only to resume his work at his desk.

In addition to writing and speaking, he was also an active agent in the Underground Railroad, and from his house many a fugitive crossed the line into Canada. He labored also in many other ways.

Some men have said Douglass was selfish, that he always had an eye to his own interest, implying that it was not the race that he was thinking of so much as himself. For this base insinuation, for that is the only term which properly characterizes it, I have only the utmost contempt. When I think of how richly this man was endowed, of the great services which he rendered to freedom, and remember that his salary was only four hundred and fifty dollars a year; when I think of his self-sacrificing efforts to carry on his paper, The Vorth Star. putting every cent that he could into it, eren mortgaging the house over his head, I say I do not believe it. I have 
read his life carefully and I have had the honor of knowing him intimately for a number of years, and, as I look back over those years, I can recalı nothing that would in any way justify such an accusation. In the summary which he gives at the close of Part Second of his life, we get a true insight into the spirit which animated him during his long and eventful life, as well as the motives which prompted him to make a record of that life. He says: "It will be seen in these pages that I have lived several lives in one: first, the life of slavery; secondly, the life of a fugitive from slavery; thirdly, the life of comparative freedom; fourthly, the life of conflict and battle; fifthly, the life of victory, if not complete, at least assured. To those who have suffered in slavery I can say, I, too, have suffered. To those who have taken some risks and encountered hardships in the flight from bondage I can say, I, too, have endured and risked. To those who have battled for liberty, brotherhood, and citizenship I can say, I, too, have battled. And to those who have lived to enjoy the fruits of victory I can say, I, too, live and rejoice. If I have pushed my example too prominently for the good taste of my Caucasian readers, I beg them to remember, that I have written in part for the encouragement of a class whose aspirations need the stimulus of success. "I have aimed to show them that knowledge 


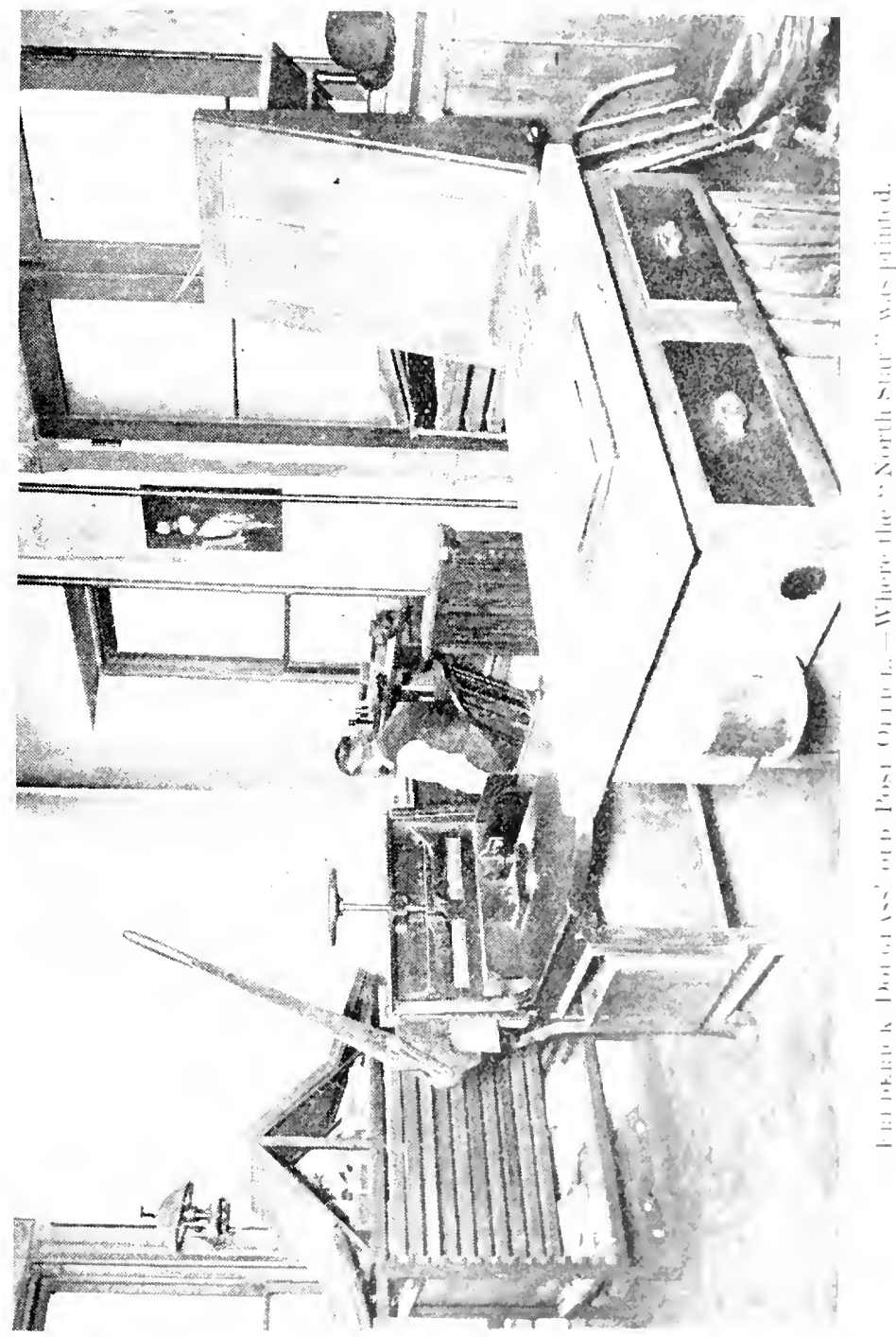




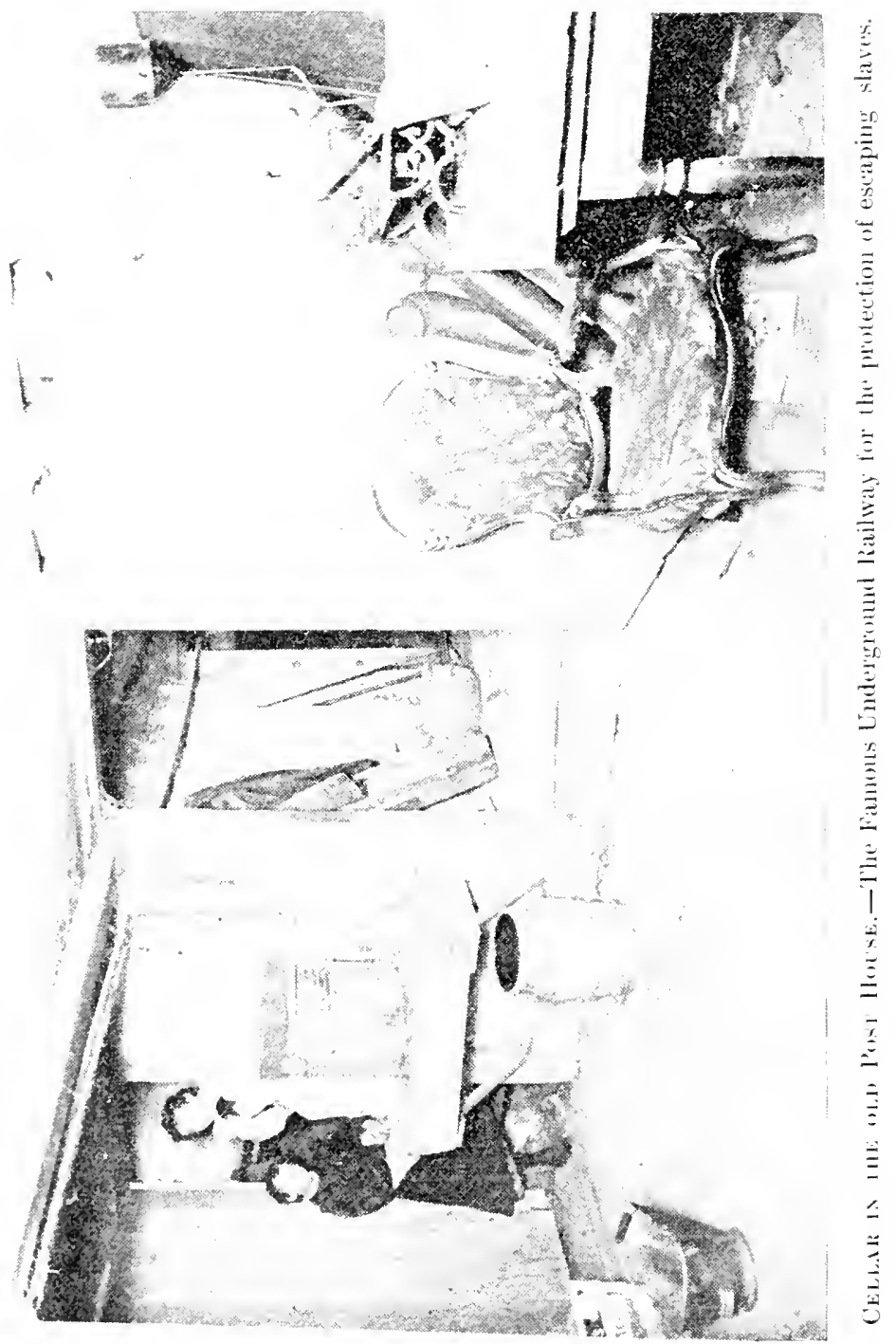


can be obtained under difficulties; that poverty may give place to competency; that obscurity is not an absolute bar to distinction, and that a way is open to welfare and happiness to all who will resclutely and wisely pursue that way; that neither slavery, stripes, imprisonment, nor proscription need extinguish self-respect, crush manly ambition, or paralyze effort; that no power outside of himself can prevent a man from sustaining an honorable character and a useful relation to his day and generation; that neither institutions nor friends can make a race to stand unless it has strength in its own legs; that there is no power in the world that can be relied upon to help the weak against the strong, or the simple against the wise; that races, like individuals, must stand or fall by their own merits. I have urged upon them self-reliance, self-respect, industry, perseverance, and economy. Forty years of my life have been given to the cause of my people, and if I had forty years more they should all be sacredly given to the same great cause." There is not a taint of selfishness there. If any man ever lived who carried this race upon his heart, who desired to see it succeed. and who labored earnestly for its freedom, for its clevation, for its protection under the laws, and in order that it might have a fair chance in the race of life, that man was Frederick Douglass. He lored 
this race with all the depth and strength of his great soul. One of the most touching things I ever heard of him was told me by a friend. $\mathrm{He}$ happened to call at the house while Mr. Douglass was preparing his great speech on Southern Outrages. He took this friend into his study and read portions of that speech, and when he came to the part which described the sufferings of our poor brethren in the South, great strong man though he was, the tears ran down his cheeks and choked his utterance so that he was unable to proceed. Tell me that this man was selfish, that he was thinking only of himself! It will be a long time before this black race will have another Douglass to lean upon, a long time before it will find another man to carry it in his heart of hearts as he did. "Forty years of my life I have given to the cause of my people, and if I had forty more they should be all sacredly given to the same great cause," is not the utterance of selfishness, but of a great soul whose chief desire was the good of his people. As the exiled Jews felt towards the Holy City, "If I forget thee, O Jerusalem, let my right hand forget her cunning. If I do not remember thee, let my tongue cleave to the roof of my mouth, if I prefer not Jerusalem above my chief joy," so felt he towards this race. It was ever uppermost in his thoughts; and never did he forget it for a moment. 
In the third place, it was due largely to the influence of Mr. Douglass, that the colored man was allowed to shoulder his musket and strike a blow for his own freedom and for the preservation of the Union. In Chapter Eleventh of his Life, entitled, "Secession and War," he says: "When the government persistently refused to employ colored troops; when the emancipation proclamation of General John C. Fremont, in Missouri, was withdrawn; when slaves were being returned from our lines to their masters; when Union soldiers were stationed about the farmhouses of Virginia to guard and protect the master in holding his slaves; when Union soldiers made themselves more active in kicking colored men out of their camps than in shooting rebels; when even Mr. Lincoln could tell the poor negro that 'he was the cause of the war;'-I still believed, and spoke as I believed, all over the North, that the mission of the war was the liberation of the slave, as well as the salvation of the Union; and hence from the first I reproached the North that they fought the rebels with only one hand, when they might strike effectually with two,- that they fought with their soft white hand, while they kept their black iron hand chained and helpless behind them, - that they fought the effect, while they protected the cause, and that the Union cause would never prosper 
till the war assumed an antislavery attitude and the negro was enlisted on the loyal side. In every way possible,-in the columns of my paper, and on the platform, in my letters to friends at home and abroad,-I did all that I could to impress my conviction upon this country."

And when the general government finally came to its senses, and Governor Andrew of Massachusetts was given permission to raise two colored regiments, it was through the columns of his paper that the cry rang out, "Men of color, to arms, to arms!" It was his pen that wrote the burning words, "Liberty won by white men would lose half its luster. Who would be free, themselves must strike the blow." "Better even die free than to live slaves." "By every consideration which binds you to your enslaved feliow-countrymen and to the peace and welfare of your country; by every aspiration which you cherish for the freedom and equality of yourselves and your chilchen; by all the ties of blood and identity which make us one with the brave black men row fighting our battles in Louisiana and in South Carolina,- I urge you to fiy to arms, and smite with death the power that would bury the government and your liberty in the same hopeless grave." He also took a very active interest in securing just and fair treatment for the colored soldicr, after his services were accepted. To this 
end he not only wrote and spoke, but visited Washington, and had an interview with President Lincoln and Secretary Stanton, in which he urged " the right of the colored soldiers to receive the same wages as the white soldiers; the right of the colored soldier to receive the same protection when taken prisoner, and be exchanged as readily and on the same terms as any other prisoner; that if Jefferson Davis should shoot or hang colored soldiers in cold blood, the United States Government should without delay retaliate in kind and degree upon Confederate prisoners in its hands; and that when colored soldiers performed great and uncommon services on the battlefield, they should be rewarded by distinctions and promotions precisely as white soldiers are rewarded for like services." And he never ceased to press this matter upon the attention of those in authority until the end he aimed at was accomplished.

In the fourth place, he rendered also most important services in bringing about the enfranchisement of the race. Even Mr. Garrison and other antislavery leaders questioned, at first, the wisdom of such a step, but this man never doubted, never hesitated. To him suffrage was necessary to enable the negro to protect himself, and hence to it he addressed himself with all the earnestness of his nature, using all the means 
within his power to secure it for him. "From the first," he says, "I saw no chance of bettering the condition of the freedman until he should cease to be merely a freedman, and should become a citizen. I insisted that there was no safety for him nor for anybody else in America outside the American government; that to guard, protect, and maintain his liberty the freedman should have the ballot; that the liberties of the American people were dependent upon the ballot-box, the jury-box, and the cartridge-box; that without these no class of people could live and flourish in this country; and this was now the word for the hour with me, and the word to which the people of the North willingly listened when I spoke. Hence, regarding as I did the elective franchise as the one great power by which all civil rights are obtained, enjoyed, and maintained under our form of government, and the one without which freedom to any class is delusive, if not impossible, I set myself to work with whatever force and energy I possessed to secure this power for the recently emancipated millions." With this end in view, in company with other gentlemen, he brought the matter to the attention of President Johnson, and the next morning published a letter which was very widely commented upon, and which had the effect of bringing the subject prominently before the conntry. He also 
spoke very earnestly before the National Loyalists' convention which met in Philadelphia in September, 1865. He also labored personally with many senators when the matter was before that body, visiting them daily, and pressing upon them the necessity and the justice of the measure. And so he continued to work until he had the satisfaction of seeing it enacted into law, in the form of the Fifteenth Amendment to the Constitution.

There are many other things that might be mentioned under the general head which we are consiclering, but the time will not permit. Suffice it to say, that during the last half century there has been no measure looking to the betterment of our condition as a people in this country in which he has not been a leading actor. For more than fifty years he has allowed no opportunity to pass unimproved in which, either by his voice or pen, he could make the way easier and the future brighter for this race. Whenever we have needed a defender, he has always been on hand. Whenever there were rights to be asserted, he has always stood ready to make the demand, never laggsing behind, always at the front. For more than fifty years he has stood as a sentinel on the watch-tower, guarding with the most jealous care the interests of this race. I remember when he was appointed minister to 
Hayti. I did not want him to go; I wrote him and told him so, and told him why. It was because I felt that we could not spare him out of the country. It seemed to me that our interests would not be quite so safe if he were away. The very fact that he was here filled me with the assurance that all would be well. And this is the way, I think, we all felt,-a sense of security in the consciousness of the fact that he was in our midst.

In politics he was a Republican. He loved the grand old party of Liberty, - but when it proved recreant to its trust, when it was ready to sacrifice the negro, to trample him in the dust, to push him aside out of deference to popular prejudice, then it was that he turned upon it, and cauterized it with actual lightning. I shall never forget the article which he wrote on the reasons for the defeat of the Republican party, which was published, I think, in Harper's Hcckly. It was a masterly arraignment of that party for its cowardice and its perfidy, and showed how deeply concerned he was for the welfare of this race, and how he was ever looking out for its interests. In the twenty-fifth chapter of the Gospel of Matthew, Jesus is represented, in the great day of solemn account, as saying to those on his right hand, "Come, ye blessed of my Father, inherit the kingdom prepared for you 
from the foundation of the world: for I was an hungered, and ye gave me meat: I was thirsty, and ye gave me drink: I was a stranger, and ye took me in: naked, and ye clothed me: I was sick, and ye visited me: I was in prison, and ye came unto me." And this is what we can all say to-day, as a race, as we think of this man. He has been all that is here implied to us. In our distress and suffering, in our hours of loneliness and despondency, when we have felt discouraged and sick at heart, he has stood by us, and watchecl over us, and ministered to our necessities. and cheered us by his voice and presence. What is it that he hasn't done? In what way has he not manifested his interest? What more could he have done than he has done?

There are many other things that I should like to speak of had I the time. I should like to speak of some of his personal traits and characteristics; of his gentleness, his sympathetic nature, his tenderness, his generosity, his great-heartedness.

There was nothing mean, or close-fisted, or penurious about him. God blessed him with means, and he used it for the glory of his Naker, and the good of his fellow-men. He was all the time giving to some good cause, or reaching out a hand to help the needy. We went to him when we started the movement for the purchase 
of the building on Eleventh street, for the use of the Young Men's Christian Association, which was made necessary because black men were shut out of the one on New York avenue, -let it be said to its shame; I never pass that building and look up at the name inscribed upon it,- "Christian Association," - without feeling that it is a libel upon the holy religion of Jesus Christ. As well write it over the portals of perdition, as there, and expect me to believe it. It is a lie. The great man whom we honor to-day utterly loathed the spirit which made such a lie possible, and which, years ago, nearly drove, and to-day is driving, some of our most gifted men into infidelity. If there is any Christianity there, it is a spurious Christianity. It is not the Chrisrianity of the Bible. There was no color-phobia in Christ; and there is none in Christianity, whatever may be the practice of so-called Christian men and women.

When we were making arrangements to purchase the building on Eleventh street, as I have said, in company with the International Secretary, Mr. Hunton, we called upon Mr. Douglass, and laid the matter before him. He listened to us, and when we were through said, "Gentlemen, I am not a rich man,-I can't give you as large a subscription as I would like to give, but I will give something. Put me down for two hundred dol- 
lars." And that is but a sample of what he was constantly doing.

Many years ago, in the city of Baltimore, before he made his escape from slavery, while he was working in one of the ship-yards, he was set upon by some of the white laborers, mobbed, dreadfuily beaten, and came very near losing his life. The cry was, "Kill the nigger." Among those who took up that cry, and who tried very hard to kill him, was a man who up to a short time ago was still living in Baltimore. He was then old, decrepit, sick and in great destitution. Mr. Douglass heard of it, called upon him, spoke kindly to him, and in parting left a ten dollar bill in his hand. It was a beautiful thing for him to do. It was a noble thing, and it was just like him. He was all the time doing noble things. God bless his memory, and give us more men like him!

I might also speak of his love of the beautiful, in art and in nature. At the great Columbian Exposition, the Art Gallery was a constant delight to him. He reveled in its treasures. And how he loved all nature,-the flowers, and the grass, and the trees, and the birds, and the drifting clouds, and the blue sky, and the stars; he had a poet's love for nature. With Wordsworth he could say,-

"To me the meanest flower that blows can give Thoughts that do often lie too deep for tears." 20 
How often have I heard him speak, as I have sat with him on the front porch of his beautiful home, or under the trees on the hill-side, with the lovely landscape stretching out on all sides around us, - of the pleasure which it gave him, the satisfaction, how it rested him to commune with nature.

I might also speak of his love of music,-his passionate love of music,-especially the music of the violin. He had a kind of reverence for that instrument. It seemed to him almost like a living thing. How lovingly he handled it! With what enthusiasm he spoke of it! He could hardly resist the temptation of speaking to a man who carried a violin. He used to say, "No man can be an enemy of mine who loves the violin." $\mathrm{He}$ never missed an opportunity of hearing a great violinist. He heard them all. It was his favorite instrument. Not even Paganini himself had a more passionate love for it. He delighted also in vocal music, especially in sacred music,-in the old hymns of Zion that breathe the sentiment of love, of trust, and of hope. One of his favorite hymns was "Jesus my Saviour to Bethlehem Came," with the refrain, "Seeking for Me."

"Oh, it was wonderful, blest be His name, Seeking for me, for me."

Another was 
"In thy cleft, O Rock of Ages,

Hide thou me,

When the fitful tempest rages,

Hide thou me.

Where no mortal arm can sever

From my heart thy love forever,

Hide me, O thou Rock of Ages, Safe in thee."

That hymn I shall never forget. The last time it was my privilege to be at his house, only a few weeks before he passed away, after dinner was over we all repaired to the sitting room, and he himself suggested that we should have some music. His grandson Joseph was there, and we knew therefore that there was a rich treat in store for us. We had music on the piano, and music on the violin, and singing. In the singing he was the principal figure. Standing in the doorway, between the sitting-room and the hall, with violin in hand, he struck up the last mentioned hymn, "In thy cleft, O Rock of Ages," and sang it through to the very end, with a pathos that moved us all. We all spoke of it afterwards. It seemed to take hold of him so. The closing lines, especially, seemed to touch the great deeps of his nature. I can almost hear now the deep mellow tones of that voice, and feel the solemnity that pervaded the room as he sang the words,-

"In the sight of Jordan's billow,

Let thy bosom be my pillow,

Hide me, $\mathrm{O}$ thou Rock of Ages,

Safe in thee," 
as if he had a kind of presentiment that the end was near,- - that he was already standing on the very brink of that Jordan over which he has since passed, and over which, one by one, we shall all pass. The prayer which he uttered that night,-

"Let thy bosom be my pillow,

Hide me, O thou Rock of Ages,

Safe in thee,"

1 believe, has been answered. His noble head was pillowed, I believe, on the bosom of the "Strong Son of God," when he fell asleep in death, and that he is safe in Him.

It is hard to realize that he is no longer among us; that we shall no longer see his noble form, nor hear his eloquent voice, nor receive from him the gracious benediction of that radiant smile, which so often played upon his face.

$\mathrm{He}$ is gone, but the memory of his great deeds remains. Never can we forget him. Never can we cease to hold him in grateful remembrance. What he was, and what he did, will remain to us forever, a joy and an inspiration.

"Mourn for the man of amplest influence

Yet clearest of ambitious crime,

Our greatest, yet with least pretense,

Rich in saving common sense,

And as the greatest only are

In his simplicity sublime.

O good gray head which all men knew,

$O$ voice, from which their omens all men drew,

$\mathrm{O}$ iron nerve to true occasion true, 
$O$ fall'n at length that tower of strength

Which stood foursquare to all the winds that blew."

To those of us who are members of the race with which he was identified, let me say, let us keep his shining example ever before us. Let each one of us, individually and personally, endeavor to catch his noble spirit, to walk upon the same lofty plane of a pure and exalted manhood upon which he moved; and together, in the consciousness of the fact that he is no longer with us, let us consecrate ourselves, with whatever powers we may possess, to the furtherance of the great cause to which he gave his life.

And may I not also, in his name, appeal to the members of the opposite race, especially to those who revere his memory, to join with us in continuing to fight for the great principles for which he contended, until in all sections of this fair land there shall be equal opportunities for all, irrespective of race, color, or previous condition of servitude ; until, to borrow the language of another, "character, not color, shall stamp the man and woman," and until black and white shall clasp friendly hands, in the consciousness of the fact that we are all brethren and that God is the Father of us all. 




